\title{
The Decline of the Virginia (and American) Death Penalty
}

\author{
Brandon L. GarRetT*
}

The American death penalty is disappearing. Death sentences and executions have reached the lowest levels seen in three decades. Even the states formerly most aggressive in pursuit of death sentences have seen death sentences steadily decline. Take Virginia, which has the highest rate of executions of any death penalty state, and which has executed the third highest number of prisoners since the 1970s. How times have changed. There has not been a new death sentence in Virginia since 2011. Only seven counties have imposed death sentences in the past decade in Virginia. There are now two or fewer trials a year at which a judge or jury considers imposing the death penalty. Still more surprising, at over one half of those trials the judge or jury chooses a sentence of life without parole (eleven of twenty-one cases from 2005 to 2015 at which there was a capital sentencing hearing resulted in a life sentence). Why is this happening-and in Virginia of all places? In this study, I examine every capital trial from 2005 to 2015-twenty-one trials-and I compare a group of twenty capital trials from 1996 to 2004. The law on the books has not meaningfully changed. However, in 2004, the legislature created regional defense resource centers to handle capital cases. From 1996 to 2004, the crucial sentencing phase, at which the judge or jury decided whether to impose the death penalty, was typically cursory, averaging less than two days long. In the more recent trials, the average was twice that-four days-and still more striking was the increase in the numbers of defense witnesses called, the greater use of expert witnesses, and the added complexity of sentencing proceedings. Improved capital defense resources may explain this sharp and sudden decline in death sentences. North Carolina, which created a similar state capital defense resource office, experienced a decline that tracks Virginia's, and yet in states like Florida, lacking statewide defense resources, the rate with which death sentences are imposed has remained fairly stable. This evidence: (1) raises heightened Eighth Amendment arbitrariness concerns with the scattered state of the

* Justice Thurgood Marshall Distinguished Professor of Law, University of Virginia School of Law. (C) 2017, Brandon L. Garrett. Many thanks to Michele Brace, Stephen Bright, David Bruck, John Douglass, Elizabeth Hambourger, Valerie Hans, Rob Lee, Saul Lehrfruend, John Monahan, Rob Smith, Scott Sundby, Keir Weyble, Edward Ungvarsky, Ethan Yale and participants at faculty workshops at Cornell Law School, University of Richmond School of Law, Warwick University School of Law, as well as talks at the University of Virginia School of Law and at the Death Penalty Project in London, for their invaluable comments on earlier drafts. I particularly thank David Bruck and the Virginia Capital Case Clearinghouse for sharing invaluable data; Rob Lee and the Virginia Capital Resource Center, as well as the other lawyers and court clerks who assisted in locating and sharing trial materials; Kent Olson from the University of Virginia law library for helping to locate trial materials, and a grant from the Proteus Action League for making purchase of not-previously-transcribed trials possible. I thank Ankur Desai, Alex Haden, John McGlothlin, Jack Shirley, Elaine Singerman, and Rachel Wester for their superlative research assistance. 
American death penalty, including that death sentences may result from local failures to provide adequate defense resources; (2) demonstrates that those same failures implicate Sixth Amendment ineffective assistance of counsel claims in individual cases and in systematic challenges in states that fail to provide adequate resources; and (3) strongly supports the establishment of statewide capital-and non-capital-public defender offices.

TABle of Contents

INTRODUCTION

I. The Virginia Death Penalty . . . . . . . . . . . . . . 670

A. THE HEYDAY OF THE VIRGINIA DEATH PENALTY . . . . . . . 670

B. THE LEGAL STRUCTURE OF THE VIRGINIA DEATH PENALTY . . . . 671

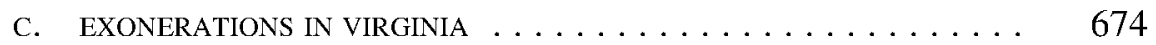

D. CAPITAL REPRESENTATION $\ldots \ldots \ldots \ldots \ldots \ldots \ldots$

II. Findings: Virginia Capital Trials from 2005-2015 . . . . . . . 679

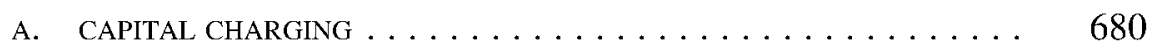

B. GUILT PHASE EVIDENCE IN VIRGINIA . . . . . . . . . . . . 683

1. Innocence Defenses . . . . . . . . . . . . . 685

2. Self-Defense and Additional Defenses $\ldots \ldots \ldots \ldots 66$

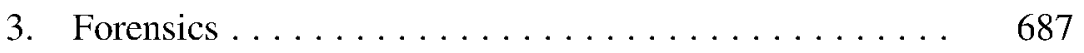

4. Confessions .................... 688

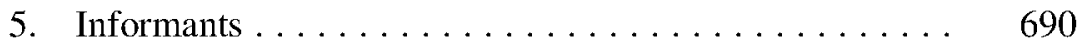

6. Eyewitnesses . . . . . . . . . . . . . 691

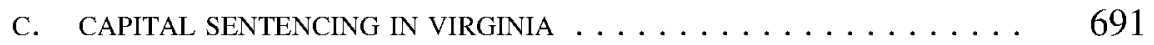

1. Data on Recent Capital Trials . . . . . . . . . . 693

2. Mental Illness . . . . . . . . . . . . 696

3. Intellectual Disability . . . . . . . . . . . . 698

4. Background Evidence $\ldots \ldots \ldots \ldots \ldots \ldots \ldots$

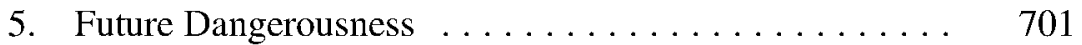

6. Vileness $\ldots \ldots \ldots \ldots \ldots \ldots \ldots \ldots \ldots \ldots$

7. Victim Statements . . . . . . . . . . 706

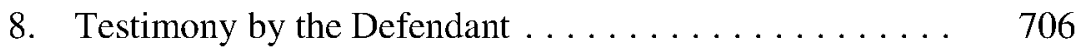


III. Virginia Capital Trials from 1996-2004 . . . . . . . . . . 707

A. CHARACTERISTICS OF THE PRE-2005 TRIALS . . . . . . . . . 709

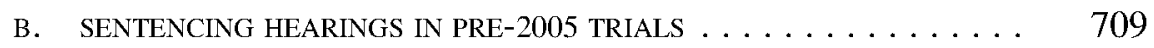

IV. The Virginia and the American Death Penalty Decline . . . . . 714

A. PUBLIC OPINION, COST, GEOGRAPHY, AND CRIME RATES . . . . . . 715

B. THE DECLINING DEATH PENALTY IN NORTH CAROLINA . . . . . . 720

C. THE FLORIDA COUNTEREXAMPLE . . . . . . . . . . . . . 722

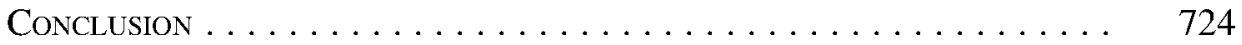

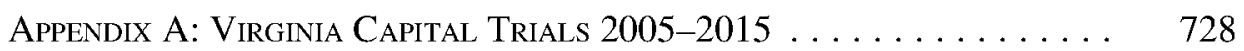

Appendix B: Twenty Virginia Capital Trials, 1994-2004 . . . . . . 729

\section{INTRODUCTION}

The American death penalty is disappearing. Executions have reached the lowest levels seen in decades. ${ }^{1}$ Public support for the death penalty has declined. $^{2}$ More states have abolished the death penalty or imposed de facto moratoria. ${ }^{3}$ Even the states formerly most aggressive in pursuit of death sentences have seen death sentences steadily decline, and in 2015 and 2016, the United States experienced the lowest numbers of new death sentences imposed since $1973 .{ }^{4}$ A classic case in point is Virginia, which has the highest rate of

1. Mark Berman, How the Death Penalty Continued Its Slow, Steady Decline in 2014, WASH. PosT (Dec. 18, 2014), https:/www.washingtonpost.com/news/post-nation/wp/2014/12/18/how-the-deathpenalty-continued-its-slow-steady-decline-in-2014/?utm_term= .ccc6f6b51122 [https://perma.cc/5SGH6YR8] ("The United States executed 35 inmates in 2014, the smallest number in two decades. And the number of inmates sentenced to death is projected to be $72 \ldots$ which would be fewer than a quarter of the number of death sentences handed down in the mid-1990s."). This Article is part of a research project described in a forthcoming book examining the death penalty decline comprehensively and a forthcoming article presenting statistical analysis of county-level death sentencing. BRANDON L. GARRett, End of Its Rope: How Killing the Death Penalty Can Revive Criminal Justice (forthcoming, Harvard University Press); Brandon L. Garrett, Alexander Jakubow \& Ankur Desai, The American Death Penalty Decline, 105 J. Crim. L. \& Criminology (forthcoming 2017).

2. Alan Cooperman et al., Pew Research Ctr., Shrinking Majority of Americans Support Death PenAlTy 1 (2014).

3. Eighteen states have abolished the death penalty, and six of those states did so since 2007. Mark Berman \& Robert Barnes, Everything You Need to Know About Executions in the United States, WAsH. Post (May 1, 2014), https://www.washingtonpost.com/news/post-nation/wp/2014/05/01/everything-youneed-to-know-about-executions-in-the-united-states/?utm_term $=. f 395 \mathrm{ecb} 3 \mathrm{a} 2 \mathrm{~d} 8$ [https://perma.cc/ 5GC2-B9C2]. Washington is the most recent state to impose a moratorium. $I d$. Other states, like California, have not carried out executions in years for reasons including litigation regarding lethal injection protocols. See infra note 341.

4. I have hand-collected comprehensive data on death sentencing from 1991-present, that includes resentencing (which accounts for minor differences in the data reported from the Death Penalty Information Center (DPIC)); including persons resentenced to death, I have identified fifty-six death 
executions of any death penalty state, and which has executed the third highest number of prisoners since the $1970 \mathrm{~s}^{5}$ How times have changed. Almost all capital cases are plea bargained and there are now two or fewer trials a year in Virginia at which a judge or jury considers imposing the death penalty. Still more surprising, I have found that in the past decade, over one half of those Virginia trials resulted in a life sentence: eleven of twenty-one cases from 2005 to 2015 at which there was a capital sentencing hearing resulted in a life sentence. Just seven counties in Virginia imposed death sentences in that time period of eleven years. As Professor David Bruck has put it, capital punishment in Virginia "has largely ground to a halt," with just six individuals remaining on death row and no new death sentences imposed since $2011 .^{6}$

Why is this happening, and in Virginia of all places? This question is of practical relevance to death penalty litigators and observers of the death penalty, but it is also of constitutional relevance. In 2015, Justice Stephen Breyer, joined by Justice Ruth Bader Ginsburg, dissented from the Court's holding in Glossip v. Gross, and called for briefing regarding the question whether the current practice of the death penalty is categorically unconstitutional. ${ }^{7}$ Justice Breyer emphasized that the death penalty has "increasingly become unusual," having "declined rapidly" in the last fifteen years, raising heightened Eighth Amendment concerns. "Justice Breyer also noted the "dramatic declines" within states like Texas and Virginia and, with additional concerns about wrongful convictions, arbitrariness, and delays, he called for full briefing on whether the American death penalty violates the Eighth Amendment. ${ }^{9}$

In this study of the Virginia death penalty decline, I examine every capital trial from 2005 to 2015 , a group of twenty-one trials, by studying the trial transcripts themselves to examine what evidence was presented at both the guilt

sentences in 2015, of which fifty-one were new death sentences, including one federal case). Of the three death sentences in Texas in 2015, one was a resentencing, and that case was the only Harris County sentence in 2015. There were only thirty new death sentences in 2016. For a description of these data and statistical analysis, see Garrett, Jakubow \& Desai, supra note 1; see also Timothy Williams, Executions by States Fell in 2015, Report Says, N.Y. Times (Dec. 16, 2015), http://www. nytimes.com/2015/12/16/us/executions-by-states-fell-in-2015-report-says.html?_r=1 [http://nyti.ms/ 1P7glO2] (reporting DPIC data regarding death sentencing).

5. See Number of Executions by State and Region Since 1976, Death Penalty Info. Ctr. (last updated Oct. 19, 2016), http://www.deathpenaltyinfo.org/number-executions-state-and-region-1976 [https://perma.cc/7JHK-53A3]; see also David Garland, Peculiar Institution: America's Death PenALTY IN AN AGE OF Abolition 41 (2010) (noting that at the time of publication, Virginia had executed the second highest number of prisoners since the 1970s).

6. Larry O'Dell, Virginia's Death Row Population Down to 8, Assoclated Press (Mar. 8, 2013, 1:27 PM) http:/www.nbcwashington.com/news/local/Virginias-Death-Row-Population-Down-to-8-1962844 11.html [https://perma.cc/8LZZ-6VHS]; Virginia Executes Man Convicted of Slashing Throats of Couple, 2 Daughters, CHI. TRIBUNE (Jan. 18, 2017), http://www.chicagotribune.com/news/nationworld/ ct-virginia-execution-20170118-story.html [https://perma.cc/FDX3-BSFH].

7. See 135 S.Ct. 2726, 2772-76 (2015) (Breyer, J. dissenting).

8. Id at 2772-73.

9. Id. at 2775 . 
and sentencing phases. ${ }^{10}$ To better understand what has changed in the Virginia death penalty, I compare those trials to a group of twenty capital trials from 1996 to 2004, selected from the time period before the decline set in. ${ }^{11}$ I also examined data on capital charges filed in Virginia and the costs of appointed capital counsel, and I conducted interviews with counsel who litigated recent capital trials. One explanation for the steep decline could be that prosecutors have become less willing to seek the death penalty when they would formerly do so. Although prosecutors appear to file capital charges at a fairly steady rate, the vast majority of cases are now negotiated through plea bargains-without death sentences. Why does that occur? The law on the books has not meaningfully changed in ways that would make it harder to obtain death sentences, and Virginia lawmakers have long installed death-penalty-friendly procedures.

In 1994, Stephen Bright, President of the Southern Center for Human Rights, famously argued that the death penalty was imposed "not upon those who commit the worst crimes, but upon those who have the misfortune to be assigned the worst lawyers." ${ }^{\prime 2}$ The role of defense lawyering will be a focus of this Article. Bright vividly described how even lawyers who were totally incompetent-those who were asleep or intoxicated at trial or who referred to their clients using racial slurs-were routinely found acceptable in death penalty cases. ${ }^{13}$ Perhaps still more troubling than those horror stories, Bright explored the everyday structural features of indigent capital representation in many states, including minimal compensation for defense counsel, routine denial of resources for investigation or experts, and the lack of indigent defense systems generally, and offices that specialize in defending capital trials, specifically. ${ }^{14}$

In the years since Bright's article, the law has modestly improved. The United States Supreme Court intervened to regulate the performance of death penalty defense lawyers, in several decisions emphasizing the importance of adequate counsel, particularly at the sentencing phase (the first of which, Williams v. Taylor, was a Virginia case).$^{15}$ The Court's rulings followed changes in the standards for capital practice, with influential American Bar Association standards adopted in 1989 and revised in 2003, with supplemental guidelines

10. Appendix A lists each of these trials.

11. Appendix B lists each of these trials. I examined the entire set of trials from 2005 to 2015 because, as described in Section I.D., in 2004, Capital Resource Centers were created in Virginia, and I wanted to compare the effect of lawyering subsequent to the creation of those Centers with the lawyering in earlier capital trials. The set of trials from 1996 to 2004 was obtained from the Capital Resource Center; I examined the entire set of trials the Center had on file during that time period, which was selected because in 1996, life without parole was made an option in capital cases by statute and may have affected the litigation of such cases at trial.

12. Stephen B. Bright, Counsel for the Poor: The Death Sentence Not for the Worst Crime but for the Worst Lawyer, 103 YALE L.J. 1835, 1883 (1994).

13. Id. at $1842-43$.

14. Id. at $1843-50$

15. See, e.g., Williams v. Taylor, 529 U.S. 362, 399 (2000). 
issued in $2008 .^{16}$ These changes have been reflected in Virginia, with certification for capital defense lawyers, more training available, more detailed standards for what is expected of capital defense lawyers, and in 2004, the creation of Regional Capital Defender (RCD) offices.

In this Article, I study what has changed as the death penalty declined in Virginia over the past decade. I wondered whether there were observable differences in the capital trials before and after that decline. I found quite stark differences. Take the case of John "Jose" Rogers, who was charged with capital murder for a rape and murder and was represented by an RCD. The prosecutors did not offer any plea bargain. ${ }^{17}$ The defense lawyers used a new "big firm, New York" approach, or put differently, an "aggressive, thorough, constitutionally adequate litigation approach," investigating their client from the outset. ${ }^{18}$ Before trial and continuing through trial, five lawyers worked on the case with five investigators, two of which were mitigation specialists. ${ }^{19}$ The team consulted with at least six experts, including a jury consultant. ${ }^{20}$ Rogers mounted an alibi defense. There was no eyewitness or other evidence placing him directly at the crime scene, and although some jurors had doubts, the jury found him guilty. There was a four-day sentencing hearing. The team, which spoke to me about the case, presented twenty-one witnesses, compared to just five presented by the State. They focused on humanizing Rogers, the victim of horrifying abuse by his father, who beat and tortured him and made his childhood "a virtual experiment in atrocity, in brutality;" most moving was testimony from his younger brother, who he had tried to shelter from the abuse. $^{21}$ The defense also presented a corrections officer who described him as a model inmate. The jurors were initially deadlocked, with some certain that the death penalty was appropriate, others concerned the evidence was too circumstantial, and others in favor of mercy; Rogers received a life sentence. ${ }^{22}$

16. American Bar Association, Guidelines for the Appointment and Performance of Defense Counsel in Death Penalty Cases (rev. ed. 2003), 31 Hofstra L. Rev. 913 (2003) [hereinafter ABA, Guidelines]; American Bar Association, Supplementary Guidelines for the Mitigation Function of Defense Teams in Death Penalty Cases, 36 Hofstra L. Rev. 677 (2008) [hereinafter ABA, Supplementary Guidelines].

17. E-mail from Joseph T. Flood, Esq. to author (Nov. 2, 2016, 18:21 EST) (on file with author) (describing notes from interview with one of the defense lawyers that represented Rogers).

18. Id.

19. Id.

20. These included a mental health expert, prison risk assessment expert, jury consultant, demographer, pathologist, and a forensic entomologist. Id.; see also Trial Transcript at 171, 186, Commonwealth v. Rogers, CR05000809-02, CR05001101-00, 01, 02, 03 (Va. Cir. Ct. Stafford Cty. Aug. 31, 2006) [hereinafter Rogers Trial Transcript].

21. Id. at 197-99, 219-20, 304.

22. One juror, remarkably, described the deliberations in an online post, noting:

I was on the jury for this trial and there was no doubt that Mr. Rogers committed this crime. There was too much physical evidence against him to prove otherwise. It was unanimous that we all believed beyond a reasonable doubt that he committed this murder. In regards to the sentencing, there was a split 6-6 decision on the death penalty. I was one of the six that chose the death penalty, however we as the jury evenutually [sic] agreed that life in prison would be worse than the death penalty and that there was enough blood shed already. Even though he 
The older set of trials that I studied, dating from 1996 to 2004, look nothing like the Rogers trial. The crucial sentencing phase, at which the judge or jury decided whether to impose the death penalty, was typically cursory, averaging less than two days long.

In the more recent trials, the average was twice that-four days. The defense called the bulk of the witnesses during the sentencing proceedings and cases handled by the Virginia RCD offices were still more complex. The defense's use of experts regarding mitigating evidence such as the defendant's mental health has markedly advanced. The changed understanding of what it takes to effectively litigate whether a person deserves death, together with improved resources for capital defenders in Virginia, may help to explain what has happened over the past decade.

The improvements at trial are representative of the deeper changes in the work that lawyers now do early on in capital defense, producing plea bargains that result in sentences of less than death in the vast majority of cases. There are also other potential explanations for this Virginia decline, including those that would not be reflected in the transcripts of the select cases that go to trial. One could imagine that the introduction of life without parole as an option may have changed incentives for prosecutions and the considerations for jurors. I saw jurors asking about whether parole was a possibility in trials shortly after life without parole was adopted in Virginia in the mid-1990s. ${ }^{23}$ Yet the dramatic decline in death sentences has been far more recent, beginning in 2005.

The exonerations of innocent prisoners may also play a role in attitudes towards the death penalty. There has been only one death row exoneration in Virginia, that of Earl Washington, Jr. in 2001. No changes to rules or practices directly relevant to the death penalty resulted from that case. That said, I was surprised to see how many capital trials continue to involve contested factual questions regarding guilt. Seven of twenty recent capital trials involved innocence defenses. Still other cases raised lack of intent or self-defense. Many cases continue to involve unrecorded confessions to police (seven of twenty cases, few of which were entirely recorded interrogations) or to informants (twelve of twenty cases had informants of one kind or another), or eyewitness identifications (seven of twenty cases). Some cases had quite powerful evidence of guilt, including powerful circumstantial evidence, where the murderer was basically caught in the act, or more probative forms of forensic evidence (thirteen of twenty cases, ten of which involved DNA test results).

did not spare Lisa's life when he had the chance, we spared his. Mercy was granted, but not at a low price. It was the maximum penalty of $100 \mathrm{k}+$ life in jail without the possibility of parole. My heart goes out to both families in this case and it was very difficult to see the hurt on their faces that day. This was an experience that I will never forget myself.

Juror, Man Gets Life for Murder, TopIX: STAFFORD CounTy (Mar. 12, 2013), http://www.topix.com/forum/ county/stafford-va/TPRIEAU6HB400EIOQ [https://perma.cc/TX3F-9QH8]

23. See VA. Code Ann. \$ 53.1-165.1 (West, Westlaw through end of the 2016 Reg. Sess.). 
For the study that I present in Part II of this Article, I obtained a complete collection of transcripts from Virginia cases from 2005 to 2015 at which death was considered by a judge or jury, as well as a large collection of pre-2005 capital trials, discussed by way of comparison in Part III. Detailed descriptions of evidence introduced at trial and sentencing-together with the types of experts testifying, the aggravating and mitigating evidence introduced, whether innocence arguments were raised, and other concrete features of the trials-will hopefully offer a rich picture of what remains of the death penalty in Virginia. Much of what we hear about the death penalty today comes from high-profile cases in which an execution is imminent. Such cases are typically decades old and may not be representative of today's death penalty. In recent Virginia trials, resource centers have changed the litigation of capital cases by presenting far more powerful mitigation defenses than previously seen.

What makes this case study different from the vast body of prior research on death penalty litigation, which has done so much to add to our understanding of the death penalty? Classic large-scale studies conducted over several decades, such as those led by the late Professor David Baldus, focused on all deatheligible homicides in a given state and what factors explain why a few cases resulted in death charges and sentences. Those remarkable studies have sometimes examined the strength of the evidence of guilt or culpability, but they were largely based on news reports (because the bulk of cases resulted in guilty pleas) and aggregate measures of evidence strength (such as using the fact that a case went to trial as an imperfect proxy for strength). ${ }^{24}$ Those studies have found, after painstakingly examining hundreds of factors, that the race of the victim most powerfully explained which cases resulted in death sentences. The Capital Jury Project has for some time done intensive work interviewing jurors from capital trials to assess what factors impacted their decisions. ${ }^{25}$ What this study seeks to add to the large body of knowledge about capital litigation is a detailed case study of trial litigation and evidence. This study is different in that it examines the trial transcripts themselves. Trial records provide a wealth of information about the evidence at the guilt and sentencing phases. Few studies have empirically examined what types of evidence-such as confession evidence or forensics-are presented at death penalty trials or what types of

24. See, e.g., David C. Baldus et al., Equal Justice and the Death Penalty: A Legal and Empirical ANALYSIS 477 n.72, 561, 638-39 (1990) (stating that in 76\% of cases, identification of the defendant is "not in doubt"); Sheri Lynn Johnson et al., The Delaware Death Penalty: An Empirical Study, 97 IowA L. REv. 1925 (2012).

25. See What is the Capital Jury Project?, School of Criminal Justice: University at Albany, http://www.albany.edu/scj/13189.php [https://perma.cc/B74V-HLAM] (descriging the project); see also John H. Blume et al., Lessons From the Capital Jury Project, in Beyond Repair? America's Death Penalty 144 (Stephen P. Garvey ed., 2003) (providing an overview of the Capital Jury Project's findings); William J. Bowers \& Benjamin D. Steiner, Death by Default: An Empirical Demonstrations of False and Forced Choices in Capital Sentencing, 77 TEx. L. Rev. 605 (1999) (describing results of capital juror interviews in which jurors stated misperceptions of what their role was, what the relevant capital sentencing rules were, and described being pressured by fellow jurors into reaching verdicts). 
witnesses are called at the sentencing phase. On the other hand, this effort is necessarily limited by considering only the smaller set of unusual cases that result in a trial. I have supplemented this study with added information about capital charging in the far larger (and increasing) share of cases in which capital murder is charged but where a guilty plea results in a non-death sentence, as well as with interviews with the capital defense lawyers regarding their trial strategy in each of the recent capital trials.

In Part IV, I discuss other possible explanations for these state-level declines, including by turning to data from two other states. Murders have declined in the United States-as has crime generally - which may create a less punitive political climate. Although murders have not declined nearly as rapidly as death sentences have in Virginia, or nationally, the decline in Virginia, as in other states, followed the remarkable drop in murders and violent crime in the 1990 s. $^{26}$ Fewer jurisdictions within Virginia still impose the death penaltyonly seven counties did so in the past decade and most were large counties. In its heyday, a broad range of counties, including quite small ones, imposed large numbers of death sentences. Data from North Carolina, where a similar statewide indigent capital defense system was created, mirrors the story I tell about the declining Virginia death penalty. States that have not made such changes, like Florida, have also experienced a decline in death sentences, but the declines in those states are not nearly as sharp as the decline in states like Virginia and North Carolina.

This study suggests that it does not take a Dream Team to effectively represent a capital defendant. But it does take a team-a team of specialist capital defense lawyers and investigators, preferably working in a single office so that they can work together on multiple cases and not have to begin from scratch in each case. Specialists understand the different way that a death penalty case must be litigated from its inception—-long before trial-and preferably and typically without a trial. These findings have constitutional implications for death penalty cases and beyond. This evidence, as I will describe in the Conclusion: (1) raises heightened Eighth Amendment arbitrariness concerns with the scattered state of the American death penalty; (2) suggests far more attention should be paid to Sixth Amendment ineffective assistance of counsel claims, because death sentencing remains more stable in states that lack consistent trial resources in death penalty cases; and (3) strongly supports the need to establish statewide capital—and non-capital—public defender offices.

Virginia may be a bellwether for the future of the American death penalty. With concerns about wrongful convictions persisting, and the practice of the death penalty increasingly limited to a small number of counties and a small number of cases, the "new" Virginia death penalty raises precisely the heightened Eighth Amendment concerns that motivated Justice Breyer's dissent in

26. See, e.g., VA. Capital Case Clearinghouse: A Legal Clinic at Washington \& Lee Univ. Sch. of LAw, http://www.vc3.org/ [https://perma.cc/SV9T-EA7G] (last visited Oct. 21, 2016). 
Glossip. Although it is still too early to predict an imminent demise of either the American or the Virginian death penalty, what remains of the practice is far more "unusual" than ever before.

\section{The Virginia Death Penalty}

In this Part, I set out the backdrop for the decline of the death penalty in Virginia, which since 1976 was a top death penalty state with a highly expedited process for moving capital cases from a sentence to an execution. Second, I lay out the legal structure of the Virginia death penalty, which permits death sentences for a broad range of murders, and which remains unchanged to this day. Third, I describe how Virginia has seen exonerations in capital cases, calling into question the accuracy of convictions. Fourth, I describe the persistent challenges in providing minimally adequate capital representation in Virginia, culminating in the enactment of legislation establishing RCDs.

\section{A. THE HEYDAY OF THE VIRGINIA DEATH PENALTY}

Virginia has executed, if one includes its colonial history, more individuals than any other state—over 1,300 people. ${ }^{27}$ Virginia has executed 111 people since the death penalty was reinstated post-Furman in 1976, which places it behind only Texas and Oklahoma-although far behind Texas. ${ }^{28}$ Virginia's prominence as a death penalty state was no accident. Virginia lawmakers have adopted a range of procedures designed to expedite capital cases, resulting in comparatively short times from sentence to execution, and a death penalty system seen as extremely prosecutor-friendly. ${ }^{29}$ Those procedures remain firmly in place.

As of this writing, there are six individuals on death row in Virginia, a quite small number compared to a high in the fifties in the 1990s ${ }^{30}$ The figure below was prepared using invaluable data laboriously collected by the Virginia Capital Case Clearinghouse at Washington \& Lee University School of Law, supplemented with data from the Virginia Indigent Defense Commission, appellate rulings and news reports. The number of capital trials has sharply declined in the past ten years. ${ }^{31}$ The proportion of cases involving life sentences (life without parole sentences since 1995) has grown.

27. See Virginia's Execution History, Virginians for Alternatives to the Death Penalty, http://www. vadp.org/dp-info/virginias-execution-history/ [https://perma.cc/R7FS-MBXK] (last visited Oct. 21, 2016) (listing executions).

28. Facts About the Death Penalty, Death Penalty Info. Ctr. (Nov. 7, 2016), hitp://www. deathpenaltyinfo.org/documents/FactSheet.pdf [https://perma.cc/JHA6-VRE8].

29. See infra Section I.B.

30. Those individuals are: William Burns, Anthony Juniper, Ivan Teleguz, Thomas A. Porter, William Morva, and Mark E. Lawlor. See Virginia's Death Row Inmates, Virginlans for Alternatives to the Death Penalty, https://www.vadp.org/dp-info/virginias-death-row-inmates/ [https://perma.cc/ B5DN-MQYE] (last visited Oct. 21, 2016).

31. Va. Capital Case Clearinghouse, supra note 26. These data include only capital trials at which there was a capital sentencing hearing and not trials in which a person was acquitted at the guilt stage or convicted of capital murder but then pleaded guilty to a non-capital sentence. 
Figure 1: Capital Trials in Virginia, 1985-2015.

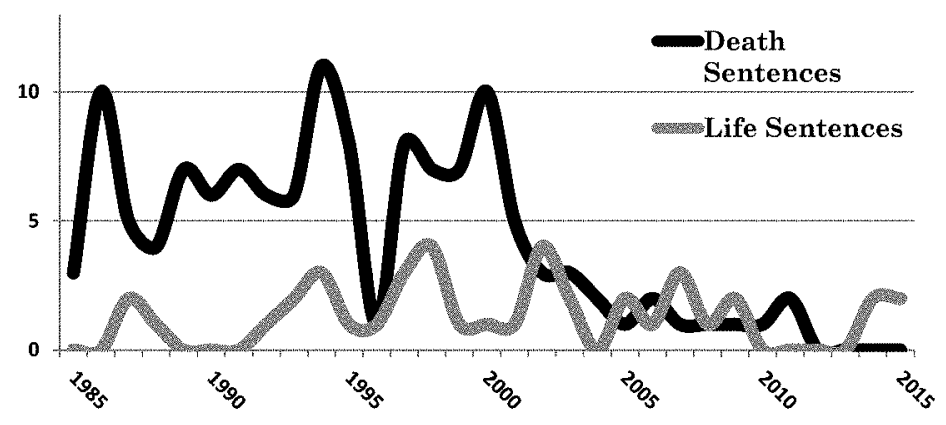

Why is the Virginia death penalty disappearing? There are fewer trials, and far more often than not, prosecutors now fail to get the death penalty when they seek it. To better understand what has happened, I read a collection of these death penalty trials. I obtained a complete collection of transcripts from Virginia cases from 2005 to 2015 during which death was considered by a judge or jury (focusing on trials that occurred after the creation of the RCD offices) as well as a large collection of pre-2005 capital trials (focusing on cases after 1995, when life without parole was first made available as an option in capital cases, to 2004.) ${ }^{32}$ Detailed descriptions of evidence introduced at trial and sentencingtogether with the types of experts testifying, the aggravating and mitigating evidence introduced, whether innocence arguments were raised, and other concrete features of the trials-will hopefully paint a rich picture of what remains of the death penalty in Virginia.

\section{B. THE LEGAL STRUCTURE OF THE VIRGINIA DEATH PENALTY}

The law of the death penalty has not dramatically changed in Virginia-long known as the state that carries out executions the fastest, from judgment to execution. ${ }^{33}$ The law is particularly favorable to prosecutors in Virginia, where the death penalty is broadly available for a wide range of homicides. Capital murder in Virginia includes in its definition fifteen different types of offenses as death eligible, including killing in the commission of abduction; killing more than one person in a single "transaction" or within a three-year period; killing a law enforcement officer, witnesses in a case, or a judicial officer; and killing for hire. $^{34}$

The criteria for imposing the death penalty are also broad in Virginia. Instead of adopting a more detailed set of aggravating and mitigating sentencing factors, as some states have, Virginia has just two aggravating factors: the

32. The Virginia Capital Resource Center was extremely helpful in sharing materials, as were individual lawyers who worked on some of the cases.

33. See infra note 46.

34. VA. Code Anv. $§ 18.2-31$ (West, Westlaw through end of the 2016 Reg. Sess.). 
vileness of the murder and whether the individual poses a threat of future dangerousness. ${ }^{35}$ Both factors are potentially quite broad and vague. Moreover, future dangerousness in Virginia is not carefully informed by empirical research on the actual dangerousness of, say, a prisoner confined to prison for life without parole, but instead refers to a more abstract and generic concept of dangerousness based on prior criminal record or history, or the "circumstances surrounding" the offense.

The non-exclusive list of mitigating factors that may be considered is longer and includes a lack of criminal history, age, and mental impairments. ${ }^{36}$ The vileness and dangerousness factors are not weighed against mitigating factors; the judge or jury must instead consider all of the evidence. ${ }^{37}$ And in Virginia, a judge alone conducts the sentencing following a guilty plea to capital murder. ${ }^{38}$ Victims are entitled to testify at the sentencing hearing. ${ }^{39}$

One quite different type of change made to the death penalty law in Virginia might have been expected to result in fewer death sentences. In 1995, Virginia adopted life without parole by statute, abolishing parole for all Class One felons, including capital murder offenders. ${ }^{40}$ However, it was not until 1999 that the Virginia Supreme Court ruled that jury instructions were required in capital cases, informing the jury of the existence of life without parole as the alternative to a death sentence following a conviction of capital murder. ${ }^{41}$ There was $^{-}$ some change in the number of death sentences in 1995, when life without parole

35. See id. $\$ 19.2-264.4(\mathrm{C})$ (Westlaw) (requiring that death not be imposed unless (1) "there is a probability based upon evidence of the prior history of the defendant or of the circumstances surrounding the commission of the offense of which he is accused that he would commit criminal acts of violence that would constitute a continuing serious threat to society" and (2) the "conduct in committing the offense was outrageously or wantonly vile, horrible or inhuman, in that it involved torture, depravity of mind or aggravated battery to the victim." ).

36. Id. § 19.2-264.4(B) (Westlaw) (listing factors including that "(i) the defendant has no significant history of prior criminal activity, (ii) the capital felony was committed while the defendant was under the influence of extreme mental or emotional disturbance, (iii) the victim was a participant in the defendant's conduct or consented to the act, (iv) at the time of the commission of the capital felony, the capacity of the defendant to appreciate the criminality of his conduct or to conform his conduct to the requirements of law was significantly impaired, (v) the age of the defendant at the time of the commission of the capital offense, or (vi) even if $\$ 19.2-264.3: 1.1$ is inapplicable as a bar to the death penalty, the subaverage intellectual functioning of the defendant.").

37. Id. \& 19.2-264.2 (Westlaw).

38. Id. $\$ 19.2-257$ (Westlaw) ("Upon a plea of guilty in a felony case . . the court shall hear and determine the case without the intervention of a jury."); see also Sarah Breslow, Pleading Guilty to Death: Protecting the Capital Defendant's Sixth Amendment Right to a Jury Sentencing after Entering a Guilty Plea, 98 Cornell L. Rev. 1245 (2013).

39. Id. $\S 19.2-264.4$ (A1) (Westlaw).

40. Id. $\S 53.1-165.1$ (Westlaw).

41. Yarbrough v. Commonwealth, 519 S.E.2d 602, 616 (Va. 1999) ("[I]n the penalty-determination phase of a trial where the defendant has been convicted of capital murder ... the trial court shall instruct the jury that the words 'imprisonment for life' mean 'imprisonment for life without possibility of parole."'); see also VA. CoDE ANN. § 19.2-264.4(A) (West, Westlaw through end of the 2016 Reg. Sess.) ("Upon request of the defendant, a jury shall be instructed that for all Class 1 felony offenses committed after January 1, 1995, a defendant shall not be eligible for parole if sentenced to imprisonment for life."). 
took effect; a string of people convicted of capital murder received life without parole, and death sentences dropped. ${ }^{42}$ One juror, in choosing a life without parole sentence in 1996, commented: "I' $m$ not sure what we would have done if we knew he could get out. I'm glad we had the choice we did." ${ }^{43}$ However, as Figure 1 depicts, death sentences rebounded again in the late 1990s, surpassing earlier levels. ${ }^{44}$

Appellate and post-conviction procedures also impact the disposition of death penalty cases in Virginia. ${ }^{45}$ Virginia death row inmates "spend the shortest time on death row prior to execution-on average, just 7.1 years-compared to a national average of just over 14 years for those executed in 2009."46 The Virginia Supreme Court expedites death penalty appeals, giving them first priority on its docket. ${ }^{47}$

The landmark "Broken System" study by James Liebman, Jeffrey Fagan, and Valerie West found outcomes in Virginia "highly anomalous, given the State's high execution rate (nearly double that of the next nearest state, and 5 times the national average) and its low rate of capital reversals (nearly half that of the next nearest state, and less than one-fourth the national average). ${ }^{98}$ The Fourth Circuit Court of Appeals rarely granted habeas corpus in capital cases and frequently reversed lower courts that did grant relief. ${ }^{49}$

42. Associated Press, Fewer Killers Get Death Penalty Since Virginia Abolished Parole, VIRGINIANPiLot, Nov. 25, 1996, at B7; see supra Figure 1.

43. Peter Finn, Given Choice, Va. Juries Vote for Life, WASH. Post, Feb. 3, 1997, at A01.

44. For an empirical study regarding the question whether adoption of life without parole by death penalty states is associated with declines in death sentencing (and finding weak support for the notion that life without parole has any such impact), see Ankur Desai, Note: The Machine Stops: How Professional Capital Defenders are Ending Use of the Death Penalty in America (draft on file with author).

45. See Barky Latzer \& James N.G. Cauthen, Justice Delayed? Time Consumption in Capital Appeals: A Multistate Study 40 (2006) (finding that "[t]he Virginia Supreme Court works the fastest [to resolve capital cases], producing opinions in little more than three months").

46. STUDIES: Virginia Leads the Country in Death Sentences Resulting in Executions, DEATH Penalty INFo. CTR., http://www.deathpenaltyinfo.org/studies-virginia-leads-country-death-sentencesresulting-executions [https://perma.cc/Q2N3-UTCX] (last visited Oct. 30, 2016); see also Frank Green, Path to Execution Swifter, More Certain in Va., Richmond Times-Dispatch (Dec. 4, 2011, 12:00 AM), http://www.richmond.com/archive/article_6a4bf4fc-bff8-52b5-be5b-7d2598439957.html?mode= print [https://perma.cc/6DER-GP5X].

47. VA. Sur. CT. R. 5:23(b)(1) (giving first docketing preference to capital appeals).

48. James Liebman, Jefrrey Fagan \& Valerie West, A Broken System: Error Rates in Capital CASEs, 1973-1995, at 15 (2000).

49. For a detailed analysis and collection of Fourth Circuit opinions from the time period from 1983 to 2009 , during which one does not see grant or affirmance of relief until 2005 (and out of 277 total dispositions in capital cases, there were only six affirming grant of habeas relief and eight reversing denial of habeas petition), see Keir Weyble, The Fourth Circuit Capital Habeas Cases in the Modern Era (on file with author). To be sure, more recent changes to the composition of the Fourth Circuit Court of Appeals may impact disposition of federal habeas petitions by the remaining death row inmates in Virginia in the future. Brian S. Clarke, The Moderation of the Fourth Circuit, 66 S.C. L. Rev. 927, 927 (2015) ("The Fourth Circuit has changed. What was, a few short years ago the most stridently conservative Court of Appeals in the country, has become-since 2010 - a moderate, if not slightly liberal, court."). 
The American Bar Association recently concluded an in-depth assessment of the procedures surrounding handling of capital cases in Virginia, focusing additionally on procedures surrounding criminal discovery, investigations and evidence gathering, and other features of criminal justice in Virginia that impact capital cases. ${ }^{50}$ Virginia has some of the most restrictive discovery rules in the country, making it quite difficult for defense lawyers facing a "trial by ambush" situation. Despite detailed recommendations from a multiyear task force, the Virginia Supreme Court rejected proposed discovery rule changes. ${ }^{51}$ Thus, capital lawyers still face the same minimal discovery rules they grappled with in the past.

There are currently seven individuals on Virginia's death row. ${ }^{52}$ In the 1990 s, there were as many as thirteen executions in a single year, and as noted, Virginia and Texas lead the country in executions. ${ }^{53}$ Over the past decade, the murder rate in Virginia has dropped as violent crime has declined generally; arrests for murder show a gradual decline (although with upticks in some years, including in 2015) ${ }^{54}$ How many of those murders were capital eligible is unknown and would be difficult to assess given the breadth of some of the criteria.

\section{EXONERATIONS IN VIRGINIA}

Another potential factor affecting the Virginia death penalty is that beginning in the late 1980s, DNA testing has exonerated prisoners in Virginia, including in capital cases. In one case, David Vasquez, an intellectually disabled young man, was charged with capital murder following his confession to the police, during which police spoon-fed him details concerning the crime and recorded themselves doing so. ${ }^{55}$ When the judge ruled his confession would be admissible, he

50. See American Bar Association, Evaluating Fairness and Accuracy in State Death Penalty Systems: The Virginia Death Penalty Assessment Report: An Analysis of Virginia's Death Penalty Laws, Procedures and Practices (2013), http:/www.americanbar.org/content/dam/aba/administrative/ death_penalty_moratorium/va_complete_report.authcheckdam.pdf [https://perma.cc/P5D8-799W] [hereinafter ABA, Evaluating Fairness and Accuracy]. See generally Joint Legislative Audit \& Review Comm'n Of The Va. Gen. Assembly, Review Of Virginia's System Of Capital Punishment (2002), http://jlarc.virginia.gov/pdfs/reports/Rpt274.pdf [https://perma.cc/3RE6-7V96].

51. Frank Green, Justices Reject Recommendations on Pretrial Discovery in Criminal Cases, Richmond Times-DisPaTch (Nov. 26, 2015, 10:30 PM), http://www.richmond.com/news/article_a7518ce 0-3e7c-5696-8cc2-0dda708dd9b1.html?mode=print [https://perma.cc/D4M6-38CL].

52. See Virginia's Death Row Inmates, supra note 30.

53. Frank Green, Virginia Bucks Death Row Flow-Number of Condemned Down, Richmond Times-Dispatch, Mar. 13, 2000, at A-1.

54. See Table 4: Crime in the United States, by Region, Geographic Division, and State, 2014-2015, FBI, UNIF. CRIME RePORTing, https://ucr.fbi.gov/crime-in-the-u.s/2015/crime-in-the-u.s.-2015/tables/table4 [https://perma.cc/NS9A-Z8RY] (last visited Nov. 29, 2016) (noting 350 arrests for murder and non-negligent manslaughter in 2014 and 383 in 2015); Table 5: Index of Crime by State, 2000, FBI, UNIF. CRIME REPORTING, https://ucr.fbi.gov/crime-in-the-u.s/2000 [https://perma.cc/J95Y-KRJE] (last visited Nov. 29, 2016) (noting 401 arrests for murder and non-negligent manslaughter in 2000).

55. Brooke A. Masters, Lucky Release from a Life Behind Bars, WASH. Post (Apr. 28, 2000), https://www.washingtonpost.com/archive/politics/2000/04/28/lucky-release-from-a-life-behind-bars/ 0ea9755b-3c88-4389-b44d-b54f6abd98e3/ [https://perma.cc/6Z24-SZUM]. 
pleaded guilty and avoided the death penalty; later DNA tests pointed to another individual, and he was exonerated in $1989 .{ }^{56}$ In other cases, clemency has been granted due to concerns with innocence. Death row inmate Robin Lovitt was granted clemency in 2005, due to concerns with the destruction of key evidence that could be forensically tested in the case..$^{57}$

The best-known (and also the only) Virginia death row DNA exoneration was that of Earl Washington Jr., an intellectually disabled farmhand, who was in prison for eighteen years - and in fact came within nine days of being executedbefore DNA evidence exonerated him. ${ }^{58}$ The case involved the rape and murder of a woman in the town of Culpeper, Virginia. The central evidence at trial was a confession statement in which he appeared to have volunteered key details about how the murder took place and the shirt he left behind at the scene. ${ }^{59}$ On appeal, the Virginia Supreme Court noted how "the defendant identified the shirt as his own by pointing out a unique characteristic he recognized, a place where a patch had been ripped from a pocket." ${ }^{\circ 0}$ The Fourth Circuit Court of Appeals dismissed his habeas petition, emphasizing "Washington had supplied without prompting details of the crime that were corroborated by evidence taken from the scene and by the observations of those investigating the [victim's] apartment." ${ }^{\circ 1}$

Although DNA tests cleared Washington in 1993, the Governor at the time cited to those details in his confession statement, commuting his sentence only to life. Finally, in 2000, new DNA tests were conducted, confirming his innocence and matching an individual in the federal DNA databank; Washington's pardon was granted. In February 2001, Earl Washington Jr. was finally freed. ${ }^{62}$ Washington's case also helped to encourage enactment of a Virginia statute providing a right to DNA testing and relief based on new evidence of innocence. ${ }^{63}$ No death row exonerations have occurred in Virginia since Washington's, and although his exoneration did lead to that change in the postconviction procedures, it did not contribute to any changes to the procedures or resources available in capital cases.

56. Id.

57. David Stout, Clemency Stops an Execution in Virginia, N.Y.Times (Nov. 30, 2005), http://www. nytimes.com/2005/11/30/us/clemency-stops-an-execution-in-virginia.html [https://perma.cc/ARH2CV2G].

58. I describe the facts of the Washington case in more detail in Chapters 2 and 6 of my book, Brandon L. Garrett, Convicting the Innocent: Where Criminal Prosecutions Go Wrong 29-31, 146-48 (2011). For the entire story of the case, see Margaret Edds, An Expendable Man: The

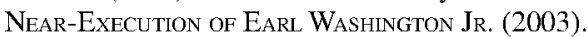

59. GarretT, supra note 58, at 29-31.

60. Washington v. Commonwealth, 323 S.E.2d 577, 587 (Va. 1984).

61. Washington v. Murray, 4 F.3d 1285, 1292 (4th Cir. 1993).

62. James Dao, Lab's Errors in ' 82 Killing Force Review of Virginia DNA Cases, N.Y. TIMEs (May 7 , 2005), http:/query.nytimes.com/gst/fullpage.html?res=9403E4DC1530F934A35756C0A9639C8B63 [https://perma.cc/WJ5G-5GZA].

63. VA. Code Ann. $\$ 19.2-327.1$ (West, Westlaw through end of the 2016 Reg. Sess.). 


\section{CAPITAL REPRESENTATION}

Concerns with the quality of representation in death penalty cases are longstanding, particularly in Virginia. ${ }^{64}$ Lawyers were traditionally paid little to represent indigent defendants in death penalty cases in Virginia. For some time, the maximum fee was capped at $\$ 650 .{ }^{65}$ By 2000 , the average fee was $\$ 29,800 .{ }^{66}$ Today, death penalty lawyers appointed by the court are paid an amount deemed "reasonably necessary" by the judge and approved by the chief judge of the court, with hourly rates of no more than $\$ 200$ per hour in-court and $\$ 150$ per hour out-of-court. ${ }^{67}$ The change is certainly an improvement over the abysmal rates in the past, but the rates are still quite low. ${ }^{68}$ Virginia long did not provide counsel during capital post-conviction proceedings. This was the subject of a Supreme Court ruling finding no constitutional right to counsel post-conviction, but with a concurring opinion that has encouraged provision of such counsel. ${ }^{69}$ Since 1992, the Virginia Capital Representation Resource Center has represented death row inmates post-conviction. Virginia death sentences continue to be reversed on grounds of ineffective assistance of counsel; the case of William Morrisette is one example. ${ }^{70}$ Under the Supreme Court's test in Strickland v. Washington, an inmate must show that their trial lawyer's performance was extremely deficient and unreasonable, and that this subpar performance materially "prejudiced" the case, meaning that there is a reasonable probability that the result would have otherwise been different. ${ }^{71}$

Prior to Williams v. Taylor, the U.S. Supreme Court had never found defense counsel ineffective in a capital case, but beginning with that case in 2000 , and then in subsequent cases-Wiggins v. Smith, ${ }^{72}$ Rompilla v. Beard, ${ }^{73}$ Porter v. McCollum, ${ }^{74}$

64. See Bright, supra note 12.

65. aClu of Va., Unequal, Unfair and Irreversible: The Death Penalty In Virginia 14 (2000).

66. $I d$.

67. VA. Code Ann. \$ 19.2-163(2) (West, Westlaw through end of the 2016 Reg. Sess.); see also Supreme Court of VA., Chart of Allowances 7, 14-15 (2014), http://www.courts.state.va.us/courtadmin/ aoc/fiscal/chart2014_0701.pdf [https://perma.cc/KBB9-VMPH].

68. See generally Va. State Crime Comm'n, Capital Representation Of Indigent Defendants: To THE GOVERnOR AND tHE General AsSembly of VirGinia (1999), http://leg2.state.va.us/dls/h\&sdocs.nsf/ fc86c2b17a1cf388852570f9006f1299/939776fb00eb48198525676000606490/SFILE/HD60_1999.pdf [https://perma.cc/8V4Y-Q999].

69. See ACLU OF VA., supra note 65, at 28.

70. Morrisette v. Warden of Sussex I State Prison, 613 S.E.2d 551, 563 (Va. 2005).

71. 466 U.S. 668,687 (1984).

72. 539 U.S. 510, 524 (2003) ("Despite these well-defined [ABA] norms, however, counsel abandoned their investigation of petitioner's background after having acquired only rudimentary knowledge of his history from a narrow set of sources.").

73. 545 U.S. 374, 383 (2005) (finding counsel "deficient in failing to examine the court file on Rompilla's prior conviction.").

74. 558 U.S. 30, 40 (2009) (per curiam) (finding that counsel "failed to uncover and present any evidence of Porter's mental health or mental impairment, his family background, or his military service. The decision not to investigate did not reflect reasonable professional judgment ... Porter may have been fatalistic or uncooperative, but that does not obviate the need for defense counsel to conduct some sort of mitigation investigation.”). 
and Sears v. Upton ${ }^{75}$ - the Court found counsel ineffective for failing to properly investigate mitigation evidence at the penalty phase of capital trials. As I will describe in this Article, the performance by counsel in Williams v. Taylor, a Virginia case, was not atypical at the time. ${ }^{76}$ Terry Williams' lawyers "did not begin to prepare for [the sentencing] phase of the proceeding until a week before the trial." $" 77$ And "they failed to conduct an investigation that would have uncovered extensive records graphically describing Williams' nightmarish childhood;" they similarly failed to introduce evidence that he was "borderline mentally retarded," did not advance beyond sixth grade, or that he received commendations for his behavior in prison. ${ }^{78}$

Since that time, capital defense standards changed nationwide, as a result of ABA standards first issued in 1989 and revised in 2003 to emphasize the importance of carefully preparing a mitigation case. ${ }^{79}$ Those Guidelines emphasize that "immediately upon counsel's entry into the case," a mitigation investigation should begin, exploring family history; records from courts, schools, social services, and other government agencies; consulting experts concerning the competency to stand trial, insanity, intellectual disability, cultural background; and making possible overtures to the victim's family, clergy, and others. ${ }^{80}$ The standards emphasize comprehensive litigation of a mitigation case, combined with an early and thorough investigation of the evidence of guilt and a continuing duty to investigate at all phases of the case. The Guidelines emphasize a team approach. The defense team should include "at least one mitigation specialist and one fact investigator" and at least one member "qualified by training and experience to screen individuals for the presence of mental or psychological disorders or impairments." ${ }^{81}$ Supplemental Guidelines issued in 2008 focus on the role of counsel in developing mitigation evidence in capital cases. ${ }^{82}$

The number of capital sentences in Virginia began to steadily drop in 2004, and one question is whether a nationwide recognition that greater capital defense resources were needed began to be reflected in Virginia practice. ${ }^{83} \mathrm{In}$ 2003 , there were six death sentences, and that was the last year in which there were more than two death sentences in Virginia. ${ }^{84}$ In most recent years there have been none. ${ }^{85}$ The most recent capital trial, which occurred as this Article

75. 561 U.S. 945, 955 (2010) (per curiam) (finding a "facially deficient mitigation investigation").

76. 529 U.S. 362 (2000).

77. Id. at 395.

78. Id. at 395-96.

79. See ABA, Guidelines, supra note 16; Eric M. Freedman, Re-stating the Standard of Practice for Death Penalty Counsel: The Supplementary Guidelines for the Mitigation Function of Defense Teams in Death Penalty Cases, 36 Hofstra L. Rev. 663, 664 (2008).

80. See ABA, Guidelines, supra note 16, at 10.7.

81. Id. at $10.4(\mathrm{C})(2)(\mathrm{a}),(\mathrm{b})$.

82. See ABA, Supplementary Guidelines, supra note 16.

83. See supra Figure 1.

84. $I d$.

85. Id. 
was being revised for publication in August 2016, resulted in a life sentence. ${ }^{86}$ What changed in Virginia in the early 2000s? There was only one change in the law, and it occurred precisely at that time. In 2002, the General Assembly authorized the creation of four RCD offices, which were then established in 2002 and $2003 .^{87}$

Why take that step? In part, centering capital defense in offices would save money. However, lawmakers were also concerned about reports regarding uneven quality of defense, which lacked the ability to do the work described in the ABA standards. Perhaps the Williams v. Taylor decision played some role, as well as the 2003 revisions to the ABA standards. At the time, the Virginia Crime Commission found that public defenders tended to obtain shorter sentences for their clients than court-appointed lawyers. The Crime Commission said, "There's some cost savings, but really it's an expertise issue. It's such a complex area."88 In 2004, Virginia passed legislation requiring the adoption of indigent defense standards for capital defense lawyers, including certification by the Indigent Defense Commission. These standards were in place when the RCD offices began accepting cases in $2004 .^{89}$ Legislators were reacting to a report prepared for the ABA, which after nine months of intensive study called the system of indigent defense "deeply flawed" with "substandard practice" the "norm," and with pay for court-appointed lawyers in Virginia "the lowest in the nation."90

The four RCD offices have attorneys working on death penalty cases full time and staff specially qualified to represent capital defendants at trial. The offices have resources to investigate death penalty cases, including with a focus on mitigation evidence. Prior to the creation of these offices, locally appointed lawyers and public defenders represented indigent capital defendants on trial and appeal (and an Appellate Defender took those cases for five years but then closed for lack of funding). ${ }^{91}$ At least one lawyer from an RCD is supposed to

86. Alix Bryan \& Jake Burns, Life Sentence for Man Who Murdered Virginia State Trooper, WTVR (Aug. 3, 2016, 5:49 PM), http://wtvr.com/2016/08/03/russell-brown-life-sentence/ [https://perma.cc/ GUF4-N2CU].

87. Va. Code Ann. $§ 19.2-163.2$ (West, Westlaw through end of 2016 Reg. Sess.); see also ABA, Evaluating Fairness and ACCuRacy, supra note 50, at 143-44; John D. Tuerck, Tidewater to have Second Capital Office, VA. Laws. WkLY., Aug. 12, 2002, at 1, 20.

88. Editorial, State Funds Public Capital Defense for Indigent, DalLY Press (Newport News, VA), Dec. 9, 2002, at A12.

89. VA. Code Ann. § 19.2-163.8(A) (West, Westlaw through end of 2016 Reg. Sess.). Other states with similar legislation include: N.C. GEN. STAT. ANN. \$ 7A-498.2 (West, Westlaw through Chapters 93, 95 to 99 and 101 of the 2016 Reg. Sess.) (establishing Office of Indigent Defense Services); GA. CoDE AnN. § 17-12-121 (West, Westlaw through 2016 Reg. Sess.) (creating the Office of the Georgia Capital Defender).

90. Editorial, Justice Denied in Virginia, Wash. Post, Feb. 10, 2004, A22; The Spangenberg Grp., A Comprehensive Review of Indigent Defense in Virginia 2 (2004), http://www.americanbar.org/content/ $\mathrm{dam} / \mathrm{aba} / \mathrm{migrated} /$ legalservices/downloads/sclaid/indigentdefense/va_report2004.authcheckdam.pdf [https://perma.cc/3TRY-NE6M].

91. ABA, Evaluating Fairness and ACCuracy, supra note 50, at 144; Jeremy P. White, Establishing a Capital Defense Unit in Virginia: A Proposal to Increase the Quality of Representation for Indigent Capital Defendants, 13 CAP. DeF. J. 323, 349-50 (2001). 
be appointed when the death penalty is charged (unless the RCD is conflicted from taking the case), but depending on when a capital charge is made, this may occur some time after arrest, and in the meantime, a lawyer may be appointed with little familiarity with capital litigation and without resources to conduct investigation, review mitigation evidence, or obtain experts. ${ }^{92}$ Virginia also expanded access to expert evidence in death penalty cases in 2005 , including requests for testing from the state crime lab, and in 2010, a statute provided that requests for qualified experts can be made ex parte. ${ }^{93}$ By all accounts, this team approach has "significantly improved the quality of representation available to Virginia's indigent defendants in death penalty cases." 94

In September 2015, newly enhanced capital representation standards came into effect in Virginia, following a comprehensive review by a joint study committee including the Supreme Court of Virginia, the Indigent Defense Commission, and the Virginia State Bar. ${ }^{95}$ The new rules tighten the qualifications for capital counsel, including by requiring all capital counsel to keep their training current, rather than crediting experience or initial training as was permitted in years past. ${ }^{96}$ These changes should further improve capital defense lawyering in Virginia.

\section{Findings: Virginia Capital Trials from 2005-2015}

When examining Virginia capital trials litigated since 2005, as well as cases in the decade prior, I was interested in analyzing both the guilt and the sentencing phases. The sections that follow examine the charging phase before trial and then the guilt and sentencing phases at trial. As to the guilt phase, I was particularly interested in studying the types of evidence supporting guilt. I wondered how many cases involved contested questions concerning guilt, and I was surprised to see that even in an era where far fewer death penalty cases are brought to trial, prosecutors still bring cases in which guilt is contested. I wondered whether more modern forms of evidence like DNA testing had changed death penalty practice, and to some degree they have. With highly restrictive discovery rules in Virginia, the guilt phase evidence may be quite difficult for counsel to contest. Second, I was particularly interested in the sentencing phase, where it is the defense that has unusual opportunities to present evidence about their client-evidence in their control, but evidence that may be complex and require expert assistance. At the sentencing phase in particular, given the creation of the RCDs in 2004, I wondered whether differences in lawyering could be observed, including whether the RCD lawyers or

\footnotetext{
92. See $\mathrm{V}_{\mathrm{A}}$. Code AnN. § 19.2-163.7 (West, Westlaw through end of the 2016 Reg. Sess.).

93. Id. at $\S 9.1-1104, \S 19.2-264.3: 1.3(\mathrm{~A})$ (Westlaw).

94. ABA, Evaluating Fairness And ACCURACy, supra note 50, at iv.

95. See Capital Counsel Qualifications Standards Review Committee Report (2014), http://www. publicdefender.state.va.us/PDF\%20documents/Final\%20Recommendations\%20Report.pdf [https://perma. cc/67G8-S9BG]

96. Id. at 1 (noting prior rules were "primarily experience-based").
} 
other experienced defense lawyers have adopted new strategies in capital litigation. The sections below describe the findings of this study of Virginia capital trials, and in the next Part I will then ask whether this approach can shed light on the current state of the death penalty in other states.

\section{A. CAPITAL CHARGING}

There have been no death sentences handed down in Virginia since 2011. From 2004 to 2011, there were no more than two death sentences per year. The figure below depicts the same data I collected that was displaed in Figure 1, but focusing just on capital trials in the seventeen years from 1998-2015, during the time period surrounding the decline in death sentences.

Figure 2: Capital Trials in Virginia, 1998-2015.

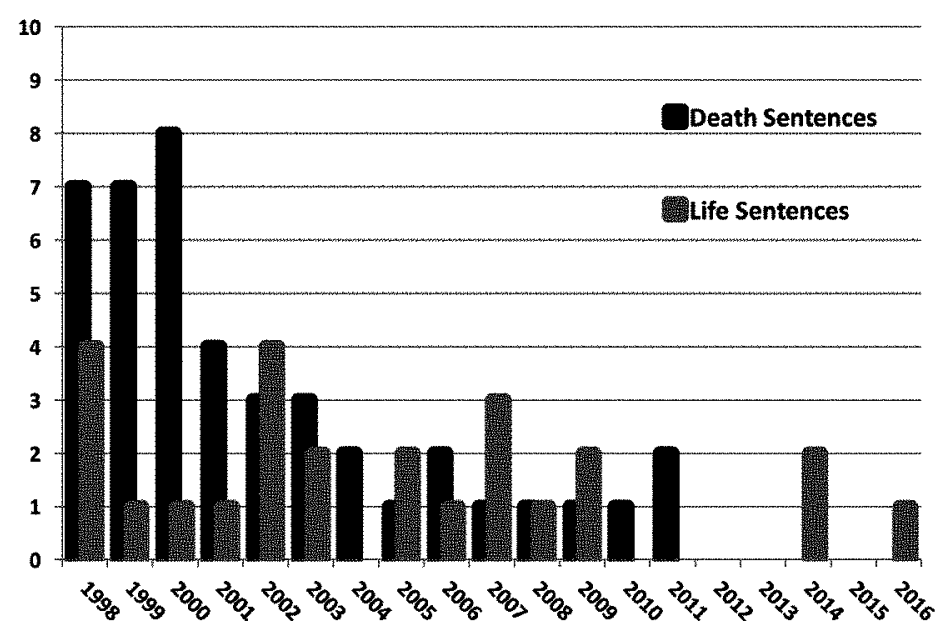

Each year, prosecutors file far more capital murder charges than there are capital trials. The capital cases that go to trial represent just the tip of an iceberg. The average, from 2008 to 2013 was twenty-two cases with capital murder charges per year. Although the death penalty has declined in Virginia, there has been no appreciable drop in capital murder charges. ${ }^{97}$ As Professor John Douglass has explored, "capital charging in Virginia persists at a relatively

97. According to the Indigent Defense Commission, there were twenty-two capital cases in 2008, twenty-six in 2009, fifteen in 2010, twenty-three in 2011, twenty-two in 2012, and twenty-three in 2013. Virginia Indigent Defense Commission, Review of the Capital Defender Offices Appendix B (Dec. 12, 2013). According to the Virginia Supreme Court's Circuit Court Case Management System, there were seven life sentences in 2008 for completed capital murder convictions, nine in 2009, nine in 2010, and seven in 2011. Id. at Appendix A. These data were supplemented with 2014 and 2015 data from the Virginia Supreme Court, collecting cases coded as capital for which vouchers were paid by that Court's criminal fund. I thank David Bruck for sharing those data. Virginia Indigent Defense Comm'n, Capital Murder Defendants, FY 2004 to Date (on file with author) [hereinafter Capital 
stable rate," where "Virginia's death penalty functions primarily as a bargaining chip in a plea negotiation process that resolves most capital litigation with sentences less than death." ${ }^{.98}$ Figure 3 illustrates these data.

Figure 3: Capital Charging and Trials in Virginia, 2008-2014.

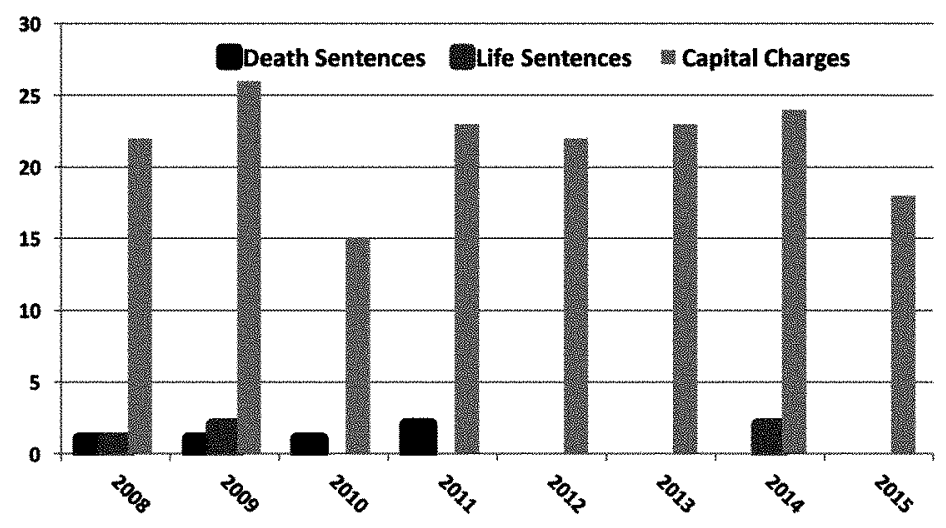

The vast majority of the cases in which capital murder is charged do not result in capital murder convictions. Instead, they result in life sentences or sentences of less than life, with some outright acquittals. As Professor Douglass describes, this represents a real change from the data presented in a 1990s study of capital charging in Virginia, in which twice as many cases went to a capital trial. ${ }^{99}$ The work that lawyers do matters far more during the early stages of an investigation and then plea negotiations, than it does in the unusual cases that now proceed to trial. Indeed, many of these cases that now do not result in death sentences look much like the types of cases that in previous years might have resulted in the death penalty. For example, a man facing capital murder charges in the shooting deaths of his wife, her daughter, and his uncle, repeatedly punched his attorney in the face in open court during his competency hearing; he was later found not guilty by reason of insanity and, as a result of a plea, was committed to a mental hospital for life. ${ }^{100}$ In another recent case, a defendant

Murder Defendants, FY 2004 to Date]; Virginia Indigent Defense Comm'n, Capital Murder DefenDANTS, FY 2012 To DATE (on file with author).

98. John G. Douglass, Death as a Bargaining Chip: Plea Bargaining and the Future of Virginia's Death Penalty, 49 U. Rich. L. Rev. 873, 873-74 (2015).

99. For an insightful and detailed discussion of the studies of capital charging in Virginia, see $i d$. at $881-87$.

100. Daily Mail Reporter, Horror in Court as Man Accused of Three Murders Attacks Attorney and Repeatedly Punches Him in the Face, DALY MAL (Aug. 2, 2012, 1:09 PM), http://www.dailymail.co.uk/ news/article-2182789/Horror-court-man-accused-murders-attacks-attorney-repeatedly-punching-face. html [https://perma.cc/5RZV-M3AB]; Colleen Quigley, Judge Accepts Insanity Plea in Madison Co. Triple Slaying, NEwSPLEx (Sept. 5, 2014, 1:49 PM), http://www.newsplex.com/home/headlines/JudgeAccepts-Insanity-Plea-in-Madison-Co-Triple-Slaying-273982811.html [https://perma.cc/7QL6-8PK3]. 
was convicted of first-degree murder but acquitted of capital murder, apparently due to concerns with the credibility of a co-defendant who received a deal in exchange for his testimony. ${ }^{101}$ Higher quality lawyering may play an important role in those outcomes. ${ }^{102}$

In another recent case in Virginia Beach, the defendant entered an Alford plea to reduced charges after lawyers listened to tapes of phone calls made from jail. Jailhouse informants were making detailed (and recorded) plans with relatives to obtain public information about the murder so that they could fabricate evidence against the defendant; they talked about how "the cooperation thing" is "the key to ... freedom," and how prosecutors and police "just want convictions . . .."103 Had the lawyers at an RCD not spent countless hours poring over those phone records undermining the credibility of the jailhouse informant evidence, and had they not received discovery of these informants' involvement, the case might have gone to trial and resulted in a conviction. The resources and strategies used by RCD lawyers in Virginia may be far more important in the cases that never result in a trial.

Another important qualification concerning the limitations of the data studied here is that the trial transcripts obtained included the guilt and sentencing phases of trial, but not the process of jury selection. Where "[t]he conventional wisdom is that most trials are won or lost in jury selection," jury selection is crucial in capital trials and can be highly complex. ${ }^{104}$ Measuring and assessing counsel's performance during that phase would have been highly instructive. ${ }^{105}$ Today, defense counsel are better trained on how to use more sophisticated methods to ensure, for example, that jurors who would automatically sentence a defendant to death no matter what the evidence are not empanelled. ${ }^{106}$ Whether judges in Virginia permit full use of prior capital jury selection methods is equivocal, but was not studied here.

In focusing on the guilt and sentencing phases of trial, and attempting to assess counsel's work at trial, I found that just under half of the death penalty

101. Laurence Hammack, 23-Year-Old Faces Potential Life Sentence in Alleghany County Killing, RoAnoke Times (Oct. 21, 2015, 3:00 PM), http://www.roanoke.com/news/crime/year-old-faces-potentiallife-sentence-in-alleghany-county-killing/article_19bb3958-fc1f-5008-83ec-e40a7a4b1af3.html [https:// perma.cc/7K4A-NC7S].

102. One can compare these outcomes to the case of Robert Gleason, discussed infra Part II.C.1, in which the defendant represented himself pro se, presented no mitigation, and was executed, and the Edward Bell case, discussed in Part III, which involved informant evidence.

103. Elisabeth Hulette, Are Jailhouse Informants Lowering the Bars?, VIRGLNIAN-P $\amalg$ (June 8, 2014), http://pilotonline.com/news/local/crime/are-jailhouse-informants-lowering-the-bars/article_f 9993 a46-7a0d-55ca-83e7-9dc0b5e33f8d.html [https://perma.cc/WW3N-2748].

104. John H. Blume, Sheri Lynn Johnson, \& A. Brian Threlkeld, Probing "Life Qualification" Through Expanded Voire Dire, 29 Hofstra L. Rev. 1209, 1209 (2001).

105. A Capital Jury Project study of Virginia capital jurors found in a small sample of responses at least one individual who should have been excluded. Stephen P. Garvey \& Paul Marcus, Virginia's Capital Jurors, 44 WM. \& MARY L. Rev. 2063, 2072-75 (2003).

106. See, e.g., Matthew Rubenstein, Overview of the Colorado Method of Capital Voire Dire, Champion, Nov. 2010, at 18. 
trials from 2005 to present involved lawyers from an RCD (ten of twenty-one trials). Of the eleven capital sentencing trials since 2005 where life was imposed, six involved RCDs (six of the ten cases in which an RCD was appointed). Sentencing hearings in cases involving RCDs were longer than in cases with appointed lawyers. RCDs also called more defense witnesses on average (averaging nineteen witnesses called for the defense, compared with eleven in non-RCD cases). Those are only rough measures of attorney effort, but they suggest at least that RCDs mount a more complex defense.

\section{B. GUILT PHASE EVIDENCE IN VIRGINIA}

Of the six individuals currently on death row in Virginia, one of the cases involved DNA evidence linking the person to the murders. ${ }^{107}$ Two of the six cases involved confessions. Three involved informant testimony, and two involved persons caught shortly after the crime with the murder weapon. Of those six cases, some involved contested guilt. Most of the other cases instead involved contested issues surrounding mental illness and intellectual disability.

The figure below illustrates, for the capital trials from 2005-2015 detailed in the Appendix, what types of evidence the prosecutors introduced at trial. The Sections that follow will describe this evidence in greater detail.

\section{Figure 4: Prosecution Evidence in Capital Trials in Virginia, 2005-2015.}

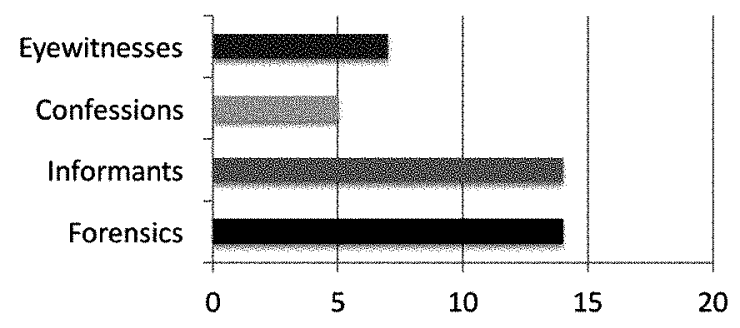

Those capital cases that go to trial in Virginia may be fairly idiosyncratic cases in which prosecutors did not offer a plea or the defense would not accept one. After all, the vast majority of capital murder cases settle. There have been twenty-one capital sentencing hearings from 2005 to present in Virginia. In the case of Alfredo Prieto, executed in October 2015, there were two separate sentencing trials at which the death penalty was available (and imposed) due to

107. Those individuals are: William Burns (confession), Anthony Juniper (jailhouse informant, eyewitness, forensics), Ivan Teleguz (co-defendant/informant testimony), Thomas A. Porter (eyewitnesses, confession, informant testimony, found with murder weapon), William Morva (eyewitnesses, found with victim's weapon), and Mark E. Lawlor (DNA). Virginia's Death Row Inmates, supra note 30; see Tom Jackman, Falls Church Man Mark Lawlor Convicted of Capital Murder, WASH. Post (Feb. 22, 2011, 11:14 PM), http://www.washingtonpost.com/wp-dyn/content/article/2011/02/22/AR20110222 07235.html [https://perma.cc/6D7E-GS82]. 
an appellate reversal, so the case is included twice in the group of twenty-one cases. ${ }^{108}$

Many of the twenty convicts were not mass murderers. Nine of the twenty cases involved one victim. Seven others involved two victims. Two cases involved three victims, and three involved four. As a result, many of the cases were eligible for capital murder not because of number of victims, but for other reasons, such as murder of a law enforcement officer (in three cases) or murder as part of a rape (four cases) or robbery (five cases). This is surprising in that one might expect that in an era of fewer death sentences, the death sentences that are obtained would be in particularly aggravated cases. The Ivan Teleguz case was the only post-2005 case that involved a conviction for murder-for-hire. He was convicted in the stabbing of the mother of his child, allegedly making a payment to the killer of $\$ 2,500$. The conviction was based on the testimony of the actual murderer who stabbed the victim, who received a plea agreement in exchange for his cooperation, and two others, his roommate and accomplice (who have since recanted in post-conviction affidavits). ${ }^{109}$ The case was apparently one that trial counsel could have pled out; life without parole was offered. More aggressive representation, perhaps, could have averted the death sentence. ${ }^{110}$

In addition, five of the twenty-one cases since 2005 have involved guilty pleas to capital murder and therefore little or no development of the evidence at the guilt phase. ${ }^{111}$ When a defendant pleads guilty to capital murder in Virginia, it is the judge and not a jury that adjudicates capital sentencing. Otherwise, the jury decides the question of guilt and whether to impose a death sentence. The judge then orders probation to conduct an investigation of the defendant, reviews the post-sentence report, and rules on the appropriateness of the jury's sentencing decision. ${ }^{112}$ For that reason, five of the twenty-one recent cases involved bench trials only at sentencing, while fourteen of the twenty-one recent cases involved jury trials at the guilt and sentencing phases. The next

108. On Prieto's defense, see, for example, Tom Jackman, Prieto Sentenced to Death for Fairfax Murders, WASH. Post (Nov. 5, 2010, 10:56 PM), http://www.washingtonpost.com/wp-dyn/content/article/ 2010/11/05/AR2010110505550.html [https://perma.cc/CRP4-Z9ZM] [hereinafter Jackman, Prieto Sentenced to Death]. On Prieto's execution, see Tom Jackman, Triple Murderer Alfredo Prieto is Executed in Virginia, WASH. PosT (Oct. 1, 2015), https://www.washingtonpost.com/local/public-safety/judge-allowsexecution-of-alfredo-prieto-to-proceed/2015/10/01/eaec9f28-67c6-11e5-9223-70cb36460919_story. html [https://perma.cc/37CV-A435] [hereinafter Jackman, Triple Murderer].

109. Teleguz v. Pearson, 689 F.3d 322, 325-27 (4th Cir. 2012); Teleguz v. Commonwealth, 643 S.E.2d 708, 728 (Va. 2007).

110. Teleguz also brought a series of ineffective assistance of counsel claims ranging from failures to investigate alibi evidence and impeachment evidence to evidence undercutting aggravating factors that supported the death sentence. Teleguz v. Warden, 688 S.E.2d 865, 869-72 (Va. 2010).

111. Guilt may also be conceded where there is not a plea. See Florida v. Nixon, 543 U.S. 175, 178-79 (2004) (finding no ineffective assistance of counsel where the defense lawyer adopted strategy of conceding guilt).

112. VA. Code Anv. $\$ 19.2-264.4,5$ (West, Westlaw through end of the 2016 Reg. Sess.). 
sections turn from the prosecution case to the defenses presented in response to the evidence of guilt at trial.

\section{Innocence Defenses}

Many of the recent capital trials in Virginia involved defendants asserting the "wrong man" innocence defense. In seven of the twenty cases, defendants asserted innocence defenses, relying on an alibi or an argument concerning the guilt of a third party. For example, John Ragin alleged innocence outright. Prosecutors argued DNA from his murdered wife's fingernails linked him, as did cellphone records, and that he had taken his surviving son and driven to South Carolina following the murder. ${ }^{113}$ In his testimony, Ragin said: "I can't be in South Carolina and Newport News at the same time," adding "It's impossible for my phone records to be in Newport News if I'm in South Carolina. That's self-evident." ${ }^{114}$ That defense, perhaps due to the DNA and cellphone evidence, was not successful, illustrating how much more the defense can often accomplish at the sentencing phase than at the guilt phase, where much of the evidence is presented by the State.

Teleguz's lawyer argued in the opening statement: "The Commonwealth has cut a deal with the killer ... there's no disputing that fact," adding that "[t]here will be no forensic evidence tying Ivan Teleguz to this case." ${ }^{115}$ However, when the judge sentenced Teleguz to death, he explained:

I have heard the entire trial. I have a broad discretion to set aside, or not to set aside but not to impose the death penalty. If I had one iota of doubt as to your guilt I would do so. If I had one iota of doubt as to your viciousness I would do so. ${ }^{116}$

Antwon Whitten testified at his sentencing that "I am the person they put here," and "even though I know the jury done found me guilty," "where is my fingerprints;" "It was a male's DNA but it wasn't mine." 117 "Innocent people walk and people still say, oh, I think he did it, you know."118 He added, "They think I actually did it but, you know, I'm hoping one day to prove that I didn't . . .."119

113. Ashley K. Speed \& Peter Dujardin, Newport News Trial Recap: Prosecutors Make Their Case Against John Ragin, DALY PREss (Mar. 23, 2014), http://articles.dailypress.com/2014-03-23/news/dp-nwsragin-recap-20140323_1_crystal-ragin-john-moses-ragin-la-kwan [https://perma.cc/H2RS-FALH].

114. Ashley K. Speed \& Peter Dujardin, Newport News Death Penalty Case Bucks Trend of Fewer Capital Prosecutions, DALY Press (Mar. 2, 2014), https://law.wm.edu/faculty/inthenews/pdfdocuments/ Gershowitz03042014.pdf [https://perma.cc/WU3L-ZHVV].

115. Trial Transcript at 39, 43, Commonwealth v. Teleguz, No. 30946 (Va. Cir. Ct. Rockingham Cty., Feb. 7, 2006) [hereinafter Teleguz Trial Transcript]

116. Id. at 211 (July 18,2006 ).

117. Sentencing Hearing Transcript at 24, 30, 32, 40, Commonwealth v. Whitten, CR 03001070-00 (Va. Cir. Ct. Stafford Cty. Sept. 2, 2005).

118. Id. at 37

119. Id. at 38 . 
Despite the shrinking number of capital trials in Virginia, a third of the cases feature disputes regarding guilt. Of course, doubts about guilt phase evidence may affect which cases are brought to a trial, just as doubts about whether a person is likely to be sentenced to death may affect whether a case is plea bargained. Doubts about guilt have also been prominent, as noted, in cases in which post-conviction relief and clemency have been granted.

\section{Self-Defense and Additional Defenses}

In additional cases, capital defendants raised claims of self-defense. Some claims of self-defense are particularly hard to assess where there are not clear accounts of what transpired. In two cases, the cases of Jason James and Thomas Porter, there was a particularly detailed self-defense case. In the Jason James case, the defense presented no affirmative evidence (in part because the judge did not permit introduction of certain portions of the defendant's statement to police), but did present a motion to strike, contending that there was no evidence of his prior intent to kill the victims and that the conduct was "without any premeditation"- part only of an altercation that resulted upon his breaking into the house. ${ }^{120}$ The prosecutors responded that, whatever his intent upon entering the house, when confronted by family members, his plan was clear: "they weren't going to call the police and he was not going to jail." 121 The prosecutors pointed to the autopsy and medical evidence concerning stab wounds in "vital portions of the body" that were not due to "flailing around" in self-defense. ${ }^{122}$ The defense responded, "We have four people literally battling for their lives there and from different perspectives. You're not premeditating, you're not meditating on anything, Judge, at that point." ${ }^{123}$ During closing arguments, the prosecutor emphasized that the defendant "entered this house for the evilest of purposes and that was to rape his own cousin," and worse, although these were good people whom he knew, he brought a knife because "he planned what he was going to do."124

Because it was a bench trial, we know how the judge reasoned and decided on the self-defense issue. The judge concluded that the defendant had "numerous opportunities to leave the house," but "chose not to do that. He remained and he came back to continue attacking." 125 The Judge concluded, "I think he had a chance to think about it, not any long plan," but "from these stab wounds, the numbers, the depth of them and what have you, it is clear he intended to do whatever it took not to get caught even if it meant killing them."126 Following a

120. Trial Transcript at 261, 281, Commonwealth v. James, CR06-3045-00F (Va. Cir. Ct. Cty. Henrico, Jan. 23, 2007) [hereinafter James Trial Transcript].

121. Id. at 269.

122. Id. at 268 .

123. $I d$. at 274 .

124. Id. at 301-02.

125. Id. at 323.

126. James Trial Transcript, supra note 120 , at 324 . 
one-day hearing, the judge sentenced James to life in prison. ${ }^{127}$

Still other cases raised additional questions concerning intent to commit murder. An intoxication defense was raised in the Mark Lawlor case, supported by testimony by a psycho-pharmacologist expert. An insanity defense was raised in the Berman Justus case, also supported by expert evidence. As I will develop further, expert development has improved in capital trials in Virginia, even more notably at the sentencing phase than at the guilt phase.

\section{Forensics}

Fourteen of the twenty cases involved a variety of forensics, from ballistics to cell phone records to serology, but in particular, eleven of the cases involved DNA testing. The DNA may not assist with the question of culpability, even if quite probative as to identity; in the James case, the DNA, for example, confirmed that he was the one wearing the mask, but there was no dispute that he was the person who killed the victims. ${ }^{128}$ In William Morva's case, the murdered officer's pistol was found with Morva's DNA on it. ${ }^{129}$ In contrast, in the Alfredo R. Prieto case, it was only due to a "cold hit" in a DNA databank that he was linked to two murders in Virginia. ${ }^{130}$ There was forensic evidence in most of these capital trials that had a guilt phase (fourteen of sixteen). Where there were no forensics, defense lawyers emphasized as much, as in the Teleguz trial. Similarly, in William Shanklin's case, the defense lawyer pushed that issue: "No DNA. Where is the DNA?"131 The question of discovery concerning forensics also remains a live issue in Virginia; in the Lawlor case, DNA tests implicated Lawlor, but the trial judge denied requests to conduct mitochondrial DNA tests, among other requests. ${ }^{132}$

In addition to the cases with DNA analysis, seven involved ballistics, three involved cell phone records, two involved blood spatter comparison, two involved fiber comparison, and one each involved arson analysis, analysis of burns from a curling iron, a bite mark comparison, fingerprint, hair, serology,

127. Bill McKleway, Man Sentenced in Deaths of Uncle, Cousin, Richmond Times-Dispatch (Apr. 24, 2007, 1:08 AM), http://www.richmond.com/news/article_4b5dfead-ddd3-5895-8c58-ed25c493579f. html?mode $=$ print $[$ https://perma.cc/TZD2-MLTX].

128. James Trial Transcript, supra note 120 , at 250-51.

129. See Morva v. Commonwealth, 683 S.E.2d 553, 557 (Va. 2009).

130. Associated Press, Va. Justices Uphold Serial Killer's Death Sentence, Richmond Times, (Jan. 14, 2012, 12:00 AM), http://www.richmond.com/news/article_9d7b2240-d307-5c37-84bd-31767329349 d.html [https://perma.cc/Q3F6-NXCZ]. The lawyers argued post-conviction that a portion of the test results indicate that another person was involved and that counsel's failure to ask a DNA expert to review that information was ineffective assistance of counsel. See Prieto v. Warden, 748 S.E.2d 94, 99 (Va. 2013).

131. Trial Transcript at 95, Commonwealth v. Shanklin, CR05001066-00 (Va. Cir. Ct. City of Hampton, Feb. 8, 2007) [hereinafter Shanklin Trial Transcript]

132. Lawlor v. Commonwealth, 738 S.E.2d 847, 859, 872-74 (Va. 2013) ("The court repeatedly granted Lawlor's successive requests for additional DNA testing, despite the fact that Lawlor admitted participating in the murder and the overwhelming consistency of the forensic evidence recovered ...."). 
and shaken baby diagnosis. Some of those less precise forms of forensics were delivered with seeming certainty at trial. For example, in one trial the ballistics testimony was presented as follows in the closing arguments: "When I say it's a ballistic match, the round that was found in his apartment, the ballistics that were taken from these men matched to the exclusion of every other weapon on the planet." The prosecutor added, "No mistake. No room for doubt."133 That testimony was not accurate, and the National Academy of Sciences Report in 2009 highlighted how such unequivocal statements cannot be made in ballistics and a wide range of traditional forensics. ${ }^{134}$

\section{Confessions}

Eight of the twenty recent cases involved confessions or admissions to law enforcement. Six involved custodial confessions and two others involved inculpatory statements to law enforcement. This is not surprising. Confessions have been quite important in death penalty cases and death eligible cases, whether they are custodial interrogations or statements to codefendants or informants, because there often are no eyewitnesses or other direct evidence of what happened at the crime scene. Professor John J. Donohue, in his study of the Connecticut death penalty, found that $59 \%$ of the death eligible murders since 1973 involved confession statements made to the authorities and $43 \%$ involved incriminating statements to third parties. ${ }^{135}$ The classic study of the Georgia death penalty, lead by Professor David C. Baldus, found that $29 \%$ of cases in a sample of 1,066 murder and voluntary manslaughter cases involved incriminating statements by the defendant or a co-perpetrator. ${ }^{136}$ More coercive interroga-

133. Trial Transcript at 51, Commonwealth v. Andrews, Nos. 63746-55, 63774-87 (Va. Cir. Ct. Prince William Cty. July 17, 2007) [hereinafter Andrews Trial Transcript].

134. Comm. on Identifying the Needs of the Forensic Scis. Cmty., Nat'l Research Council, Strengthening Forensic Science in the United States: A Path Forward 87 (National Academies Press 2009).

135. John J. Donohue III, An Empirical Evaluation of the Connecticut Death Penalty System Since 1973: Are There Unlawful Racial, Gender, and Geographic Disparities?, 11 J. EmpiRICAL LeGal Stud. 637,655 n.35 (2014) (describing how 121 of the 205 death eligible cases involved confession statements to the authorities, while 88 involved incriminating statements to a third party). Of the nine death sentences in Connecticut since 1973, five involved confession statements; three involved selfincriminating statements to third parties.

136. David C. Baldus et al., Equal Justice and the Death Penalty: A Legal and Empirical ANALYSIS 549, 562 (1990). Descriptions of evidence was not a main focus of the study, and strength of evidence data was not coded in the first of the two studies examining procedural reform, which focused on cases in which there was a murder conviction, and where therefore the evidence was presumably stronger. $I d$. at 477 n.72. However, defendant cooperation with authorities, which included confession, was associated with death sentencing. Id. at 73 tbl. 1; see also id. at 193 n.44. A study of the death penalty in Maryland found that $18 \%$ of the cases involved a "full confession to first-degree murder" and that $6 \%$ involved a "full confession to second-degree murder," while $15 \%$ involved a "full confession to aggravating circumstances;" over $9 \%$ of the cases involved a jailhouse informant. RAYMOND PATERNOSter et al., An Empirical Analysis of Maryland's Death Sentencing System with Respect to the INFLUENCE OF RACE AND LEGAL JURISDiCTION, tbl. 9, http://www.aclu-md.org/uploaded_files/0000/0376/md death_penalty_race_study.pdf [https://perma.cc/A9C8-6JA5]. On the effect of the defendant making a full confession on death sentencing in Maryland, see $i d$. at tbls. $11 \mathrm{~A}, 11 \mathrm{E}, 12 \mathrm{~A}, 12 \mathrm{E}, 13 \mathrm{~A}, 13 \mathrm{~F}$. 
tion tactics may be used in death penalty investigations. Professor Sam Gross has described how police may be far more intent on conducting lengthy and coercive interrogations in capital cases. ${ }^{137} \mathrm{I}$ have found that half, or ten of the twenty DNA exonerations of persons who have been sentenced to death nationwide involved false confessions. One of those cases was that of Earl Washington Jr., but despite the prominence of that case in Virginia, there have been no efforts to improve the quality of interrogations or to require recording of interrogations in the state. ${ }^{138}$

These capital confessions were not all recorded. Of the six cases involving custodial confession statements, only two were entirely recorded, and one other was partially recorded. In William Shanklin's case, the detective admitted that Shanklin had responded "No," when asked if he had committed the acts leading to the child's death. ${ }^{139}$ When asked why the interrogation was not recorded, the detective said, "Um, at that stage we did not have recording devices in interviews room. We now do." ${ }^{40}$ In Ricky Javon Gray's case, the detective said he took a written statement, a short one that included a series of details about the crime scene and the murders, but did not audio or video record a statement because "Gray said he was not comfortable doing that." ${ }^{141}$ The failure to record those interrogations may have resulted in more prolonged litigation about guilt. Compare the case of Marcus Garrett, in which the interrogation was apparently recorded and where he later pleaded guilty to capital murder. ${ }^{142}$

In Berman Justus' case, a portion of an interrogation was recorded, but in it he repeatedly said, "I don't remember shooting ... I don't remember shooting." Police kept asking him about statements allegedly made during unrecorded questioning at the crime scene-“You don't remember telling the deputy that you shot your wife and the gun was in the car"- -but received no clear response regarding that unrecorded statement. ${ }^{143}$ Justus said the same thing at trial, that he did not remember any shooting, and also that he saw himself as doing the work of God, "to take out the most evil people in the world," particularly since

137. Samuel R. Gross, The Risks of Death: Why Erroneous Convictions Are Common in Capital Cases, 44 Buff. L. Rev. 469, 478-79, 485 (1996) (noting that "false confessions are a much more common cause of errors for homicides than for other crimes"). In the "Death Row Ten" cases whose exonerations accompanied the end of the Illinois death penalty, all ten alleged their confessions were due to police torture. Welsh S. White, Confessions in Capital Cases, 2003 U. ILL. L. Rev. 979, 988 n.52.

138. Brandon L. Garrett, Interrogation Policies, 49 U. Rich. L. Rev. 895, 899 (2015).

139. Shanklin Trial Transcript, supra note 131, at 270-71 (Feb. 6, 2007).

140. Id. at $90,97$.

141. Trial Transcript at 638, Commonwealth v. Gray, CR 6F00698-702 (Va. Cir. Ct. City of Richmond, Aug. 16, 2006).

142. Duane Bourne, Man Pleads Guilty in Triple Slaying in Beach, Could Face Death, VIRGLNIANPILot (June 28, 2008), http://pilotonline.com/news/local/crime/man-pleads-guilty-in-triple-slayings-inbeach-could-face/article_c05e7463-062e-5c35-aba0-8d22c3b6f955.html [https://perma.cc/H67NQYDL]

143. Interview by Sergeant Les Cash, Greene Cty. Sheriff's Office with Berman Justus, in Stanardsville, Va. (Nov. 1, 2003). 
"Dave at Wendy's, Captain Kangaroo and Mr. Rogers" had died. ${ }^{144}$ The judge, at the bench trial, found those "statements and conduct" reported by the officers at the crime scene, together with circumstantial evidence such as the "[d]efendant's ownership of the gun" and "gun-shot residue" to be "powerful evidence regarding the defendant's criminal agency in terms of the shootings." 145 And in Mark Lawlor's case, he did not confess in police custody. Instead, he admitted his participation in the crime at a pre-trial hearing; at trial his lawyers said, "We told you he was involved in the murder. From the very beginning in opening statement we told you that." 146 (The defense argued that he was "extremely intoxicated," "went out of his mind," and "he was on crack," so lacked intent). ${ }^{147}$ What was surprising, though, was that such cases were the exceptions to the rule, and that instead, even in capital cases, police so often failed to record entire interrogations, giving the defense cause to challenge the accuracy of the confession statements.

\section{Informants}

In addition to the custodial confession statements and statements to police, many others were reported to have made statements to informants of one kind or another. Twelve of the twenty cases had informants or other cooperating witnesses or co-defendants. A few were jailhouse informants, but most were alleged accomplices or co-defendants that were cooperating in order to avoid the death penalty and to obtain leniency from prosecutors. In some cases, the defendants argued that jailhouse informants had lied; for example, Thomas Porter's lawyer argued that a written jailhouse confession statement had been forged by the jailhouse informant. ${ }^{148}$ Or in the Teleguz case, the defense emphasized that the cooperating witness was the alleged killer, according to the State, hired to kill the defendant's wife: "The Commonwealth has cut a deal with the killer. The Commonwealth has cut a deal with the killer . . . there's no disputing that fact." 149 The poor discovery rules in Virginia, however, may make it comparatively difficult for the defense to shed light on what arrangements were made with cooperating witnesses or informants, or how they obtained their information.

144. Trial Transcript at 1284-85, Commonwealth v. Justus, (Va. Cir. Ct. Greene Cty. Oct. 19, 2006) [hereinafter Justus Trial Transcript].

145. Id. at 1478 .

146. Trial Transcript at 73-74, Commonwealth v. Lawlor, FE-2009-0000304 (Va. Cir. Ct. Fairfax Cty. Feb. 17, 2011) [hereinafter Lawlor Trial Transcript].

147. $I d$. at $73-74,77$.

148. Michelle Washington, Jury Finds Porter Guilty in Murder of Norfolk Police Officer, VIRGINIANPilot, (Mar. 7, 2007), http://pilotonline.com/news/local/crime/jury-finds-porter-guilty-in-murder-ofnorfolk-police-officer/article_21ebd682-ef3e-5ddf-b776-2b5654e86975.html [https://perma.cc/J6YTNJXT].

149. Teleguz Trial Transcript, supra note 115, at 39 (Feb. 7, 2006). 


\section{Eyewitnesses}

Seven of the twenty capital cases in Virginia since 2005 had eyewitnesses. In a few cases, these eyewitnesses were victims who survived the murder and said they could identify the culprit, such as in the Jason Andrew James case (where the eyewitnesses were relatives who knew him well) or witnesses who saw the defendant shortly after the murder. In Ted Carter's case, the defendant pleaded guilty to capital murder, where a number of police officers were watching a planned drug-sale operation and arrested him promptly at the murder scene. In other cases, eyewitnesses saw the murderer under difficult and stressful circumstances. For example, in Thomas Porter's case, a large group of witnesses saw Porter in a confrontation with a police officer, but under varying conditions; some heard or saw the gunshot that killed the officer, some saw Porter flee the scene or said they saw Porter leave an apartment to buy drugs and heard shots shortly thereafter. ${ }^{150}$ In the Teleguz case, perhaps reflecting the quite limited discovery rules in Virginia, the defense complained that it was not until after the guilt phase that they obtained the actual information about who was present in the lineup; three of the four fillers were Hispanic, whereas the defendant was white; they argued this was an "obvious" "unduly suggestive lineup."151 The identifications were also limited, if they could be called identifications; police said one eyewitness was "around seventy percent" sure and "was not one hundred percent." 152 In general, the eyewitness evidence in these capital cases was often not particularly strong; in addition, many police agencies in Virginia have long failed to use best practices for conducting lineups, which can also impact the reliability of any identifications. ${ }^{153}$

\section{CAPITAL SENTENCING IN VIRGINIA}

"He'll die in jail, that's the bottom line," said Joshua Andrews' defense attorney. ${ }^{154}$ "We're going to ask you for mercy.... We're going to ask you to have him spend the rest of his life in a 6-by-8 cell." The prosecutor responded, "He's more dangerous, more violent, more cold and calculated than he has ever been in his life." 155 Then he went even farther than that: "You are in all likelihood now looking at the single most dangerous person you ever have or ever will encounter in your life." 156 The prosecutor called him a "killing

150. Porter v. Commonwealth, 661 S.E.2d 415, 420-22 (Va. 2008).

151. Teleguz Trial Transcript, supra note 115, at $91-92$ (July 18, 2006).

152. Id. at 249 (Feb. 7, 2006).

153. See Brandon L. Garrett, Eyewitness Identifications and Police Practices: A Virginia Case Study, 2 V.. J. CRıм. L. 1, 12-14 (2014).

154. Maria Glod, Va. Man Convicted in Fatal Shootings, WAsH. Post (July 25, 2007), http://www. washingtonpost.com/wp-dyn/content/article/2007/07/24/AR2007072401025.html [https://perma.ce/ 9LEE-56E8].

155. Id.

156. Andrews Trial Transcript, supra note 133 , at 41 . 
machine" and told the jury to "turn this machine off." "157

From the defense perspective, simply asking for mercy is not enough. It is now well understood that the sentencing phase of a death penalty trial requires far more of the defense. The defense must present "mitigation" evidence, or any evidence which can "humanize the client in the eyes of those who will decide his fate," as Professor Eric M. Freedman puts it. ${ }^{158}$ This work is "arguably the central ... duty of counsel in a capital case," one which "pervades the responsibilities of defense counsel from the moment of detention on potentially capital charges to the instant of execution."159 The Virginia statute notes that mitigation may broadly include "the history and background of the defendant, and any other facts in mitigation of the offense." 160 And in the Andrews case, the defense presented evidence through multiple experts that Andrews experienced a "perfect storm," according to treating psychiatrists, where he had been badly burned as a child, had a mentally ill mother, and developed Attention Deficit Hyperactivity Disorder, Post-Traumatic Stress Disorder, and Tourette's Syndrome as a child, among his mental illness problems. ${ }^{161}$

Unlike at the guilt phase, where evidence about the crime scene investigation, interrogations, eyewitnesses, or forensics is largely all in the hands of law enforcement and prosecutors, the sentencing phase shifts the ball to the defense's court. Mitigation evidence is evidence that the defense can collect on its own-but it takes resources to do so-and it is evidence that the defense can and should begin to investigate from the moment the case is assigned, and not just on the eve of trial. It is at the sentencing phase that capital defenders can shine, and it is at the sentencing phase that the biggest changes were observed in these Virginia capital trials. Many of the cases in which life sentences were imposed involved a "battle of the experts" at which the defense presented, apparently quite effectively, expert evidence in mitigation.

As noted, the sentencing phase was an average of four days long, just slightly less than the average guilt phase, which averaged five days long. ${ }^{162}$ In some of the recent cases, the sentencing phase was longer than the guilt phase. This increase in sentencing hearing length can be accounted for largely by an increase in the complexity of the case put on by the defense. The defense put on a far more substantial case at sentencing than the prosecution, on average. The cases averaged 11.5 prosecution witnesses and 15.1 defense witnesses, with the

157. Id. at 56, 59 (Aug. 2, 2007).

158. Freedman, supra note 79 , at 664 .

159. Id.

160. VA. Code Ann. \$ 19.2-264.4(B) (West, Westlaw through end of the 2016 Reg. Sess.).

161. Andrews Trial Transcript, supra note 133, at 171-72 (Aug. 1, 2007).

162. See Appendix A (listing number of days for each phase in each trial). For these purposes, partial days were rounded up to a day. However, trial days included only trial days at which witnesses testified or at which opening or closing arguments were given. Motion hearing days were not counted, nor were days during which the jury deliberated, because the goal was to measure, if only quite roughly, the efforts by trial attorneys to put on live testimony before the fact finder. 
defense retaining on average twice as many experts as the prosecution (1.5 defense experts to the prosecution's average of .8 experts).

The table below displays the length in days of those trials, listed by year; the length of sentencing hearings has generally increased over time. Cases in which a death sentence was imposed are indicated in black and cases in which there was a life sentence are indicated in gray.

\section{Figure 5: Sentencing Phase (in Days) in Capital Trials in Virginia, 2005-2015.}

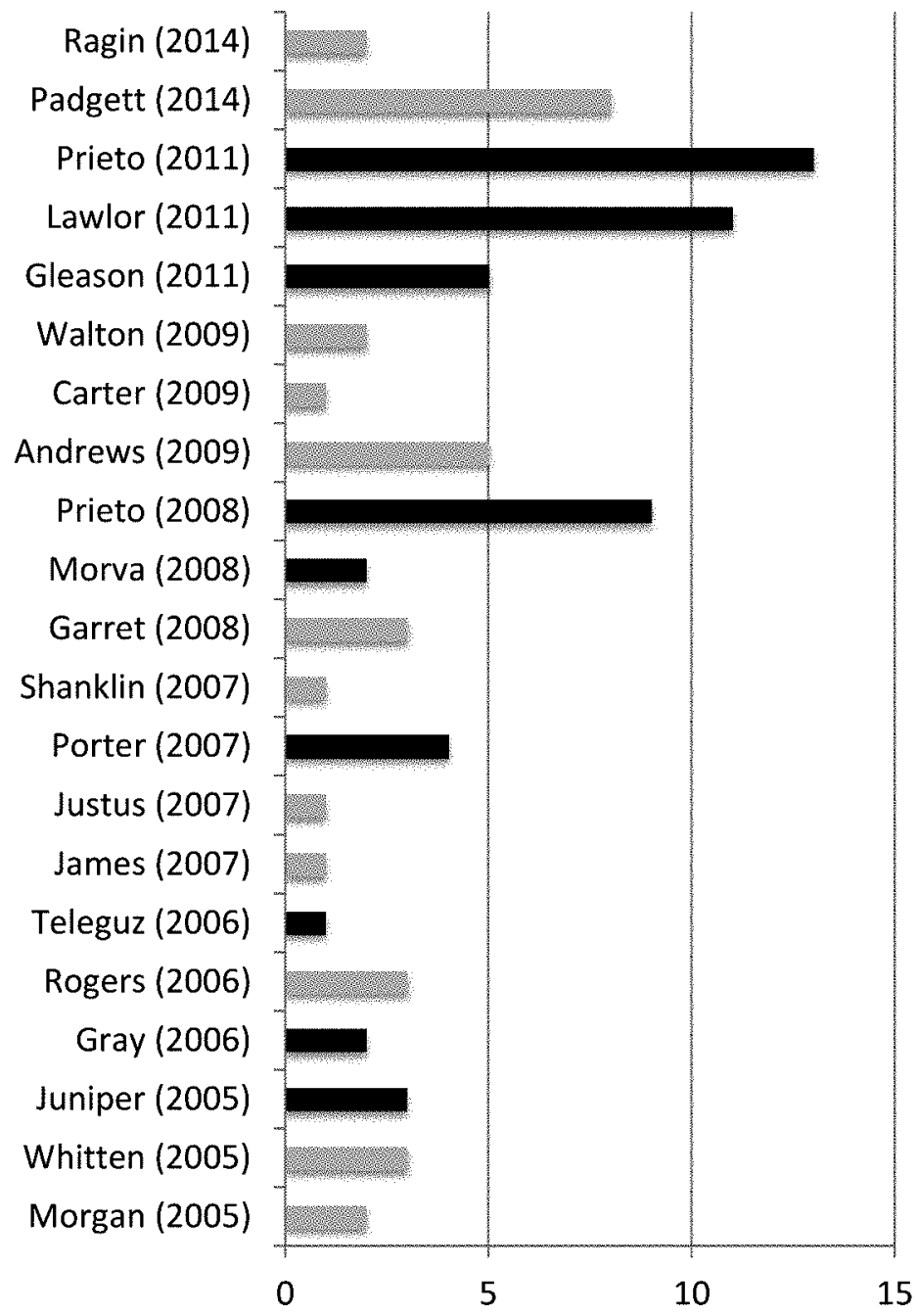

1. Data on Recent Capital Trials

The judge seemed genuinely conflicted and "shift[ed] in his seat," in the death penalty case of Carey Shane Padgett, stating: "It's an awesome 
power... depriving a man of his life and liberty. It's a big deal,' he said, shifting in his seat. 'I can't undo what's been done.", 163

The defense lawyer argued, "Look at the arc of the life that Mr. Padgett has led. ... We know he had an issue at a very young age... . A person who is so damaged that they don't understand remorse, that doesn't understand emotion-I would suggest that diminishes moral culpability." ${ }^{64}$ After a moment of silence, he added: "Can it give rise to mercy? ... I ask only for the modicum of mercy of a life sentence." 165

The prosecutor responded: "What mercy did he show... He showed no mercy at all." Ultimately, the judge decided to grant a life sentence. ${ }^{166}$

The sentencing phase may be particularly expert-dependent on the defense side, particularly related to mental health and intellectual disability claims. ${ }^{167}$ At the sentencing phase, the difference between skilled death penalty lawyers and less experienced lawyers was often apparent in their handling of mitigation evidence, as they try to make the case for a life sentence. The defense may explore the defendants' background to show why this person should not be executed, why this person was prone to violent impulses, or why this person does not pose a future danger to others. Each of those uses of mitigation evidence, beyond negating the aggravating factors, is highly important, and they overlap. Moreover, effective presentation of mitigation evidence may involve lay witnesses as well as experts. ${ }^{168}$

The sentencing phase at these recent Virginia capital trials was often longer than the guilt phase (when there was a guilt phase). The average sentencing phase was four days long. On average, during sentencing the defense called more witnesses than the prosecution, calling an average of fifteen witnesses as compared to eleven witnesses for the prosecution. The defense called twice as many experts, averaging 1.5 experts during sentencing to .8 for the prosecution. In contrast to the cases involving the RCD offices and a handful of highly experienced capital defense lawyers, trials involving court-appointed lawyers were on average shorter. The average number of witnesses called at sentencing for trials involving the RCDs was eighteen, with an average sentencing hearing

163. Chase Purdy, Padgett Avoids Death Penalty, Sentenced to Five Life Terms, Ronnoke Times, (Mar. 26, 2014, 1:07 PM), http://www.roanoke.com/news/crime/roanoke_county/padgett-avoids-deathpenalty-sentenced-to-five-life-terms/article_2b0c21cc-b509-11e3-ac68-001a4bcf6878.html [https://perma. cc/7WRG-C244].

164. Id.

165. Id.

166. Id.

167. See generally Scott E. Sundby, The Jury as Critic: An Empirical Look at How Capital Juries Perceive Expert and Lay Testimony, 83 VA. L. REv. 1109 (1997).

168. Scott E. Sundby, The True Legacy of Atkins and Roper: The Unreliability Principle, Mentally Ill Defendants, and the Death Penalty's Unraveling, 23 WM. \& MARY BцL RTs. J. 487, 513-19 (2014) (describing the many challenges in effectively representing mentally ill capital defendants, including to ensure that jurors do not view mental illness as a "two-edged sword"). 
length of over four days. This marks a remarkable shift towards robust defense litigation of mitigation evidence in Virginia capital trials.

Compare the case of Mark Lawlor, found guilty of an extremely brutal murder in a five-day guilt phase that revolved around forensic evidence, including DNA and blood spatter evidence. ${ }^{169}$ Lawlor was represented by four lawyers from one of the RCD offices. Lawlor's sentencing phase trial was eleven days long, compared to a five-day guilt phase. ${ }^{170}$ The prosecutors called eleven witnesses and Lawlor's lawyers called forty-nine witnesses. Lawlor's lawyers emphasized that he was a compliant prisoner who did not pose a danger of future violence, and they presented lay witnesses on the issue of future dangerousness (discussed further below) as well as testimony of two experts concerning future dangerousness. ${ }^{171}$ Another example is the case of Xenia Morgan, where the result was a life sentence, and the defense lawyers presented experts on her low IQ, alcohol and drug abuse, frontal lobe damage, and a psychologist testified about the relationship between alcohol use and such brain damage. ${ }^{172}$

One recent trial involved a pro se defendant, who asked that the capital defender's office be removed from the case. The psychologist asked by the state to examine Robert Gleason Jr. concluded: "There is absolutely no evidence whatsoever that his decision to waive counsel is anything other than voluntary. It certainly does not arise from a delusion or psychosis." 173 Instead, it was "part and parcel of his commitment to autonomy." ${ }^{174}$ In contrast, the Institute of Law, Psychiatry \& Public Policy at the University of Virginia concluded that Gleason's "current anger and dismay at his attorneys is compromising his ability to work proactively in his own defense," but nonetheless he did "possess[] those capacities necessary for trial competency." 175

Representing himself pro se, Gleason pleaded guilty to capital murder, but then had a five-day sentencing hearing at which both sides called many witnesses: he called twenty-four witnesses and the state called thirteen. However, his questioning of witnesses was, as one would expect, different from what lawyers would have conducted. Gleason elicited testimony from prison officials, for example, that he had "definitely reset the benchmark," resulting in new

169. Lawlor v. Commonwealth, 738 S.E.2d 847, 858-59 (Va. 2013).

170. See Appendix A.

171. Lawlor Trial Transcript, supra note 146, at 88 (Feb. 23, 2011) (lay testimony regarding future dangerousness); $i d$. at 37 (Mar. 3, 2011) (lay corrections witness testified regarding dangerousness); $i d$. at 61 (Mar. 7, 2011) (testimony of psychopharmacologist); $i d$. at 18, 104 (Mar. 9, 2011) (testimony of two expert psychologists regarding future dangerousness).

172. Jamie C. Ruff, Woman Gets Life Term in Slaying, Lawyers Cited Alcohol, IQ in Enraged Killing of 70-Year-Old Victim, Richmond Times-Dispatch, July 21, 2005, at B-1.

173. Competence Evaluation at 9, Commonwealth v. Gleason, No. F11-05 (Va. Cir. Ct. Wise Cty. Apr. 21, 2011) [hereinafter Competence Evaluation].

174. Id.

175. Competency to Stand Trial Evaluation at 6, Commonwealth v. Gleason, No. CR09F00279-00 (Va. Cir. Ct. Wise Cty. Mar. 17, 2010). 
security measures being taken in Virginia prisons. ${ }^{176} \mathrm{He}$ elicited testimony from an expert, a psychologist, that he was competent and was not merely seeking "celebrity." 177

Gleason testified at length, following repeated warnings from the judge that he should consult with his lawyers and that he had the right to remain silent and not incriminate himself. He admitted that his stand-by lawyers had all told him not to testify, commenting, "I'm like Jackie Gleason. I got a big mouth." ${ }^{178} \mathrm{He}$ then described in terrible detail why and how he had killed two different cellmates, saying, as to the first victim: "Did I have a choice to kill that man? Was I in any physical danger? Nope. I'm the kind of person: don't call my bluff." 179 He added, "Killed him, he was gone. Do I feel bad for it? No, not at all," and on the second murder, "Do I feel remorse for it? No."180 His attorneys made post-conviction efforts to raise, which Gleason did not, the issue of mental illness, calling this "a bizarre case where the death penalty is actually the sole motivator for the killing;" Gleason was executed in 2013. ${ }^{181}$ Such cases in which mitigation was not presented, highlight how effective defense litigation during sentencing, including use of experts, can make the difference between life and death.

\section{Mental Illness}

Early on, when the issue of mental competency is raised, a defendant may be ordered by a judge to be evaluated for competency to stand trial; in Virginia, a judge must appoint a mental health expert to assist in that determination and as to questions whether the defendant acted under "extreme mental or emotional disturbance at the time of the offense," or whether there were any "factors in mitigation" related to the defendant's history or "mental condition at the time of the offense." 182 Such evidence is recognized by state statute as mitigation evidence at the sentencing stage. ${ }^{183}$ More than half of these recent capital cases involved litigation regarding mental illness, which can potentially be raised in multiple ways, including as an issue of competency to stand trial, as an insanity defense at the guilt phase, and as mitigation evidence at sentencing. Of the twenty defendants that faced capital trials in Virginia since 2005, nine raised

176. Trial Transcript at 149, 155-56, Commonwealth v. Gleason, Nos. F11-55, F09-279 (Va. Cir. Ct. Wise Cty. Sept. 6, 2011) [hereinafter Gleason Trial Transcript].

177. Competence Evaluation, supra note 173, at 1706.

178. Gleason Trial Transcript, supra note 176, at 198-99.

179. Id. at 205 .

180. Id. at 206.

181. Justin Jouvenal, Va. Executes Convicted Killer Who Sought Death Penalty, WASH. Post (Jan. 16, 2013), https://www.washingtonpost.com/local/va-executes-convicted-killer-who-sought-death-penalty/ 2013/01/16/89802e00-6015-11e2-9940-6fc488f3fecd_story.html [https://perma.cc/U7KQ-2EHU].

182. VA. Code Ann. $\$ 19.2-264.3: 1$ (West, Westlaw through end of the 2016 Reg. Sess.).

183. Id. $\S 19.2-264.4$ (B) (Westlaw) (noting that factors in mitigation include that "at the time of the commission of the capital felony, the capacity of the defendant to appreciate the criminality of his conduct or to conform his conduct to the requirements of law was significantly impaired"). 
mental illness during sentencing. One additional defendant, Robert Gleason, tried to call an expert on the issue, but the judge ruled the testimony inadmissible. His lawyers later argued, as noted above, that he was severely mentally ill, but he was nonetheless permitted to represent himself at trial, sought his own execution, and did not contest the State's expert evidence.

A "double-edged sword" is a metaphor sometimes used for evidence at the mitigation phase of a capital trial, although it is a metaphor that may be highly misleading. ${ }^{184}$ As with other types of mitigating evidence, evidence of mental illness can show lack of responsibility for a murder, but also likelihood to commit future murders.

In Berman Justus' case, the metaphor was a little more literal than usual. The battle of the experts began before trial regarding the initial question of his competency to stand trial, and it continued through trial and sentencing. Justus was evaluated at Central State Hospital, after an initial competency report in spring 2004, two-and-a-half years before he stood trial. The state Department of Mental Health evaluated him, and although earlier experts from the Institute of Law, Psychiatry and Public Policy at the University of Virginia had found him to be a person who would have "significant difficulties grasping necessary information" to make "rational decisions," and early evaluations suggested that he was "not competent to stand trial" because "his thinking was psychotic," the Department's evaluator ultimately concluded that "Mr. Justus eventually responded well to treatment including medications" and though diagnosed as schizophrenic and bipolar, he was found competent to stand trial. ${ }^{185}$ At the guilt phase, Justus testified, as noted, about how he saw himself as doing the work of God, to eliminate the forces of evil. He had found his name in the Bible and dreamed about "[a] double-edged sword with which God intends to have the sinners slain." 186

At the bench trial, both the defense and the prosecution presented witnesses on the question of whether insanity or psychosis explained the crime. ${ }^{187}$ The prosecutors argued that there was no evidence of "being on a mission from God" until after his arrest when he met with the defense expert. ${ }^{188}$ The judge ruled that despite the contrary expert evidence, the State's psychologist "simply makes more sense in light of all of the evidence in the case," and found the evidence supported a theory of jealousy or anger, but it was "not sufficient to

184. For an important exploration of this metaphor in a detailed analysis of the uses of neuroscience evidence in criminal cases, see Deborah W. Denno, The Myth of the Double-Edged Sword: An Empirical Study of Neuroscience Evidence in Criminal Cases, 56 B.C. L. Rev. 493 (2015).

185. Evaluation of Competency to Stand Trial by Dr. Ted B. Simpson at 2-3, Commonwealth v. Justus, No. 4-125 (Va. Cir. Ct. Greene Cty. May 22, 2006); Psychological Evaluation by the Institute of Law, Psychiatry and Public Policy at 1, Commonwealth v. Justus, No. JA002309-07 (Va. Cir. Ct. Greene Cty. Sept. 8, 2005).

186. Justus Trial Transcript, supra note 144, at 1416 (Oct. 23, 2006).

187. Id. at 1284 (Oct. 19, 2006), 1405-06 (Oct. 23, 2006).

188. Id. at 1408 (Oct. 23, 2006). 
establish the defense of insanity in this case." ${ }^{89}$ At sentencing, the defense again presented its expert (the prosecution rested on its evidence presented at the guilt phase), and Justus was sentenced to life in prison. The defendant himself testified that he was "just driven all the time," and he was sure experts would have found "the seeds of psychosis before the crime."190

At sentencing, the double-edged sword favored the defense. The judge concluded that even if there were differences as to "the precise diagnosis," there was "universal agreement that the defendant is a mentally ill person" and that the experts only differed "over the degree of the illness." ${ }^{191}$ Despite denying the insanity defense and finding the defendant competent to stand trial, the mental illness evidence and "the complete lack of a history of violence, ... tips the scales in the direction of a life sentence."192 Similarly, Ted Carter did not receive the death penalty, apparently due to evidence of his schizophrenia, although he had pleaded guilty to capital murder. ${ }^{193}$

The treatment of mitigation evidence as "double-edged" may simply be false. ${ }^{194}$ The current view of capital litigators is that mitigation evidence can only help to present as detailed evidence as possible concerning the mental state and limitations of a defendant. Now that lawyers have better access to experts on this subject, the results are striking.

\section{Intellectual Disability}

In 2002, the U.S. Supreme Court ruled in Atkins v. Virginia, that intellectually disabled individuals may not be executed. ${ }^{195}$ In Atkins, the Supreme Court emphasized how: "Because of their disabilities in areas of reasoning, judgment, and control of their impulses, however, they do not act with the level of moral culpability that characterizes the most serious adult criminal conduct." 196 Atkins involved a battle of the experts, with "extensive, but conflicting" testimony from two experts. ${ }^{197}$ The defense expert (who had testified often for the prosecution and the defense in Virginia) concluded that Atkins was "mildly mentally retarded, with an IQ of 59," which "would automatically qualify for Social Security disability income." 198 The prosecution expert, who did not conduct any intelligence tests, but interviewed Atkins twice, concluded that

189. Id. at 1476 .

190. Id. at 1582 (Jan. 16, 2007).

191. Id. at 1589.

192. Id. at 1591 .

193. Kristin Davis, Man Gets Life Sentence in Murder of Virginia Beach Detective, VIRGINIAN-PLOT (Feb. 17, 2011), http://pilotonline.com/news/local/crime/man-gets-life-sentence-in-murder-of-virginiabeach-detective/article_149b5368-1385-5de0-8ecd-f702b2b87f51.html [https://perma.cc/6KM4BQEU].

194. Regarding reliance on the double-edged sword metaphor, see Denno, supra note 184.

195. 536 U.S. 304,304 (2002).

196. Id. at 306 .

197. Atkins v. Virginia, 534 S.E.2d 312, 320 (Va. 2000).

198. Atkins, 536 U.S. at 308-09, 309 n.5. 
Atkins was of "average intelligence, at least." 199 What the Supreme Court did not do was carefully set forth how states should define intellectual disability.

In response to the Atkins decision, in 2003, Virginia enacted a new definition of intellectual disability, noting that assessments shall be conducted in "conformity with accepted professional practice," and the issue "shall be determined by the jury" in capital cases in which a jury is sentencing, with the defendant bearing the burden to show mental retardation by a preponderance of the evidence. ${ }^{200}$ Virginia also enacted a revised statute providing for expert assistance in evaluating potential intellectual disability. ${ }^{201}$ Of course, evidence of intellectual disability is also relevant, potentially, to challenge the depravity of mind aggravating circumstance. The Virginia statute had also provided that intellectual disability be defined as "at least two standard deviations below the mean," typically a score of 70 or below on an IQ test; ${ }^{202}$ the Supreme Court returned to that issue in Hall v. Florida, ruling that strict IQ cut-offs may not be used. $^{203}$

The Atkins procedures have been invoked time and again in the years since. At least three of these recent capital trials involved claims of intellectual disability. In the Prieto case, there was a hung jury initially at a hearing regarding the issue of intellectual disability - an Atkins hearing. ${ }^{204}$ A range of defense experts and days of cross-examination of prosecution witnesses occurred at a quite extensive hearing. Prieto later appealed, challenging whether the jury improperly considered a rigid IQ cut-off in evaluating intellectual disability. Prieto had IQ scores of 66 and 73, and Virginia had an effective threshold of 70. The case was reversed for a still more lengthy hearing on the question (the longest sentencing trial in Virginia in the past decade, and certainly one of the longest ever held in Virginia), after which he was again sentenced to death; ${ }^{205}$ as noted, he was executed in October $2015 .{ }^{206}$ It is troubling that in an era with so few death sentences, prosecutors continue to seek the death penalty so often against persons with intellectual disabilities.

199. Id. at 309 .

200. VA. Code Ann. \$ 19.2-264.3:1.1 (West, Westlaw through end of the 2016 Reg. Sess.).

201. Id. $\$ 19.2-264.3: 1.2$ (Westlaw). Additional legislation provided that no statements by the defendant as part of such mental health evaluations may be admissible, except when relevant to mitigation raised by the defense. $I d$. $\S 19.2-264.3: 3$ (Westlaw).

202. Id. § 19.2-264.3:1.1 (Westlaw).

203. 134 S. Ct. 1986, 2000 (2014); see also Richard J. Bonnie \& Katherine Gustafson, The Challenge of Implementing Atkins v. Virginia: How Legislatures and Courts can Promote Accurate Assesments and Adjudications of Mental Retardation in Death Penalty Cases, 41 U. Rich. L. Rev. 811, 844-45 (2007).

204. Frank Green, Judge to Rule Soon on Appeal Dismissal in Prieto Death Row Case, Richmond Times-DispaTch (Aug. 16, 2014), http://m.richmond.com/news/ndrews/article_c35978da-f19a-11e3-85b 8-001a4bcf6878.html?mode=jqm [https://perma.cc/GW2N-7G79].

205. Id.

206. See Jackman, Triple Murderer, supra note 108. 


\section{Background Evidence}

Mitigation evidence can also include evidence of the defendant's age, difficult upbringing, childhood abuse and violence, post-traumatic stress, "subaverage intellectual functioning" short of intellectual disability, and other nonmedical evidence. ${ }^{207}$ The presentation of such evidence can help to humanize the defendant, and it can be presented not only through experts, but quite effectively through family and lay witnesses describing the defendant's background.

In the Andrews case, one of his attorneys later remarked that in ten years of capital representation, Andrews had "suffered some of the worst trauma and abuse and poverty and neglect of any of the clients that I've ever represented." 208 His father had been sentenced to death in Texas. He had been badly burned when locked in a shed that was set on fire when he was eight years old. The trial court would not let in a poem that Andrews had written:

I've been struggling in this smokeless fire for 19 years, over my lifetime I shed my pain through unwanted tears, been through hell back burning since adalescence (sic), will I enter heaven or return for final destination, born into a world filled with complete darkness, didn't understand love so my hear[t] hardened, forereal forreal [sic]. ${ }^{209}$

The Virginia Supreme Court later found that to be in error and reversed the conviction on other double jeopardy grounds; he then entered a plea resulting in a life sentence. ${ }^{210}$

In the Prieto case, his lawyers put on detailed evidence of a brutal childhood, up until the age of fifteen, in El Salvador, where he witnessed atrocities during the civil war, and then gang violence in Los Angeles upon moving there. ${ }^{211}$ The sentencing hearing was lengthy, and following an appellate reversal, a still more lengthy resentencing hearing was conducted.

207. VA. Code Ann. \& 19.2-264.4(B) (West, Westlaw through end of the 2016 Reg. Sess.) (noting that factors in mitigation include that "the defendant has no significant history of prior criminal activity" and "the age of the defendant at the time of the commission of the capital offense").

208. Brian McNeill, A Murder is Solved and a Man Avoids Death, Thanks to Unusual Deal Brokered by Clinic Professors, UNIv. of VA. ScH. OF LAw (May 31, 2012), http:/www.law.virginia.edu/html/news/ 2012_sum/andrews.htm [https://perma.cc/K4LG-3YP6].

209. Dena Potter, Va. Supreme Court Overturns Death Sentence, NBC WASH. (Sept. 16, 2010, 9:01 PM), http:/www.nbcwashington.com/news/local/Va-Supreme-Court-Overturns-Death-Sentence-103101 709.html [https://perma.cc/82PG-QFES]; Andrews Trial Transcript, supra note at 133, at 111 (July 30, 2007).

210. Associated Press, Va. Inmate Escapes Death in Plea Deal, WBOC (May 31, 2012, 3.53 PM), http://www.wboc.com/story/18669161/va-inmate-escapes-death-sentence-in-plea-deal [https://perma.cc/ 7MFV-KPA8].

211. See Jackman, Prieto Sentenced to Death, supra note 108. 


\section{Future Dangerousness}

One of the two aggravating factors in Virginia that permit the death penalty to be imposed is that there is a probability that the defendant will commit future criminal violence that would constitute "a continuing serious threat to society." 12 A Capital Jury Project study of Virginia capital jurors found that Virginia capital jurors focused their attention on a defendant's future dangerousness, and a troubling number incorrectly believed that having found future dangerousness, they were required to return a death sentence. ${ }^{213}$ The second aggravating factor regarding the vileness of the crime is inherently vague; in contrast, one might think that the first factor, future dangerousness, would be more concrete because there is some empirical research on characteristics of violent recidivist offenders. However, since 1995, the question has become an inherently confounded one, despite its importance to capital sentencing in Virginia, because the alternative to the death penalty is now life without parole. And the real question is whether a person will be dangerous when confined for life in prison (the likelihood that a convict will commit murder in prison is vanishingly low). ${ }^{214}$ That question, however, is not one that the Virginia Supreme Court has permitted to be posed to the jury.

Pre-1995, the future dangerousness testimony did not have to take account of life without parole. In Derek Barnabei's trial in 1995, the prosecutor put it this way, without relying on any expert evidence: "The best predictor of future conduct, ladies and gentlemen, is past conduct." 215 The Virginia Supreme Court has also long supported the use of a wide variety of evidence to satisfy that factor, ranging from drug use, ${ }^{216}$ to tampering with a vending machine, ${ }^{217}$ to possession of stolen property. ${ }^{218}$ Perhaps for that reason, there has rarely been a battle of future dangerousness experts, as is common in Texas. ${ }^{219} \mathrm{I}$ did find such testimony in an older trial, that of Dexter Lee Vinson. The state put on an expert who claimed, after "reading and going over the material that was presented to

212. VA. Code Anv. \$ 19.2-264.2 (West, Westlaw through end of the 2016 Reg. Sess.).

213. Garvey \& Marcus, supra note 105 , at 2086-87.

214. See, e.g., Jonathan R. Sorensen \& Rocky L. Pilgrim, An Actuarial Risk Assessment of Violence Posed by Capital Murder Defendants, 90 J. CRIM. L. \& CRIMINOLOGY 1251, 1257, 1262 (2000) (finding $0.2 \%$ rate among Texas murder convicts); see also Erica Beecher-Monas, The Epistemology of Prediction: Future Dangerousness Testimony and Intellectual Due Process, 60 WASH. \& LEE L. REv. 353,363 (2003) (discussing the advantages of using statistically analyzed data to predict future dangerousness).

215. Trial Transcript at 2532, Commonwealth v. Barnebei, No. 941302F08B (Va. Cir. Ct. City of Norfolk June 14, 1995).

216. Quesinberry v. Commonwealth, 402 S.E.2d 218, 227 (Va. 1991).

217. Strickler v. Commonwealth, 404 S.E.2d 227, 236 (Va. 1991).

218. King v. Commonwealth, 416 S.E.2d 669, 678 (Va. 1992).

219. See, e.g., Coble v. State, 330 S.W.3d 253, 277-79 (Tex. Crim. App. 2010) (finding an expert witness's testimony about future dangerousness inadmissible because the expert did not employ scientifically reliable methodologies); see also Brief for Capacity for Justice et al. as Amici Curiae In Support of Petitioner at 9-11, Coble v. State, No. 10-1271 (U.S. filed May 18, 2011), 2011 WL 1979653) (listing recent Texas cases involving future dangerousness testimony by the same expert). 
me, in other words, the police repots, the autopsy report, the various witness reports and [other] information with respect to Mr. Vinson's prior criminal convictions," that he could predict that "there is at least a fifty percent chance of another violent offense in the next five years."220 What methods or research could possibly support such a seemingly precise estimate was not at all clear. The expert seemed to think that Vinson "scores pretty high" on various "parameters" and perhaps should have left it at that. ${ }^{221}$

The Virginia Supreme Court has ruled that the future dangerousness question is whether the person might be dangerous to society as a whole, and not only in prison. ${ }^{222}$ As a result, the Virginia courts have long been hostile to defense efforts to present expert evidence regarding the unlikely chance that a defendant could murder again while in high-security custody. ${ }^{223}$ For example, in the case of Thomas Porter, his lawyers tried to introduce testimony by a leading expert on prison violence risk, Dr. Mark Cunningham. ${ }^{224}$ The judge refused, stating that the Virginia Supreme Court had "consistently upheld the denial of use of public funds for such an expert," since it was not "proper mitigation evidence." 225 The judge instructed the jury, when his lawyers argued that he was highly unlikely to commit violent crimes in the "society" of prison, that: "Society is everything. Everybody, anywhere, anyplace, anytime."226 The Virginia Supreme Court found it proper to exclude that testimony, relying on its prior future dangerousness decisions, because it was not properly tailored to the defendant's own "prior history, conviction record, and the circumstances of the crime." 227 After all, what is relevant is whether the convict could be dangerous in "society," based only on prior history, even though they would be sentenced to life in prison and were not permitted to explain why they are not a continuing serious threat in a prison environment. ${ }^{228}$ There is real variation between judges. In Marcus Garrett's case, for example, the trial judge requested an expert report from Dr. Cunningham, although the defense and the prosecution had already both retained experts (both of whom concluded Garrett did not pose

220. Trial Transcript at 1020-22, Commonwealth v. Vinson, No. 97-1789 (Va. Cir. Ct. City of Portsmouth Dec. 9, 1998).

221. Id. at 1022 .

222. Lovitt v. Commonwealth, 537 S.E.2d 866, 879 (Va. 2000).

223. See, e.g., Mark D. Cunningham, Dangerousness and Death: A Nexus in Search of Science and Reason, 2006 AM. Psychologist 828, 832 (finding that the rate of violanet crime in prisons is "quite low" despite a "concentration of individuals whose community conduct had been recurrently criminal and violent").

224. Porter v. Commonwealth, 661 S.E.2d 415, 436 (Va. 2014).

225. Id. at 423 .

226. Porter v. Davis, No. 3:12-CV-550-JRS, 2014 WL 4182677, at*2 (E.D. Va. Aug. 21, 2014).

227. Porter, 661 S.E.2d at 442 . The Virginia Supreme Court approved the exclusion of the same expert in Morva v. Commonwealth, 683 S.E.2d 553, 563-64 (Va. 2009). A future dangerousness expert was also excluded in the Teleguz and Juniper cases. Teleguz Trial Transcript, supra note 115, at 198-99 (July 18, 2006); Trial Transcript at 299, 399, Commonwealth v. Juniper, CR04001267-08 (Va. Cir. Ct. City of Norfolk, Jan. 5, 2005).

228. Porter, 661 S.E.2d at $441-43$. 
a future danger). ${ }^{229}$

Virginia has not adopted the Daubert ${ }^{230}$ standard regarding validity and reliability of scientific evidence, but asks more generally whether expert testimony is based on an "adequate foundation" and would assist the jury. ${ }^{231}$ Moreover, the U.S. Supreme Court in 1983 in Barefoot v. Estelle found expert psychiatric testimony on future dangerousness not per se unconstitutional; ${ }^{232}$ that standard has not been revisited based on the reliability and validity standards adopted in Daubert. These rulings are in tension with the basic principle dating back to Lockett v. Ohio that the Constitution forbids a state from "preclud[ing] consideration of relevant mitigating factors." ${ }^{233}$ Yet again, in the Andrews case, the judge rejected the defense's proposed future dangerousness testimony, stating that "empirical data" could not be presented, but only "something that's particularized to an individual[]" or how an individual "might react or not react.",234

What judges have permitted is testimony through Department of Corrections officials regarding the security arrangements in the type of prison that a capital murder convict, serving a life sentence, would experience. In Antwon Whitten's case (as in other cases, such as that of John Jose Rogers), the Chief of Operations for the Virginia Department of Corrections was called for the defense. ${ }^{235}$ The Chief of Operations testified that Whitten "would be confined to his cell" twenty-four hours a day and he "would not have group access to other inmates;" he "would only come out of the cell for outdoor recreation a minimum of five times per week for showers," non-contact visits, and medical or legal appointments. ${ }^{236}$

The lack of a criminal record need not be an obstacle; take the older, 1998 case of Bobby Wayne Swisher, where the prosecutor emphasized:

229. Trial Transcript at 431, Commonwealth v. Garrett, CR05-2976 (Va. Cir. Ct. City of Va. Beach, Oct. 3, 2008).

230. Daubert v. Merrell Dow Pharm., 509 U.S. 579,597 (1993).

231. See, e.g., Keesee v. Donigan, 524 S.E.2d 645, 647 (Va. 2000); see also Husske v. Commonwealth, 476 S.E.2d 920, 925 (Va. 1996) (describing a "particularized need" standard for indigent defense requests for appointment of expert witnesses).

232. 463 U.S. 880,904 (1983).

233. Lockett v. Ohio, 438 U.S. 586, 608 (1978) (plurality opinion). Such rulings are also in real tension with Simmons v. South Carolina, 512 U.S. 154, 162 (1994) (plurality opinion), which requires that the jury be instructed on life without parole availability. The Virginia Supreme Court has distinguished Simmons, where there is a life without parole instruction provided, and Skipper v. South Carolina, 476 U.S. 1, 4 (1986), where defendant-specific facts may be presented at sentencing. E.g., Porter, 661 S.E.2d at 441,441 n. 14.

234. Trial Transcript at 219-20, Commonwealth v. Andrews, Nos. 63746-63755, 63774-63787 (Va. Cir. Ct. Prince William Cty. Aug. 1, 2007).

235. Trial Transcript at 135-36, Commonwealth v. Whitten, CR 03001070-00, 01 (Va. Cir. Ct. Stafford Cty. June 1, 2005) [hereinafter Whitten Trial Transcript]; Rogers Trial Transcript, supra note 20, at 59 (Aug. 30, 2006).

236. Whitten Trial Transcript, supra note 235, at 135-36. 
What other factors should be considered; or may be considered? The fact that he doesn't have any criminal history? Yeah, that-that's fine. "That he has no significant history of prior criminal activity." That's one thing that can be considered. But look at the testimony. He may not have criminal convictions, but he's been in trouble all of his life; from the time he started in school, really from the time he started using drugs, at age thirteen or fourteen. He started fighting. He kept getting in trouble for fighting with other students. $\mathrm{He}$ continued that criminal activity of using drugs up through his late teens; up 'til he turned twenty. He kept doing it; kept breaking the law. He just doesn't care. He just doesn't care. ${ }^{237}$

A more recent example is the case of John "Jose" Rogers, which involved an extremely comprehensive and expert-intensive sentencing hearing over four days where he was represented by an RCD office (and which resulted in a life sentence). Rogers' lawyers presented twenty-one witnesses, compared to just five witnesses presented by the prosecutors. Their expert on the issue of future dangerousness, Dr. Cunningham again, presented testimony along lines the Virginia Supreme Court approved, opining that, based on the assumption that Rogers would be incarcerated for life in a maximum security prison, there was a "very, very low rate in general" of violence among such inmates, and Rogers' rate "[wa]s going to be significantly lower than that already low rate." 238 The expert was also permitted to describe statistics from "large scale studies that track capital offenders who are serving life sentences in prison," that show "the overwhelming majority of those inmates don't commit acts of serious violence in prison." 239 The prosecutors had to concede, on the issue of future dangerousness that, based on eight years of prison records, "He's a good prisoner. A model prisoner... [a]nd that's fine," but countered that it was still "obvious" that he would "constitute a continuing serious threat to society." 240

Ricky Javon Gray's lawyers also presented expert evidence on future dangerousness, together with an expert on child abuse, but he was still sentenced to death; the crimes involved the brutal murder of an entire family of four (and he had confessed to other uncharged murders, including that of his wife), and prosecutors described his criminal record and lack of remorse. ${ }^{241}$ Most recently, Mark Lawlor's lawyers did the same, but the trial judge once again confined the expert testimony on future dangerousness. ${ }^{242}$

Unlike those more typical cases, in the recent 2011 trial of Robert Gleason for murders that occurred in prison, the judge heavily emphasized future

237. Trial Transcript at 103, Commonwealth v. Swisher, No. 980677 (Va. Cir. Ct. Augusta Cty. Oct. 30, 1997) [hereinafter Swisher Trial Transcript].

238. Rogers Trial Transcript, supra note 20, at 171, 186 (Aug. 31, 2006).

239. Id. at 96 (Aug. 30, 2006).

240. $I d$. at 284-85 (Aug. 31, 2006).

241. The trial judge approved such testimony. Gray v. Commonwealth, 645 S.E.2d 448, 454-55 (Va. 2007).

242. Lawlor v. Commonwealth, 738 S.E.2d 847, 881, 881 n.24 (Va. 2013). 
dangerousness as the reason supporting the death sentence. The judge explained:

Despite being confined in Wallens Ridge State Prison, defendant planned and carried out the murder of his cellmate.... Following this killing, defendant was moved to Red Onion State Prison, the Commonwealth's only Level S "supermax" prison facility. There, the defendant was again able to plan and carry out the murder of an inmate... . The evidence overwhelmingly established that it is not possible to prevent future human contact with the defendant in any prison setting currently in existence. ${ }^{243}$

Gleason was representing himself pro se. In general, however, the issue of future dangerousness, like so much in the recent sentencing hearings, has been far more intensively litigated in recent years, including through expert evidence.

\section{Vileness}

The second aggravating factor recognized in Virginia is whether the murder was "outrageously or wantonly vile, horrible or inhuman in that it involved torture, depravity of mind or an aggravated battery to the victim." 244 The Virginia Supreme Court has rejected multiple challenges to that factor as unconstitutionally vague. ${ }^{245}$ As noted, seven of the post-2005 capital trials in Virginia involved two victims, two cases involved three victims and three involved four. Four of the cases involved a murder during the commission of a rape. Prosecutors understandably focused on the circumstances of the murder during both the guilt phase and during sentencing. In the case of William Morva, in which the death penalty was imposed for the killing of a police officer, the prosecutors emphasized in their opening statement: "This is a case about a prisoner who beat a deputy down, beat him unconscious, broke his face, broke his face bone, broke his nose, in the course of an escape."246

That focus was not always successful. For example, in William Shanklin's case, the prosecutor emphasized in closing arguments, "what else can you call what happened to that child? That was torture, plain and simple... It would have been far kinder to this child to put a gun to his head and pull the trigger . ..."247 The prosecutor emphasized that the death penalty should be "always reserved for the worst of the worst, but I submit to you that this is the worst of the worst."248 The defense emphasized Shanklin's good relationships

243. Sentencing Order at 2, Commonwealth v. Gleason, F09-279 (Va. Cir. Ct. Wise Cty. Sept. 8, 2011).

244. VA. Code Ann. $\$ 19.2-264.2$ (West, Westlaw through end of the 2016 Reg. Sess.).

245. Wolfe v. Commonwealth, 576 S.E.2d 471, 480 (Va. 2003); Beck v. Commonwealth, 484 S.E.2d 898, 907 (Va. 1997).

246. Trial Transcript at 673, Commonwealth v. Morva, No. 090186 (Va. Cir. Ct. Wash. Cty. Mar. 6, 2008).

247. Shanklin Trial Transcript, supra note 131, at 68-69 (Feb. 9, 2007).

248. Id. at 69 . 
with family and friends, and his lack of a prior record. ${ }^{249}$ And the defense emphasized that although the jury had found him guilty of murder, the evidence was uncertain concerning whether he or the four-year-old victim's aunt had been chiefly responsible for the abuse and neglect: "None of us in this room really know what went on in that house. He was working; she was working."250 The jury imposed a life sentence. ${ }^{251}$ Again, the more substantial mitigation evidence presented in recent capital trials appears to be making a real difference.

\section{Victim Statements}

In Virginia, as in other states, victims have a right to present statements describing the impact of a crime on the victim or the victim's family. ${ }^{252}$ Judges provide a standard form that permits victims to detail injuries - physical, psychological, and economic. In the Teleguz case, for example, the victim's father simply and movingly wrote that he: "Couldn't sleep, could not work. I still experience loss of sleep and trouble working to the present day. . . . I still can't get any of her pictures up. I don't ever want to hear anyone say goodbye." 253 Family members of victims commonly testify in person at sentencing hearings as well. At the sentencing hearing for Jason James, over seventy relatives of the victims were present (the defendant was also a relative). The victim's son said James should have received the death penalty: "He'll live the rest of his life from our taxes." 254 Such testimony has long been presented by prosecutors; what has changed is that the defense now presents a more comprehensive narrative to counter it.

\section{Testimony by the Defendant}

The defendants testified in nine of these sentencing hearings. Jason Andrew James said, "I apologize for what I did."255 William Shanklin testified, "I failed [the victim] for not getting him the proper help like I should have time and again and time after time after time." ${ }^{256}$ Marcus Garrett testified:

\footnotetext{
249. Id. at $71-72$.

250. $I d$. at 74 .

251. Id. at 83 .

252. VA. Code Ann. § 19.2-264.4(A1) (West, Westlaw through end of the 2016 Reg. Sess.) ("In any proceeding conducted pursuant to this section, the court shall permit the victim, as defined in $\S 19.2-$ 11.01 (Westlaw), upon the motion of the attorney for the Commonwealth, and with the consent of the victim, to testify in the presence of the accused regarding the impact of the offense upon the victim."); see also id. $\$ \S 19.2-299.1,16.1-273$ (Westlaw).

253. Victim Impact Statement, Teleguz v. Commonwealth, No. 30946 (Va. Cir. Ct. Rockingham Cty. Jan. 23, 2006).

254. Bill McKelway, Man Sentenced in Deaths of Uncle, Cousin, Richmond Times-Dispatch, (Apr. 24, 2007, 1:08 AM), http://www.richmond.com/news/article_4b5dfead-ddd3-5895-8c58-ed25c493579f. html?mode $=$ print $[$ https://perma.cc/TZD2-MLTX].

255. Id.

256. Shanklin Trial Transcript, supra note 131, at 58 (Feb. 9, 2007).
} 
In June I pled guilty because I am guilty. Never once was I running from this or trying to say that somebody else did this. The only thing that I really said throughout this whole thing is that I don't know exactly what happened. I know now; but as to the why, I still don't know. ${ }^{257}$

All three defendants received life sentences. In the case of Anthony Juniper, the lawyers later complained that "[i]f you have a client that the commonwealth has serious, overwhelming evidence against, it would be easier to defend him if the client accepts responsibility and shows remorse," and "[i]n the absence of an expression of remorse you don't [sic] give a judge or the jury any reason to impose a life sentence." 258 Antwon Whitten, who asserted his innocence, said, "I just want to say that, you know, I am innocent and that's why I'm not showing remorse or trying to ...."259

\section{Virginia Capital Trials from 1996-2004}

This Part turns to twenty trials in the decade before improvements in capital defense in Virginia. The Edward N. Bell case illustrates just how much things have changed.

"Ladies, and gentlemen, he killed an innocent man in cold blood whose wife was pregnant with a child. It wasn't just a man. It was a man wearing a uniform." ${ }^{260}$ In a high-profile case, Edward N. Bell was sentenced to death for the killing of a Winchester, Virginia police officer, shot during a chase. A central issue on appeal and during habeas was the performance of Bell's lawyers at trial. During the 2005 gubernatorial campaign, the wife of the victim said in a TV ad, "How could you not think the death penalty was appropriate?"261 The guilt phase involved some quite circumstantial evidence: an alleged admission to a jailhouse informant, eyewitnesses who briefly caught a glimpse of someone fleeing or near the scene, and how the next day police found Bell hiding in a basement near the crime scene, wearing dark clothes similar to those reported to have been worn by the shooter and with a gun hidden in the leaves outside the home. Having disputed the issue of guilt, Bell's lawyers then presented almost no case at all during sentencing.

257. Garrett Trial Transcript, supra note 229, at 473.

258. Rick Halperin, Death Penalty in Quadruple Killing a First for Both Sides, Virginian-PiLot (Aug. 16, 2005), https://www.mail-archive.com/deathpenalty@ lists.washlaw.edu/msg02738.html [https:// perma.cc/3K7G-JAMP]; see also Theodore Eisenberg et al., But Was He Sorry? The Role of Remorse in Capital Sentencing, 83 CoRNELL L. REv. 1599, 1614-16 (1998) (analyzing the statistical correlation in capital sentencing between a defendant exhibiting remorse and the imposition of a life sentence).

259. Whitten Sentencing Hearing Transcript, supra note 117, at 41.

260. Trial Transcript at 2417-17, Commonwealth v. Bell, No. CR99000478 (Va. Cir. Ct. Winchester, Jan. 26, 2001).

261. Jerry Markon, Jamaican Native Shot Winchester Officer Ricky Timbrook in '99, WASH. PosT (Feb. 20, 2009), http:/www.washingtonpost.com/wp-dyn/content/article/2009/02/19/AR2009021901912. html [https://perma.cc/RN3P-6AAK]. 
In post-conviction hearings examining the effectiveness of the lawyering in the capital defense of Edward Bell, sentenced to death in 2002, the defense lawyer explained that he had learned that "when you fight a capital case to the hilt" at the guilt phase and the jury still decides to convict, then it is "pretty darn insulting to a jury" to then say, "you've convicted him of capital murder, now we want you to forget all of that and show him mercy."262

The federal judge was surprised, saying that it seemed that in cases "that have been tried before me," the defense could say, "We don't agree with that verdict, but ... you have a very important job right now and we want to show you who this person is so that you can better make that decision."263 The judge was troubled that the lawyer was indicating that having fought hard at the guilt phase, "then you kind of give up if the jury finds the defendant guilty." 264 The judge agreed that the Bell case was a difficult one, with a "loved victim, in a relatively small community," but the judge pressed:

But how does that translate into what essentially was a decision ... in which you presented literally no mitigating evidence? There were seven pages of transcript of the defense's case in the sentencing phase. Two witnesses were called. There wasn't a single question asked about Mr. Bell, about his background, about anything about him. ${ }^{265}$

In contrast to the defense's "seven pages of transcript," the prosecutors had called fifteen witnesses, ranging from police officers-who presentted evidence about other crimes, including uncharged violent acts - to family members of the victims, and others. The defense lawyer explained the reasons for not presenting family members or others; Bell had children with different women and was not paying child support, and many of his relatives lived in Jamaica.

But the judge pressed further: "Did you ever consider that it couldn't get any worse?"266 What would be the harm in not presenting "zero mitigating evidence," but doing something to "humanize him" and describe his life, showing that "he had a good relationship with his children"? ${ }^{267}$ The defense lawyer said he "only saw it as a single-edged sword." 268 An experienced death penalty lawyer also testified at the hearing, saying that he had never done so before because he does not "want to second-guess other counsel," but that the performance in the case was substandard. ${ }^{269}$ He noted that it would never "be sensible to not interview" potential witnesses because one is afraid of what they might

262. Evidentiary Hearing Transcript at 24, Bell v. True, Civ. No. 7:04cv00752 (W.D. Va. July 6, 2006).

263. Id. at $24-25$.

264. $I d$. at 25 .

265. $I d$. at $28-29$.

266. Id. at 32 .

267. Id.

268. Id. at 33 .

269. Id. at 4 (July 5, 2006). 
say because "[v]ery often, they lead to other witnesses," and that he had been able to convince witnesses from out of the country to testify in death penalty cases. $^{270}$ The trial lawyers never even requested funding to secure such witnesses.

The federal district court found Bell's lawyers inadequate, but nevertheless ultimately concluded that the Virginia courts were reasonable to rule that those failures did not prejudice the outcome. The Fourth Circuit affirmed, calling this "cross-purpose evidence" which could both serve as aggravation and mitigation. ${ }^{271}$ Bell was executed in 2009, and his final words were: "you definitely have the wrong person. The truth will come out one day." ${ }^{272}$ Thus, the doubleedged sword rationale was used to uphold his conviction despite an almost non-existent mitigation case. It is unfathomable that such a person would be sentenced to death, much less executed, today with current Virginia death penalty lawyers representing him.

\section{A. CHARACTERISTICS OF THE PRE-2005 TRIALS}

The average year in the group of trials was 2000; the trials ranged from 1996 (when life without parole was adopted in Virginia) to $2004 .{ }^{273}$ As with the more recent trials, these were not typically mass murderers; sixteen of the twenty cases involved single victims, whereas the other four involved two murder victims. Four of the twenty cases involved guilty pleas to capital murder (and again, in those cases, the sentencing proceeding was a bench trial). The evidence in these cases was somewhat similar to the more recent trials; twelve of the twenty cases involved forensic evidence (including seven with DNA); twelve involved informant testimony; nine cases involved confessions; and six involved eyewitnesses. This is troubling. In an era of declining death sentences, the evidence of guilt remains mostly unchanged, suggesting the same set of challenges in proving guilt in murder cases may persist.

\section{B. SENTENCING HEARINGS IN PRE-2005 TRIALS}

I examined twenty pre-2005 capital trials in Virginia, and in those cases, the capital sentencing hearings were short, without exception. These cases are displayed in Figure 6, with cases resulting in death sentences marked in black. In the entire group of twenty pre-2005 trials, the average length was less than two days (an average of 1.65 days, and many of the two-day sentencing hearings involved a single day of witness testimony followed by a morning of closing arguments). The entire trials were fairly short. They averaged just under five days long. The guilt phase averaged just under four days, and the guilt

270. Id. at 4,14 .

271. Bell v. Kelly, 260 F. App'x 599, 604-06 (4th Cir. 2008).

272. Markon, supra note 261.

273. I thank the Virginia Capital Resource Center for sharing these materials with me; in some of the cases, the complete trial record was not transcribed for the appendix later prepared for appeal and post-conviction proceedings, but in most cases fairly complete records were available. 
phase was on average twice as long as the quite short sentencing phase. Now, only one of those trials involved a life sentence (which was a less common occurrence at the time). Although it is possible that there is something unusual about the selection of those twenty trials (and far more cases went to trial during that time period), the brief sentencing was striking and consistent. Not only were these sentencing hearings shorter, but the prosecution put on the bulk of the witnesses, averaging eleven witnesses to the five for the defense.

\section{Figure 6: Sentencing Phase (in Days) in 20 Virginia Capital Trials, 1999-2004.}

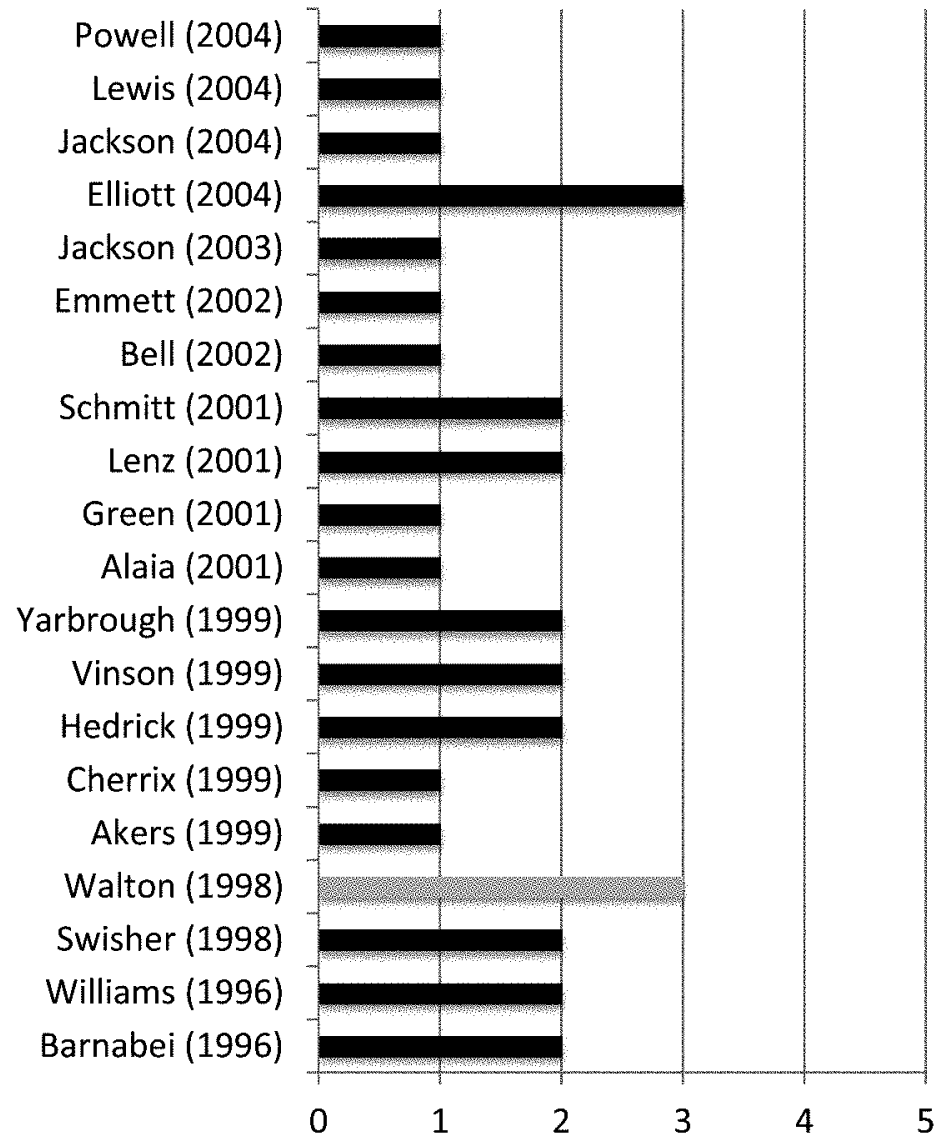

Expressing the minimal importance placed on capital sentencing at the time, in 1997, a judge explained to the jury after it convicted the defendant of capital murder:

Members of the jury, we-we now have one more hearing. And-and we'll now-the lawyers are ready to go with that. And, at the conclusion of this 
hearing, when all the evidence is in-and it won't be a long hearing; not certainly like anything what you've been through to get to this point . . . ${ }^{274}$

A two-day sentencing hearing followed. Evidently, the expectation was that sentencing even in a death penalty case in the late 1990s was an afterthought to the main event - the guilt phase. Why were sentencing hearings so short during that time?

The inadequacy of defense lawyering, and the reluctance of judges to provide resources to the defense, may help to explain the cursory sentencing work in other pre-2005 trials. In the case of Brandon Wayne Hedrick, which featured a brief two-day sentencing hearing, one of his lawyers later said that he was "unaware" of what his co-counsel was doing to prepare for the case, and thought that his partner would be handing the entire sentencing phase; as a result he "did not prepare for that part of the case," and he "got the impression the case was going to plead out," so was "disappointed" to learn days before trial that a trial would occur. He added, "Although I believe in the death penalty, I do not think that Brandon Hedrick deserved the death penalty." 275 Later Hedrick's lawyers would argue that he was intellectually disabled, and that the IQ of seventy-six found by the state's psychologist at trial might not be accurate, requiring a new mental health evaluation. There was no re-evaluation, and he was executed in $2006 .^{276}$ The judge denied habeas relief.

In the case of Teresa Lewis, the prosecutor argued that "there's been a lot made of her having a low I.Q. Low I.Q. does not translate into absence of the ability to scheme and think and plan." ${ }^{277}$ The defense, however, did not present any mental health expert (instead presenting only two witnesses, a probation officer and a family friend), and did not even mention mental health in their closings. The judge, when deciding to sentence Lewis to death, emphasized that it was a "cold blooded, pityless slaying," and never even mentioned the presence of any mitigation evidence. ${ }^{278}$ Later, her habeas petition alleged, among other things, failure to investigate mitigating evidence, including evidence of mental retardation. In federal court, there was a battle of the experts, with a state psychologist finding no evidence of mental retardation, and Lewis' experts discussing her medical problems over many years, evidence of a "dependent personality," evidence of retardation, and effects of addiction on her behavior. ${ }^{279}$ Once again, the federal district court and the Fourth Circuit denied

274. Swisher Trial Transcript, supra note 237, at 62.

275. Affidavit of Lee R. Harrison, Esq. at 2, Hedrick v. Braxton (Va. Cir. Ct. for Appomattox Cty. May 30, 2000).

276. Jack Payden-Travers, VA Should Focus on Crime Prevention, Not Death Penalty, FreE LANCE STAR (Aug. 8, 2006), http://wrongfulconvictions.blogspot.com/2006_08_06_archive.html [https://perma. $\mathrm{cc} / \mathrm{K} 3 \mathrm{AH}-\mathrm{BA53}$ ].

277. Trial Transcript at 250, Commonwealth v. Lewis, No. 032153 (Va. Cir. Ct. Pittsylvania Cty. June 3, 2003).

278. Id. at 283.

279. Lewis v. Wheeler, No. 7:07CV00538, 2009 WL 588957, at*14 (W.D. Va. Mar. 6, 2009). 
relief, finding that under the deferential AEDPA standards, the lawyer pursued a reasonable trial strategy, and that intellectual disability evidence might be "double edged" since it might also tend to show future dangerousness. ${ }^{280}$ Following unsuccessful clemency efforts raising her mental capacity, Lewis was executed in $2010^{281}$

In the case of Enrico J. Alaia, there was a short one-day sentencing hearing where the defense presented only one witness, the defendant's mother, and offered a closing argument of only a few pages, mostly noting that their decision would have an effect "upon another family . . . through no fault of their own." 282 Aside from the mother, the jury had not heard from that family. Even still, the jury wavered before imposing the death penalty and asked: "When you say imprisonment for life, is there a chance for parole?" The judge agreed parole had been abolished for capital murder, but the judge responded, "I refuse to" give that instruction (and the case was later reversed for that reason). ${ }^{283}$

To be sure, trial courts may have also changed in their approach towards requests for experts from the defense. The case of Derek Barnabei revolved around forensic evidence, and the defense made requests to obtain their own forensic experts and to test a large amount of forensic evidence that the State had not tested; the judge denied those requests. ${ }^{284}$ The federal courts later found the failures of the trial lawyer to develop the forensic evidence "not unreasonable" and noted that there was "no indication" that had the lawyer asked the court for more money for expert services, the motion would have been granted. Moreover, without knowing what any additional DNA tests would have shown, there was no way to know whether more forensics would undermine "the Court's confidence in the outcome of the proceedings."285

The trial lawyers had a more difficult ethical and practical question in the case of Thomas Wayne Akers, who pleaded guilty to capital murder and then outright refused to allow his lawyers to present any mitigation evidence at all at sentencing. The sentencing hearing was just a day long. Akers' lawyers asked for an ethical opinion on whether they should honor their client's request, and the Virginia State Bar emphasized the importance of carefully counseling the client on this issue. Akers persisted, and one of his lawyers explained to the judge, "This is what he wants to do. It is against our advice, but we are required

280. Lewis v. Wheeler, 609 F.3d 291, 302 \& n.4 (4th Cir. 2010).

281. Maria Glod, Virginia Executes Teresa Lewis for Role in Slayings of Husband, Stepson in 2002, WASH. Post (Sept. 23, 2010, 11:36 PM), http://www.washingtonpost.com/wp-dyn/content/article/2010/ 09/23/AR2010092306827.html [https://perma.cc/95XR-89BK].

282. Trial Transcript at 1293, Commonwealth v. Alaia, No. CR98F00530 (Va. Cir. Ct. Chesterfield Cty. Dec. 10, 1998).

283. Id. at 1301-02; Alan Cooper, Killer Dies in Prison Awaiting Appeal Ruling, Richmond Times-Dispatch, Jan. 5, 2002, at B-3.

284. Corrected Brief of Appellant, Barnabei v. Commonwealth, No. 952168 at 6, 11 (April 22, 1996) (Joint Appendix Vol. 3)).

285. Memorandum Op. at 34-35, Barnabei v. Angelone, No. 3:98CV82 (E.D. Va. July 26, 1999). 
to follow his directions." 286

At sentencing, the prosecutor emphasized that Akers "enjoyed killing his victim," and had said, "If I am left alive, I promise you that I will kill again within the system or after I escape from the system."287 The prosecutor emphasized, "I think with Mr. Akers what you see is what you get." ${ }^{288}$ The trial lawyer obtained a mental health opinion on the question whether Akers was competent to waive such rights, and the expert concluded, "It makes all parties uncomfortable to see a defendant choose to place himself in the worst legal position possible" by waiving his right to present evidence in mitigation, but there was "no viable reason to question [Akers'] competency to do so."289 And as sentencing concluded, the judge asked Akers if he wanted to comment. Akers said, "I have no sympathy or remorse for what I did, and I plan to commit another capital murder in the future." 290 When his lawyers asked their client if they could appeal, he told them, "I am a future danger to a lot of people if I am left alive and won't hesitate to take another life," instructing them not to appeal. ${ }^{291}$ The Virginia Supreme Court took the appeal anyway, obligated to do so by statute, and denied it; Akers was executed the next year. ${ }^{292}$

Similarly, in the case of Marlon Williams, the defendant pleaded guilty to capital murder, and the sentencing hearing was little more than a day long. The defendant presented the defendant's probation officer and his aunt, who had raised him for ten years and who described the childhood abuse he suffered from his mother and stepfather. The defense submitted dated psychological reports from 1986 and 1989, but nothing more recent. The defense otherwise emphasized that Williams had pleaded guilty to accept responsibility, telling the judge: "If you need the mitigation, I think I've given you the mitigation."293 The prosecutor responded, "Yeah, he accepted responsibility by making a guilty plea only after" the person who hired him was convicted; “[h]e doesn't deserve any credit for that." ${ }^{294}$ Williams was sentenced to death. The judge even noted, "I have a case in which I have a lot of papers dealing with psychological background and so forth but I really don't have any expert testimony to help me with that. It's just a comment." 295 The judge added, "I would say that I don't hold that against the defense whatsoever that there is no expert testimony. I

286. Sentencing Hearing Transcript at 40, Commonwealth v. Akers, No. CR 99-05-7922 (Va. Cir. Ct. Franklin Cty. Nov. 5, 1999) [hereinafter Akers Sentencing Transcript].

287. $I d$. at 48.

288. Id. at 47 .

289. Notice at 1, Akers v. Commonwealth, No. 992894 (Va. Jan. 14, 2000).

290. Akers Sentencing Transcript, supra note 286, at 50.

291. Hearing Transcript at 20, Akers v. Commonwealth, No. CR99-5-7922 (Va. Cir. Ct. Franklin Cty. Mar. 16, 2000).

292. Akers v. Commonwealth, 535 S.E.2d 674, 678 (Va. 2000); Frank Green, Appeals Rejected, Akers Executed, Richmond Times-Dispatch, Mar. 2, 2001, at B 1.

293. Trial Transcript at 39, Commonwealth v. Williams, No. 95-330 (Va. Cir. Ct. City of Chesapeake Oct. 11, 1995).

294. Id. at $41-42$

295. Id. at 64 . 
don't think he was required to do it."296 The Virginia Supreme Court found the death penalty appropriate, while noting that "the evidence of Williams' psychological background was insufficient to mitigate his offense ...."297 Yet little evidence about his psychological background had been presented, and it could have made the difference between a life and death sentence.

In yet another case from the heyday of the Virginia death penalty, Percy Levar Walton, who received a commutation in 2008, had been earlier sentenced to death despite experts agreeing that he was intellectually disabled and schizophrenic. He had pleaded guilty to capital murder in 1997, and had told a state-appointed psychiatrist that "he would be able to come back to life shortly after his execution with the same name but a new spirit."298 At trial, his attorneys had presented no experts; they decided somehow that it "would not have been helpful," which the Fourth Circuit characteristically found to have been a "more than reasonable" choice of strategy. ${ }^{299}$ The issue was considered only years later during habeas proceedings. ${ }^{300}$ Walton apparently thought his execution might bring his victims back to life, as well as his grandfather, and that he might then get a trip "to Burger King on a motorcycle." ${ }^{301}$ Given the outcomes in more recent capital trials in Virginia, it is hard to imagine that someone like Walton would be sentenced to death today had the lawyers introduced the battery of expert testimony that they put on during the federal habeas proceedings.

\section{The Virginia and the American Death Penalty Decline}

This Part concludes by examining the implications of this case study for the future of the American death penalty. I begin by examining other possible contributors to the death penalty decline in Virginia, including public opinion, cost, geography, and crime rates. Second, I compare the Virginia decline to the quite similar decline experienced in North Carolina, which established statewide public defenders, and contrast the Virginia decline to the persistence of death sentencing in Florida, which has not established statewide capital defenders. These patterns suggest that capital representation may be a significant factor in the death penalty decline, a subject that should be examined in further

296. $I d$.

297. Williams v. Commonwealth, 472 S.E.2d 50, 54 (Va. 1996).

298. Walton v. Johnson, 440 F.3d 160, 163 (4th Cir. 2006).

299. $I d$.

300. Id. at 164-66. The Fourth Circuit's reasoning regarding the Atkins claim, that "because Walton failed to allege sufficient facts demonstrating that his intellectual functioning was 70 or less before he turned 18, the district court properly dismissed Walton's mental retardation claim," see id. at 178, would not be permitted today under the Supreme Court's ruling in Hall v. Florida, 134 S. Ct. 1986 (2014).

301. Candace Rondeaux, Inmate's Execution Still Set for Tonight, WASH. Post (June 8, 2006), http://www.washingtonpost.com/wp-dyn/content/article/2006/06/07/AR2006060702201_pf.html [https:// perma.cc/X7MRREDS]. 
empirical work, and which may influence policy for regulating the death penalty as well as constitutional arguments concerning the American death penalty.

\section{A. PUBLIC OPINION, COST, GEOGRAPHY, AND CRIME RATES}

Perhaps other explanations, such as changing judicial opinion, public opinion, or cost, or local decisionmaking, or crime rates, might also explain the decline in death sentencing in Virginia, and not just improved defense resources. This section explores those possibilities.

Although sentencing phase proceedings have become more complex in Virginia in the past decade, it could be that judges have also become more open to the importance of sentencing in capital cases. Perhaps judges have themselves increasingly understood the importance of a robust capital trial. That could be the result of Supreme Court opinions, or reversals on appeal and postconviction, for one. The federal courts may have become more open to reviewing Virginia death sentences on habeas review. More cases may be reversed for prosecutorial misconduct, ineffective assistance of defense lawyers, or even claims of innocence, as the composition of the federal bench has changed. ${ }^{302}$ Recent Supreme Court rulings regarding mental illness and intellectual disability may have improved evaluation of capital defendants and resulted, in Virginia as in other states, in stricter standards for evidence on that subject. ${ }^{303}$ Those rulings may be relied on by defense lawyers requesting resources for experts, investigators, or to bring in additional witnesses at sentencing. Those rulings may have gradually improved standards in the defense bar.

Public opinion regarding the death penalty has declined nationwide. ${ }^{304}$ As the politics of the death penalty have shifted, perhaps this has affected judges and prosecutors, also making it more palatable to settle capital murder cases without seeking the death penalty and more feasible to present a complete mitigation case when the death penalty is sought.

Today, Virginia's longtime (now retired) executioner opposes the death penalty. ${ }^{305}$ By the time death sentencing began to decline in Virginia, the issue had begun to figure less prominently in state politics. For example, Governor Tim Kaine was elected despite his opponent's attacks on his stated religious opposi-

302. There have been several such cases in recent years in Virginia. See Associated Press, Fewer Killers Get Death Penalty, supra note 42.

303. Atkins v. Virginia, 536 U.S. 304, 321 (2002); see, e.g., VA. CodE AnN. § 19.2-264.3:1.1(C), (D) (West, Westlaw through end of the 2016 Reg. Sess.).

304. Baxter Oliphant, Support for Death Penalty Lowest in More than Four Decades, Pew Res. CTR. (Sept. 29, 2016), http://www.pewresearch.org/fact-tank/2016/09/29/support-for-death-penalty-lowest-inmore-than-four-decades/ [https://perma.cc/U78D-MCMY].

305. Justin Jouvenal, Ex-Virginia Executioner Becomes Opponent of Death Penalty, WASH. Post (Feb. 10, 2013), https://www.washingtonpost.com/local/ex-virginia-executioner-becomes-opponent-ofdeath-penalty/2013/02/10/9e741124-5e89-11e2-9940-6fc488f3fecd_story.html [https://perma.cc/8296REWG] ("If I execute an innocent person, I'm no better than the people on death row . ..."). 
tion to the death penalty. ${ }^{306}$ As Governor, Kaine vetoed legislation that would have expanded the death penalty, citing his personal moral opposition to the death penalty and stating, "I don't think we need to expand capital punishment in Virginia to protect human life and keep people safe . . ."307 More recently, legislation to keep execution protocols secret and exempt from open-records laws failed in the legislature. ${ }^{308}$ Those changing politics may have also affected potential jurors, and therefore the decisions of prosecutors in charging cases. Richard Dieter of the Death Penalty Information Center said in 2014, "Potential jurors who sit on these cases all come from a changing Virginia.... The jurors are more skeptical, which is representative of a changing America as well."309 Changing politics may have also affected victims, who may tell prosecutors more often than in the past that they do not support seeking the death penalty.

It is possible that longstanding concerns about race discrimination in the administration of the death penalty may have played a role in the changing pattern of the past decade, but that is doubtful; nothing specifically has been done in Virginia (or in many other states for that matter) to address that concern. ${ }^{310}$ Cost considerations certainly played a role in the creation of the RCD offices, as described; it is also possible that cost considerations have affected capital charging in Virginia. Longer and more complex sentencing hearings certainly are more costly for the prosecution, and not just the defense. Data from the Virginia Indigent Defense Commission on the defense costs in capital murder cases indicate that cases involving capital murder charges can result in tens or even hundreds of thousands of dollars of defense costs where the result is a guilty plea. However, capital cases that go to trial can result in far more; the Joshua Andrews trial in 2007 resulted in a death sentence and almost $\$ 750,000$ in defense costs; the Alfredo Prieto case resulted in over $\$ 1.4$ million in defense costs before the lengthy resentencing proceedings conducted in

306. Michael D. Shear, References to Hitler in Kilgore Ad Criticized, WASH. Post (Oct. 15, 2005), http://www.washingtonpost.com/wp-dyn/content/article/2005/10/14/AR2005101402037.html [https:// perma.cc/C4KN-8SMT].

307. Sandhya Somoashekhar, Kaine Vetoes Death Penalty Expansion, WASH. Post (Mar. 27, 2007), http://www.washingtonpost.com/wp-dyn/content/article/2007/03/26/AR2007032601731.html [https:// perma.cc/ETR8-98DU].

308. Jenna Portnoy, Va. House Kills Lethal Injection Secrecy Bill Despite Support of McAuliffe, WASH. Post (Feb. 24, 2015), https://www.washingtonpost.com/local/virginia-politics/va-house-kills-lethalinjection-secrecy-bill-despite-support-of-mcauliffe/2015/02/24/83bc656a-bc4d-11e4-8668-4e7ba8439ca 6_story.html [https://perma.cc/2J5K-Q5HW].

309. Speed \& Dujardin, supra note 114.

310. Only two states enacted Racial Justice Acts to study race and death sentencing, Kentucky and North Carolina, with North Carolina repealing its Act, and New Jersey additionally conducting such an inquiry by court order. Ky. Rev. Stat. AnN $\$$ 532.300(1) (West, Westlaw through end of the 2016 Reg. Sess.); N.C. Gen. Stat. Ann. §§ 15A-2010-15A-2012 (West, Westlaw through S.L. $2009-577$ (end) of the 2009 Reg. Sess.); see also Alex Lesman, State Responses to the Specter of Racial Discrimination in Capital Proceedings: The Kentucky Racial Justice Act and the New Jersey Supreme Court's Proportionality Review Project, 13 J. L. \& PoL'y 359, 384 (2005). 
$2010 .{ }^{311}$ The amounts vary quite a bit; in contrast, the Xenia Morgan case, which resulted in a life sentence after a guilty plea to capital murder, involved a short sentencing hearing and about $\$ 105,000$ in defense costs; the Berman Justus case which also resulted in a life sentence also involved about $\$ 125,000$ in defense billing. ${ }^{312}$ If more often than not, capital proceedings result in a life sentence regardless, then the cost of mounting a capital prosecution may figure significantly in the charging calculus.

Geography supplements this story. Larger counties may be better able to shoulder the expense of capital trials, both on the prosecution side and the defense side, in states in which indigent defense is chiefly funded locally. Perhaps reflecting these changing political and cost considerations, more of the capital trials occurred in the largest Virginia counties. Three of the trials since 2005 occurred in Fairfax County, which with a population of over one million, is the largest county in Virginia. Two of the trials occurred in the largest city in Virginia, Virginia Beach, which has over 400,000 people. ${ }^{313}$ The vast majority of the trials (seventeen of twenty-one) occurred in the fifteen largest counties and the ten largest cities in Virginia. ${ }^{314}$ Virginia has ninety-five counties (and forty-one independent cities incorporated from a county), and many of the other large jurisdictions in Virginia, like Arlington, Chesterfield, and Loudoun counties, have not seen a capital trial in the past decade. Few jurisdictions in Virginia currently impose the death penalty.

Death sentences are even more localized than capital trials because, after all, most capital trials now result in life sentences. In the last decade, only seven jurisdictions imposed death sentences in Virginia, and nine of the eleven death sentences were imposed in the largest jurisdictions. ${ }^{315}$ Since the 1970s, Fairfax County, Prince William County, and Virginia Beach have been responsible for the most executions in Virginia, but in the 1980s and the 1990s, smaller counties, like Pittsylvania and Portsmouth City also produced sizable numbers of death sentences. ${ }^{316}$ Death sentences, for example, from 1977 until 2004, were

311. Capital Murder Defendants, FY 2004 to Date, supra note 97.

312. Id.

313. U.S. Census Bureau, Annual Estimates of the Resident Population, April 1, 2010 to July 1, 2012, http://factfinder.census.gov/faces/tableservices/jsf/pages/productview.xhtml?pid=PEP_2012_ PEPANNRES\&prodType $=$ table $[$ https://perma.cc/WSU7-JERX].

314. Those counties are: Fairfax County (3), Henrico County (2), Montgomery County (1), Newport News (2), Norfolk (2), Prince William County (1), Rockingham County (1), Stafford County (2), and Virginia Beach (3). The few additional trials occurring in smaller jurisdictions were in Amherst (1), Green (1), Halifax (1), and Roanoke (1). See Appendix A.

315. Since 2004, death sentences have been imposed in only seven jurisdictions in Virginia: Fairfax (3) (including Prieto's resentencing), Norfolk (2), Amherst (1), Montgomery (1), Prince William (1), Richmond (1), and Rockingham (1). See generally Richard C. Dieter, Death Penalty Info. Ctr., The 2\% Death Penalty: How a Minority of Counties Produce Most Death Cases at Enormous Costs to ALL (2013).

316. A spreadsheet showing Virginia capital litigation by county can be viewed at the Capital Litigation Data, Va. Capital Case Clearinghouse: A Legal Clinic at Washington \& Lee Univ. Sch. of 
produced in large numbers in Arlington County (eight), Chesterfield County (twelve), and Richmond (thirteen), as well as smaller jurisdictions like Danville (eight), which have produced no death sentences in the past decade. ${ }^{317}$ As Professor James Liebman has documented, "A given defendant's likelihood of receiving a sentence of death depends greatly on the county in which he was tried." 318 This is all the more true today in Virginia. The three maps below show just how much has changed.

\section{Figure 7: Virginia Death Sentences by County, 1987-1995.}

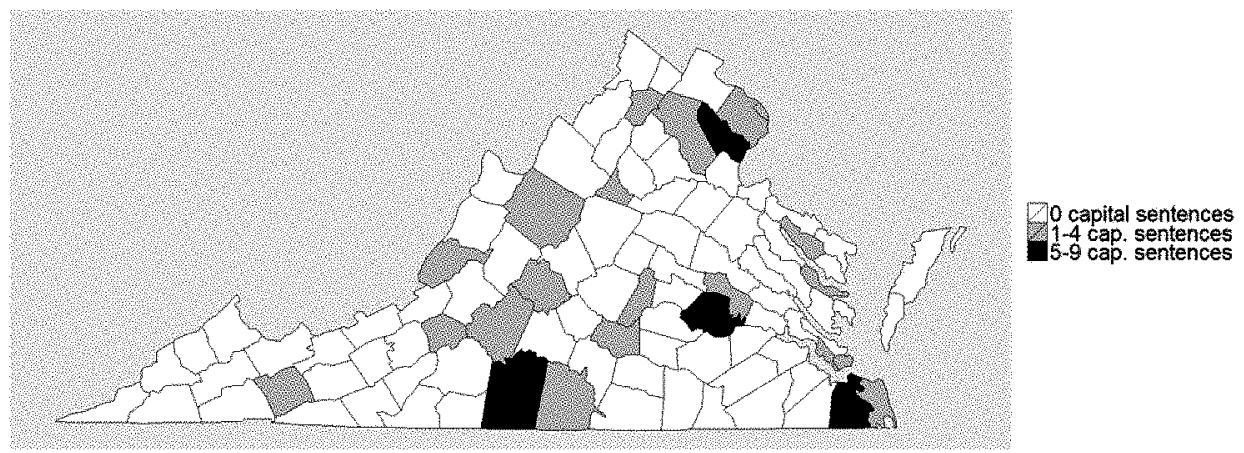

Figure 8: Virginia Death Sentences by County, 1996-2004.

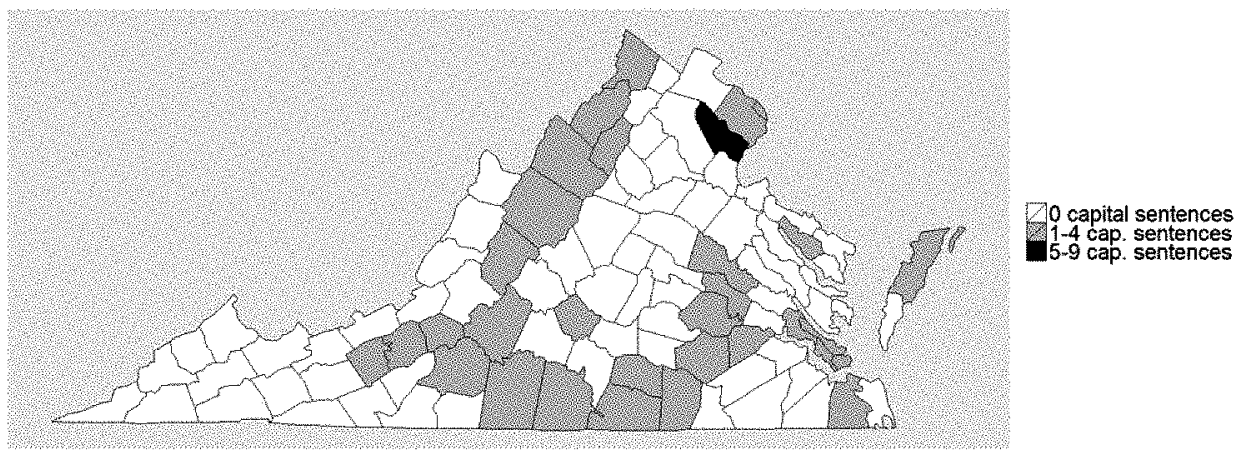

LAW, http://Www.vc3.org/resources/page.asp?pageid=561 [https://perma.cc/6BEJ-D99P] (last visited Nov. 1, 2016).

317. Indeed, from 1977 until 2004, Fairfax imposed just five death sentences, compared with smaller jurisdictions which imposed many more (Prince William imposed thirteen, Richmond imposed thirteen, Chesterfield imposed twelve, Virginia Beach imposed eight, etc.). See id.

318. James S. Liebman \& Peter Clarke, Minority Practice, Majority's Burden: The Death Penalty Today, 9 Оніо Sт. J. CRIM. L. 255, 265 (2011) (finding between 1973 and 1995, counties where only $20 \%$ of Americans live imposed $43 \%$ of death sentences and $70 \%$ of executions; in just death penalty states, counties with $10 \%$ of population imposed $38 \%$ of death sentences). 
Figure 9: Virginia Death Sentences by County, 2005-2014.

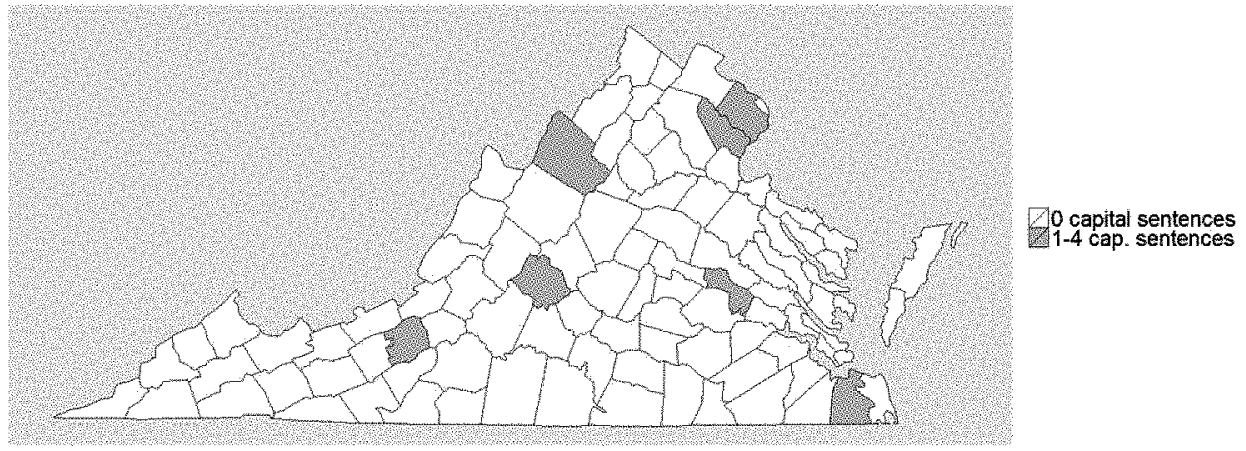

Increasing geographic concentration suggests that broader state or national trends in murder rates do not completely explain what is happening. Take a second trend that predates declining public support for the death penalty: the broad decline in homicide rates in the 1990s, which preceded the decline in death sentences in the United States. Homicide rates in the United States began a decline in the early 1990s, as did crime generally, for crimes as varied as aggravated assault, rape, robbery, burglary, and auto theft. ${ }^{319}$ None of the leading criminologists or criminal justice planners expected this remarkable decline, as Professor Frank Zimring has described. On the heels of what Professor Zimring has called the Great American Crime Decline, ${ }^{320}$ a remarkable national decline in death sentences would follow. Yet the death penalty decline occurred a decade later, and in some counties far more than others - and with other problems with the causal story, including that the decline in the murders that are eligible for the death penalty may have been far more slight. ${ }^{321}$

Scholars have increasingly examined the mounting geographical concentration of the death penalty in a small number of outlier counties. ${ }^{322}$ Additional empirical work in progress further calls into question any relationship between county-level murders and death sentencing, and instead suggests that statewide capital defense, together with local prosecution practices as well as population density and racial demographics, explain which counties still impose death sentences. ${ }^{323}$

319. Franklin E. Zimring, The Great American Crime Decline 6-7 (2007).

320. Id. at 21.

321. Jeffrey Fagan, Franklin E. Zimring \& Amanda Geller, Capital Punishment and Capital Murder: Market Share and the Deterrent Effects of the Death Penalty, 84 TEx. L. REv. 1803, 1824-26 (2006).

322. See Dieter, supra note 315; Lee Kovarsky, Muscle Memory and the Local Concentration of Capital Punishment, 66 Duke L.J. 259 (2016); James S. Liebman \& Peter Clarke, Minority Practice, Majority's Burden: The Death Penalty Today, 9 Оно Sт. J. Criм. L. 255 (2011); Robert J. Smith, The Geography of the Death Penalty and Its Ramifications, 92 B.U. L. REv. 227, 265-75 (2012).

323. See Garrett, Jakubow \& Desai, supra note 4. This work in progress conducts detailed statistical analysis of comprehensive data collected on county-level death sentencing for the modern era of capital punishment. 


\section{B. THE DECLINING DEATH PENALTY IN NORTH CAROLINA}

Although North Carolina was once one of the leading death penalty states, today North Carolina looks more like neighboring Virginia. Starting in 2000, death sentences began a precipitous decline in North Carolina, although not as great as that in Virginia. In North Carolina, executions were halted for years due to litigation regarding execution protocols and the enactment of the 2009 Racial Justice Act. ${ }^{324}$ The general trend is very similar, though. Life was always imposed more than death at capital trials in North Carolina, but both sharply declined to the point where there are now only a handful of death sentences each year, and in both 2012 and 2015 there were none. What changed in North Carolina?

Figure 10: Capital Trials in North Carolina, 1994-2014. Sources: North Carolina Center for Death Penalty Litigation and Office of Capital Defender.

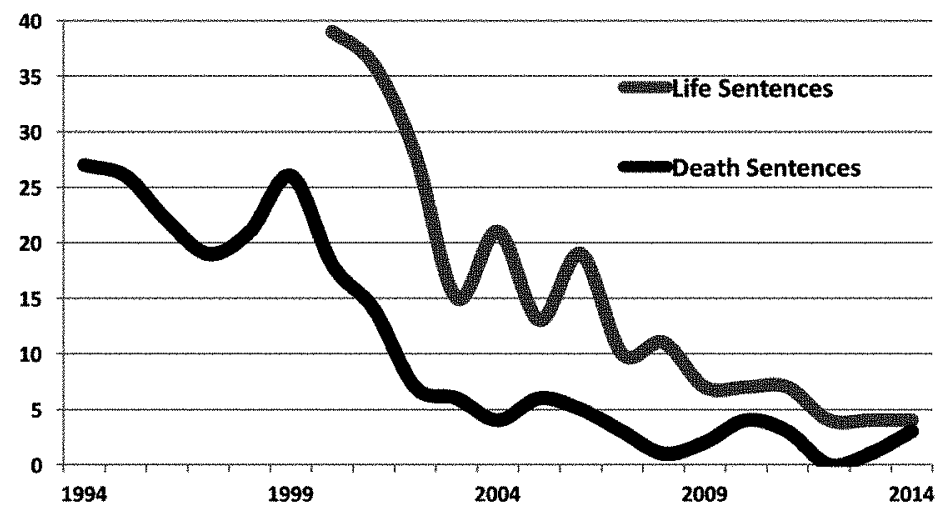

The changes in North Carolina look much like the changes in Virginia that occurred at around the same time. In 2001, similar to what happened in Virginia in the following year, a statewide North Carolina Office of the Capital Defender was created, following several years of study by a legislative commission and the adoption of a law called the Indigent Defense Services Act of $2000 .{ }^{325}$ The law did not create regional offices that actually handled death penalty trials, like

324. See N.C. Dep't of Pub. Saftey, Offenders on Death Row, https:/www.ncdps.gov/Index2. cfm?a =000003,002240,002327,002328 [https://perma.cc/3BHA-CT3R] (last visited Oct. 14, 2015); Sharon McCloskey, North Carolina Adopts a New Death Penalty Protocol, NC Policy WaTCH (Nov. 5 , 2013, 11:54 AM), http://www.ncpolicywatch.com/2013/11/05/north-carolina-adopts-a-new-death-penaltyprotocol/ [https://perma.cc/H5SY-7KRU].

325. N.C. Gen. Stat. §7A-498.2 (West, Westlaw through Chapter 93, 95 to 99 and 101 of the 2016 Reg. Sess.); see Indigent Defense Study Commission, Report and Recommendations 1 (2000), http://www. ncids.org/home/ids\%20study\%20commission\%20report.pdf [https://perma.cc/V5BP-DCYB] (finding that "[i]ndigent defense in this state suffers, as to both cost-effectiveness and quality of representation, from lack of any centralized authority to provide coordinated planning, oversight, or management"). 
in Virginia. Instead, there was a qualification process, and an approved roster of death penalty lawyers. ${ }^{326}$ Appointments were to be made more carefully in such cases, with statewide standards for performance. And unlike in Virginia, trial judges cannot appoint lawyers in death penalty cases. Instead, the Office of the Capital Defender decides which lawyers represent a defendant in a death penalty case, and appoints one "as soon as feasible" after capital murder is charged. ${ }^{327}$ A defendant has an expert lawyer at the very first hearing in front of a judge, and a second lawyer is appointed after that hearing.

Other changes took hold in North Carolina at about the same time. In 2002, the law was changed to give prosecutors the discretion to decline to bring a case as a death penalty case, even if it was potentially death-eligible. Previously, district attorneys were required to proceed as if it was a death penalty case. A new statute prohibited the capital prosecution or the execution of the intellectually disabled. ${ }^{328}$ And, the halt in executions due to lethal injection challenges, together with the Racial Justice Act's passage in 2009 (although it was repealed in 2013) may have affected decisions to charge cases capitally. ${ }^{329}$ Data collection under that Act may have delayed and discouraged death penalty cases. Challenges to lethal injection protocols resulted in new statutory protocols in North Carolina and may have had some effect, at least prior to the Supreme Court's decision in Baze v. Rees. ${ }^{330}$

During this time, there were also four death row exonerations. Lawyers at the Office of the Capital Defender note that when interviewing mock jurors they began to hear more and more concerns about wrongful convictions. During this time, the North Carolina Innocence Inquiry Commission was created, and legislation was enacted to require recording of interrogations and improved lineup procedures as well as the creation of an Actual Innocence Inquiry Commission to examine potential wrongful convictions. ${ }^{331}$

Nevertheless, the decline in North Carolina death sentences was already underway when these changes were made. These changes may have hastened a trend that was itself partially the result of the declining homicide rates nationally. As in Virginia, there are many overlapping explanations for the decline. Public opinion may have also played a role. Unlike in Virginia, in North Carolina, there was heightened public debate and legislation concerning the death penalty, including due to enactment of the Racial Justice Act.

326. Office of Indigent Defense Servs., Rules for Providing Legal Representation in Capital CASEs, Part 2, Part 2A (2015).

327. N.C. Gen. Stat. §7A-451(b) (West, Westlaw through end of the 2016 Reg. Sess.).

328. Id. $§ 15 \mathrm{~A}-2005$ (Westlaw).

329. Matt Smith, 'Racial Justice Act' Repealed in North Carolina, CNN (June 21, 2013, 3:48 AM), http://www.cnn.com/2013/06/20/justice/north-carolina-death-penalty/ [https://perma.cc/BR2E-7M2E].

330. 553 U.S. 35 (2008); see N.C. GEN. STAT. § 15-188 (West, Westlaw through end of the 2016 Reg. Sess.).

331. N.C. InNocence Inquiry Comm'n, http://www.innocencecommission-nc.gov/ [https://perma.cc/ E6B7-MP4F] (last visited Nov. 27, 2016); see also GARRETT, supra note 58, at 242-43. 
A preliminary examination of North Carolina capital trials is suggestive at least of how the litigation has changed during that time period. I have examined eighteen death penalty trials, eight of which occurred from 1995 to 1999 , and ten of which occurred in more recent years, from 2004 through 2011. All of these trials involved death sentences, so this collection-obtained from the North Carolina Office of the Capital Defender-did not include cases where a life sentence was obtained, which might display weaker prosecution cases, and conversely, stronger defense cases. There was less egregiously poor sentencing representation in North Carolina; the average in the pre-2000 cases was a four-day sentencing hearing, and in the recent cases the average was a five-day sentencing hearing. In general, the sentencing phase averaged four days and the guilt phase averaged eight days. Unlike in Virginia, however, the practice in North Carolina has apparently sometimes been to introduce mitigation evidence during the guilt phase, making a rigid comparison between the two phases less useful for North Carolina capital trials. However, the general pattern fits: in North Carolina, as in Virginia, with improved capital defense, death sentencing dramatically declined.

\section{THE FLORIDA COUNTEREXAMPLE}

Florida also experienced a decline in the death penalty around the same time as Virginia and North Carolina. Once again, in states with different conditions, one sees a drop in death sentences beginning around 2000. The decline in Florida, however, is not as steep as in states like Virginia and North Carolina. And unlike Virginia and North Carolina, in Florida, capital sentences started to rebound in the past few years, but it seems that they have now begun to decline yet again. Florida has almost 400 individuals on its death row. ${ }^{332}$ Death sentences declined to fewer than ten a year by 2004, and then began to increase again to over ten or so a year over the past few years (there were fourteen in 2011, seventeen in 2012, fourteen in 2013, twelve in 2014 and ten death sentences in 2015). ${ }^{333}$

The comparatively mild decline in Florida may be due to the decline in murders in Florida and nationwide, but not any dramatic change in the legal rules or in the available resources for capital defense lawyers. There are twenty regional public defenders in Florida, and there was a Capital Cases Commission that maintained a registry of attorneys qualified for capital cases, but it was repealed in 2011, and as a result, there currently is no such registry; ${ }^{334}$ in addition, Florida caps pay for trial counsel appointed by the court at $\$ 3,500$,

332. Death Row Roster, Fla. DeP't oF CORRections, http:/www.dc.state.fl.us/activeinmates/ deathrowroster.asp [http://perma.cc/4SG9-FNDC] (last visited Nov. 1, 2016).

333. $I d$.

334. Fla. Stat. Ann. $\S \S 27.709$ (1)(a), (2)(a) (2011), repealed by Act of July 1, 2011, Ch. 131, § 1, 2011 Fla. Laws No. 5011 (West, Westlaw through 2016 Second Reg. Sess.); In re Amendment to Florida Rules of Judicial Administration - Minimum Standards for Appointed Counsel in Capital Cases, 711 So.2d 1148, 1149-50 (Fla. 1998); FLA. R. Crim. P. 3.112(f). 
with additional funding available for experts or investigators. ${ }^{335}$ And although the public defender must provide two lawyers for a capital trial, the statutes note only that a judge "should" appoint a co-counsel in a death penalty case, but leaves it to the discretion of a trial judge. ${ }^{336}$ A Florida law specifically bars a public defender from withdrawing from a case "based solely upon inadequacy of funding or excess workload." ${ }^{337}$ The public defenders do have resources for hiring experts and investigators. ${ }^{338}$ Defendants raising intellectual disability as an issue may request a mental health expert, but that expert is appointed by the court and is selected by the State. ${ }^{339}$ The 2013 "Timely Justice Act" has further expedited death penalty cases (much like earlier legislation aimed to do in Virginia). ${ }^{340}$ Nor are there statewide post-conviction groups litigating death penalty cases in Florida.

It is too early to tell whether the recent resurgence in capital sentences in Florida is an aberration or a temporary reversal of the decade-long trend of a declining death penalty. If it is no aberration, Florida will soon become the lead death penalty state in the United States, after California, which has not executed anyone since 2006 , but where voters recently passed a ballot initiative designed to hasten executions, which has been stayed for review by the California Supreme Court. ${ }^{341}$ Then again, perhaps capital sentences in Florida will soon

335. Fla. Stat. Ann. \& 27.5304(3)-(5) (West, Westlaw through 2016 Second Reg. Sess.). But see White v. Bd. of Cty. Comm'rs of Pinellas Cty., 537 So.2d 1376, 1380 (Fla. 1989); Makemson v. Martin Cty., 491 So. 2d 1109, 1115 (Fla. 1986) (permitting added compensation in "extraordinary and unusual cases").

336. Fla. R. Crim. P. 3.112(e).

337. Fla. Stat. Ann. $\$ 27.5303(1)(d)$ (West, Westlaw through 2016 Second Reg. Sess.).

338. Fla. Stat. Ann. \$29.006(3)-(4) (West, Westlaw through 2016 Second Reg. Sess.). Courtappointed attorneys are entitled to funding for "reasonable" expenses. Id. $\$ 29.007$ (Westlaw); see American Bar Ass'n, Evaluating Fairness and Accuracy in State Death Penalty Systems: The Florida Death Penalty Assessment Report, An Analysis of Flordda's Death Penalty Laws, ProceDURES, AND PRACTICES 152-60 (2006) http://www.americanbar.org/content/dam/aba/migrated/moratorium/ assessmentproject/florida/report.authcheckdam.pdf [https://perma.cc/T2ZZ-W47S].

339. Fla. R. CRim. P. 3.202(d).

340. Fla. Stat. Ann. \$ 922.052 (West, Westlaw through 2016 Second Reg. Sess.).

341. See Associated Press, California Supreme Court Halts Voter-Approved Death Penalty Measure, L.A. Times, (Dec. 20, 2016), http://www.latimes.com/local/lanow/la-me-ln-prop-66-death-penalty-halted20161220-story.html [https://perma.cc/ZV3N-CNFN] (describing one-page decision halting "all provisions" of Proposition 66, intended to expedite death penalty appeals). California has an enormous death row of almost 750 people, but it has not executed anyone since 2006, which has resulted in no more room for any newly condemned inmates-the subject of a recent constitutional challenge. See, e.g., Erik Eckholm \& John Schwartz, California Death Penalty System is Unconstitutional, N.Y. Times (July 16, 2014), http://www.nytimes.com/2014/07/17/us/california-death-penalty-unconstitutional-federal-judgesays.html [https://perma.cc/MH75-FFL5]; Paige St. John, California's Death Row, with No Executions in Sight, Runs Out of Room, L.A. Tımes (Mar. 30, 2015, 5:13 AM), http:/www.latimes.com/local/crime/ la-me-ff-death-row-20150330-story.html [https://perma.cc/2TBV-PLGR]. Indeed, much like in Virginia and North Carolina, death sentences have dramatically declined in Texas, which long led the nation in executions. There were just three death sentences in Texas in 2015. The story in Texas mirrors that in Virginia and North Carolina. There is a new RCD office that over time has grown to handle capital representation across most of the smaller counties in Texas that lack large public defender offices. Regional Public Defender for Capital Cases, Fiscal Year 2014 Summary (2014), http://rpdo.org/ 
decline along with Virginia, North Carolina, and Texas. Much of Florida's death row inmates were sentenced under a scheme that rendered the jury's vote, which needed not be unanimous, advisory, and in 2016, in Hurst v. Florida, the U.S. Supreme Court struck down that statute as violating the Sixth Amendment under its 2002 ruling in Ring v. Arizona. ${ }^{342}$ The impact of that ruling on Florida's death penalty may be felt for some years to come, as the Florida Supreme Court has already ruled that Hurst applies retroactive to the Ring ruling. ${ }^{343}$

\section{CONCLUSION}

Stephen Bright observed that in the years since he wrote his landmark article: "[t]he quality of defense lawyering is much better. . . Instead of just any local yokel who happens to have a bar card, it will now be somebody who has experience and is trained and knows how to investigate a case and put on mitigating evidence." ${ }^{344}$ Although homicide rates are gradually declining nationally, different states are experiencing dramatic drops in death sentences. In the scattered locales in which the death penalty remains, the experience in states like Virginia highlights the crucial importance of careful team-based defense work. In contrast, the federal courts, including the U.S. Supreme Court, have only gradually come to recognize the central importance of effective representation and adequate resources to investigate mitigation evidence. Although this has slowly changed, for years the Fourth Circuit routinely denied relief to Virginia capital defendants whose lawyers utterly failed to develop the same types of mitigation evidence that now routinely garners life sentences. Those decisions to deny relief on claims concerning the failure of lawyers to develop mitigation evidence are not based on validated empirical evidence about what actually impacts capital juries. ${ }^{345}$ Nor do they comport with the American Bar Association guidelines for what an adequate defense lawyer must do in a capital case. This is not only a Virginia problem: evidence suggests that most of those executed had significant functional deficits. ${ }^{346}$ Mitigation evidence is not "doubleedged" and it should not be viewed as "reasonable" for a lawyer to fail to

publications/FY14RPDOSummary.pdf [https://perma.cc/56ZD-9DKT]. Capital representation has improved, and death sentences have continued to decline across Texas. For a detailed account of the decline in Texas death sentences, see GARRETT, supra note 1, at ch. 4.

342. Hurst v. Florida, 136 S. Ct. 616, 624 (2016); Ring v. Arizona, 536 U.S. 584 (2002).

343. Mosley v. State, No. SC14-136, 2016 WL 7406506, at*25 (Fl. 2016) ("Defendants who were sentenced to death under Florida's former, unconstitutional capital sentencing scheme after Ring should not suffer due to the United States Supreme Court's fourteen-year delay in applying Ring to Florida.").

344. Mike Tolson, Fewer Killers Getting Sentenced to Death: Sharp Drop Seen Across the Nation, Including in Texas, Hous. Chron. (May 22, 2005, 5:30 AM), http://www.chron.com/news/nation-world/ article/Fewer-killers-getting-sentenced-to-death-1494687.php [https://perma.cc/NY44-RPR8].

345. Brandon L. Garrett, Validating the Right to Counsel, 70 WASH. \& LEE L. Rev. 927, 944-45 (2013)

346. Robert J. Smith, Sophie Cull \& Zoë Robinson, The Failure of Mitigation?, 65 Hastings L.J. 1221, 1253 (2014). 
pursue mitigation evidence - although deciding how to properly present such evidence does require real care and precision. ${ }^{347}$ In individual cases, judges must attend far more carefully to Sixth Amendment claims raising not only inadequacies of counsel during sentencing hearings, but also structural limitations on the role of counsel, such as if a lawyer lacked investigative resources, mitigation resources, and the type of team that the American Bar Association finds essential for the work that a capital case demands. Evidence as to the difference in outcomes when team-based lawyers represent capital defendants suggests that judges should scrutinize Sixth Amendment claims far more carefully. ${ }^{348}$ The evidence from this study suggests that the modern death penalty remains vulnerable to individual and systemic Sixth Amendment challengeswhere what remains of the death penalty persists chiefly in states that deny defendants consistent statewide capital trial representation.

Moreover, these findings also call into question whether statewide resources, to ensure consistency in representation, should be more routinely available in non-capital cases. Cases involving life without parole sentences or far less serious sentences may still require investigation of background and mitigation evidence, and too few public defenders or court-appointed lawyers have the resources to conduct such an investigation of their client outside of capital cases. If a team-based approach can make such a dramatic difference in death penalty cases, not only should statewide offices be funded in any death penalty state, but they should be funded in non-capital cases as well. It is a persistent Sixth Amendment problem that indigent defense is often left to county-bycounty funding, and crises or even collapse of public defender funding has become a recurring fact of life in American criminal justice. ${ }^{349}$ Systematic Sixth Amendment challenges to such funding failures can gain some support from the experience of capital defendants who have benefitted from statewide capital defender offices. ${ }^{350}$

Finally, the persistence of claims of innocence and the routine reliance on undocumented confessions, jailhouse informants, eyewitnesses, and non-DNA types of forensic evidence, should continue to give pause when considering the

347. This is not to say that defense attorneys do not have a real challenge in effectively presenting mitigating evidence so that jurors do not view it as double-edged; further, capital jurors may be skeptical of defense experts, and a nuanced presentation of mitigation evidence using both lay and expert witnesses may be essential. See Sundby, supra note 168, at 514, 519-22.

348. Systematic Sixth Amendment challenges to indigent defense resources at the county or state level have faced challenges in the courts although they have fared better in state courts. Brandon L. Garrett, Aggregation in Criminal Law, 95 CALIF. L. REv. 383, 401-04 (2007). For a proposal to enhance individual Sixth Amendment litigation, see Eve Brensike Primus, Structural Reform in Criminal Defense: Relocating Ineffective Assistance of Counsel Claims, 92 Cornell L. Rev. 679 (2007).

349. See Press Release, Am. Civil Liberties Union, ACLU Sues Over Public Defender Shortage and Resulting Wait List in New Orleans (Jan. 15, 2016) (describing litigation challenging current budget collapse affecting Louisiana public defenders).

350. For a discussion of the challenges of bringing systemic ineffective assistance of counsel litigation, see Garrett, supra note 348; for rulings in such cases, see for example, State v. Peart, 621 So.2d 780 (La. 1993). 
reliability of the death penalty. A surprising proportion of death penalty cases, even in the most recent Virginia capital trials, involved cases in which guilt was contested and claims of outright innocence were litigated. Time will tell whether any of those claims are ultimately found to have merit, but new evidence of innocence has surfaced often enough in the past, long after trial, that it is unlikely the innocence problem will go away.

This story of defense lawyering triumphant, not just at trial, but more importantly in cases plea bargained before trial, and a resulting retreat of the Virginia death penalty to only a handful of counties, should not be taken to mean that either Sixth Amendment litigation or better defense lawyering alone will "end" the death penalty-except perhaps in combination with other factors. Funding for indigent defense is rarely adequate or secure, and some state capital defenders have faced Draconian budget cuts. ${ }^{351}$ As Professor Scott Sundby has put it, "it seems unlikely that the death penalty will end simply because an unstoppable downward momentum towards fewer death sentences has developed." ${ }^{352}$ Because there were so few death sentences even in the 1980s and 1990s heyday, even small changes in the approaches of a few prosecutors, or new rulings by a few judges, or budget cuts to indigent defense in a few counties, can produce a rise in death sentences. The "tipping factors" on any given jury deciding whether to sentence to life or death may be far more delicate. ${ }^{353}$ Abolition may not result from more effective trial representation, but a narrower, geographically-dispersed, and far more fragile death penalty is the result.

So goes Virginia, so go states like North Carolina, Ohio, Texas, and perhaps over time, states like Florida. Even if competent lawyers increasingly represent capital defendants, the death penalty will continue to serve a purpose during plea negotiations. Far more murder convicts may receive higher quality investigators and lawyers and the enhanced procedures that come with death penalty litigation. Declining murder rates, if they do continue to decline in the long term, and softening public opinion, may continue to drive down death sentences nationally. Yet murder convicts continue to plead guilty to harsher sentences, including life without parole, to avoid the death penalty. Meanwhile, the role adequate representation can play suggests something still more unsettling about the far greater numbers of non-capital cases that do not receive the same legal resources.

351. See, e.g., Brenda Goodman, Official Quits in Georgia Public Defender Budget Dispute, N.Y. TIMES (Sept. 7, 2007), http://www.nytimes.com/2007/09/07/us/07georgia.html [https://perma.cc/75DKXAYP] (noting that nearly all death penalty cases in Georgia were "postponed" due to budget cuts to the new capital defender office, whose supervisor resigned noting that the budget provided was less than half of what it needed, while the caseload had doubled).

352. Scott E. Sundby, The Death Penalty's Future: Charting the Crosscurrents of Declining Death Sentences and the McVeigh Factor, 84 TEx. L. REv. 1929, 1932, 1934-35 (2006).

353. Id. at 1937. 
Not only is the modern death penalty highly vulnerable to Sixth Amendment challenges in the states in which it remains, but Eighth Amendment arguments regarding the arbitrariness of the death penalty will continue to be pressed. Since its 1972 ruling in Furman v. Georgia, the Supreme Court has grappled with what constitutes arbitrary death sentencing under the Eighth Amendment. ${ }^{354}$ In a range of recent decisions regarding particular types of death sentences, the Court has emphasized the number of jurisdictions imposing death sentences, and also the "rate of change," and "consistency of the direction of change." 355 Perhaps the courts will engage in more "data-driven arbitrariness review" in the future, focusing on the forces that have driven dramatic and consistent change in the composition of the entire death penalty. ${ }^{356}$ Such Eighth Amendment arguments will receive an audience before jurists like Justice Stephen Breyer, who are receptive to the empirical case that the wrongful conviction problem cannot be solved, lengthy delays before executions cannot be prevented, and geographic arbitrariness and racial discrimination will remain endemic. ${ }^{357}$ Although it is still too early to predict the imminent legal demise of the Virginia or the American death penalty, what remains is a far more scattered and arbitrary microcosm of what came before. Although de facto abolition may occur in practice far sooner than legal abolition, the shadow of the death penalty will continue to be cast over criminal justice long after the heyday of the death penalty has passed.

354. 408 U.S. 238 (1972) (per curiam).

355. Roper v. Simmons, 543 U.S. 551, 564-66 (2005).

356. See Smith, supra note 322, at 254.

357. See Glossip v. Gross, 135 S. Ct. 2726, 2755 (2015) (Breyer, J., dissenting). 
ApPEndiX A: Virginia Capital Trials 2005-2015

\begin{tabular}{|c|c|c|c|c|c|c|}
\hline $\begin{array}{c}\text { Name of } \\
\text { Defendant }\end{array}$ & Year & County & Sentence & $\begin{array}{l}\text { Length of } \\
\text { Guilt Phase } \\
\text { (days) }\end{array}$ & $\begin{array}{l}\text { Length of } \\
\text { Sentencing } \\
\text { (days) }\end{array}$ & $\begin{array}{l}\text { Jury Trial/ } \\
\text { Bench trial }\end{array}$ \\
\hline Andrews, Joshua & 2009 & Prince William & Death & 7 & 5 & Jury trial \\
\hline Carter, Ted & 2009 & Virginia Beach & Life & Pleaded guilty & 1 & Bench trial \\
\hline $\begin{array}{c}\text { Garret, Marcus } \\
\text { Valentino }\end{array}$ & 2008 & Virginia Beach & Life & Pleaded guilty & 3 & Bench trial \\
\hline Gleason, Robert & 2011 & Amherst & Death & Pleaded guilty & 5 & Bench trial \\
\hline Gray, Ricky Javon & 2006 & Richmond & Death & 2 & 2 & Jury trial \\
\hline $\begin{array}{c}\text { James, Jason } \\
\text { Andrew }\end{array}$ & 2007 & Henrico & Life & 2 & 1 & Bench trial \\
\hline Juniper, Anthony & 2005 & Norfolk & Death & 2 & 3 & Jury trial \\
\hline Justus, Berman & 2007 & Green & Life & 5 & 1 & Bench trial \\
\hline Lawlor, Mark E. & 2011 & Fairfax & Death & 5 & 11 & Jury trial \\
\hline Morgan, Xenia & 2005 & Halifax & Life & Pleaded guilty & 2 & Bench trial \\
\hline Morva, William & 2008 & Montgomery & Death & 6 & 2 & Jury trial \\
\hline $\begin{array}{l}\text { Padgett, Carey } \\
\text { Shane }\end{array}$ & 2014 & Roanoke & Life & Pleaded guilty & 8 & Bench trial \\
\hline Porter, Thomas & 2007 & Norfolk & Death & 5 & 4 & Jury trial \\
\hline Pricto, Alfredo & 2008 & Fairfax & Death & 7 & 9 & Jury trial \\
\hline Prieto, Alfredo & 2010 & Fairfax & Resentencing & $\mathrm{N} / \mathrm{A}$ & 13 & Jury trial \\
\hline Ragin, John Moses & 2014 & Newport News & Life & 10 & 2 & Jury trial \\
\hline Rogers, John "Jose" & 2006 & Stafford & Life & 9 & 3 & Jury trial \\
\hline $\begin{array}{l}\text { Shanklin, William } \\
\text { Solomon }\end{array}$ & 2007 & Hampton & Life & 4 & 1 & Jury trial \\
\hline Teleguz, Ivan & 2006 & Rockingham & Death & 4 & 1 & Jury trial \\
\hline Walton, Carl Lee & 2009 & Virginia Beach & Life & 2 & 2 & Bench trial \\
\hline $\begin{array}{l}\text { Whitten, Antwon } \\
\text { Giarrio }\end{array}$ & 2005 & Stafford & Life & 8 & 3 & Jury trial \\
\hline
\end{tabular}


APPEndix B: Twenty Virginia Capital Trials, 1994-2004

\begin{tabular}{|l|l|l|c|c|c|l|}
\hline \multicolumn{1}{|c|}{$\begin{array}{c}\text { Name of } \\
\text { Defendant }\end{array}$} & Year & \multicolumn{1}{|c|}{ County } & Sentence & $\begin{array}{c}\text { Length of } \\
\text { Guilt Phase }\end{array}$ & $\begin{array}{c}\text { Length of } \\
\text { Sentencing } \\
\text { Phase }\end{array}$ & $\begin{array}{c}\text { Jury Trial/ } \\
\text { Bench Trial }\end{array}$ \\
\hline Alaia, Enrico J. & 2001 & Chesterfield & Death & 3 & 1 & Jury trial \\
\hline $\begin{array}{c}\text { Akers, Thomas } \\
\text { Wayne }\end{array}$ & 1999 & Franklin & Death & Pleaded guilty & 1 & Bench trial \\
\hline Barnabei, Derek R. & 1996 & Norfolk & Death & 9 & 2 & Jury trial \\
\hline Bell, Edward & 2002 & Frederick & Death & 7 & 1 & Jury trial \\
\hline Cherrix, Brian L. & 1999 & Accomack & Death & 4 & 1 & Jury trial \\
\hline Elliott, Larry & 2004 & Prince William & Death & 7 & 3 & Jury trial \\
\hline Emmett, Christopher & 2002 & Danville & Death & 1 & 1 & Jury trial \\
\hline Green, Kevin & 2001 & Brunswick & Death & 1 & 1 & Jury trial \\
\hline Hedrick, Brandon & 1999 & Appomattox & Death & 3 & 2 & Jury trial \\
\hline Jackson, Jerry & 2004 & James City & Death & 5 & 2 & Jury trial \\
\hline Jackson, Kent & 2003 & King George & Death & 3 & 1 & Jury trial \\
\hline Lenz, Michael & 2003 & Augusta & Death & 1 & 2 & Jury trial \\
\hline Lewis, Teresa & 2004 & Pittsylvania & Death & Pleaded guilty & 1 & Bench trial \\
\hline Powell, Paul & 2004 & Prince William & Death & 1 & 1 & Jury trial \\
\hline Schmitt, John & 2001 & Chesterfield & Death & 5 & 2 & Jury trial \\
\hline Swisher, Bobby & 1998 & Augusta & Death & 3 & 2 & Jury trial \\
\hline Vinson, Dexter & 1999 & Portsmouth City & Death & 4 & 2 & Jury trial \\
\hline Walton, Percy & 1998 & Danville & Life & Pleaded guilty & 3 & Bench trial \\
\hline Williams, Marlon & 1996 & Chesapeake City & Death & Pleaded guilty & 1.5 & Bench trial \\
\hline Yarbrough, Robert & 1999 & Mecklenburg & Death & 1 & 2 & Jury trial \\
\hline
\end{tabular}

